Portland State University

PDXScholar

Dissertations and Theses

Dissertations and Theses

$1-1-1979$

\title{
The Portland Boundary Commission: a case study
}

Marvin James Price

Portland State University

Follow this and additional works at: https://pdxscholar.library.pdx.edu/open_access_etds Let us know how access to this document benefits you.

Recommended Citation

Price, Marvin James, "The Portland Boundary Commission: a case study" (1979). Dissertations and Theses. Paper 844.

https://doi.org/10.15760/etd.844

This Dissertation is brought to you for free and open access. It has been accepted for inclusion in Dissertations and Theses by an authorized administrator of PDXScholar. Please contact us if we can make this document more accessible: pdxscholar@pdx.edu. 
THE PORTLAND BOUNDARY COMMISSION: A CASE STUDY

by

MARVIN JAKES PRICE

A dissertation submitted in partial fulfillment of the requirements for the degree of

DOCTOR OF PHILOSOPHY

in

URBAN STUDIES

Portland State University

1979

(C) Marvin James Price 
TO THE OFFICE OF GRADUATE STUDIES AND RESEARCH:

The members of the Committee approve the dissertation of Marvin James Price presented February 14, 1979.

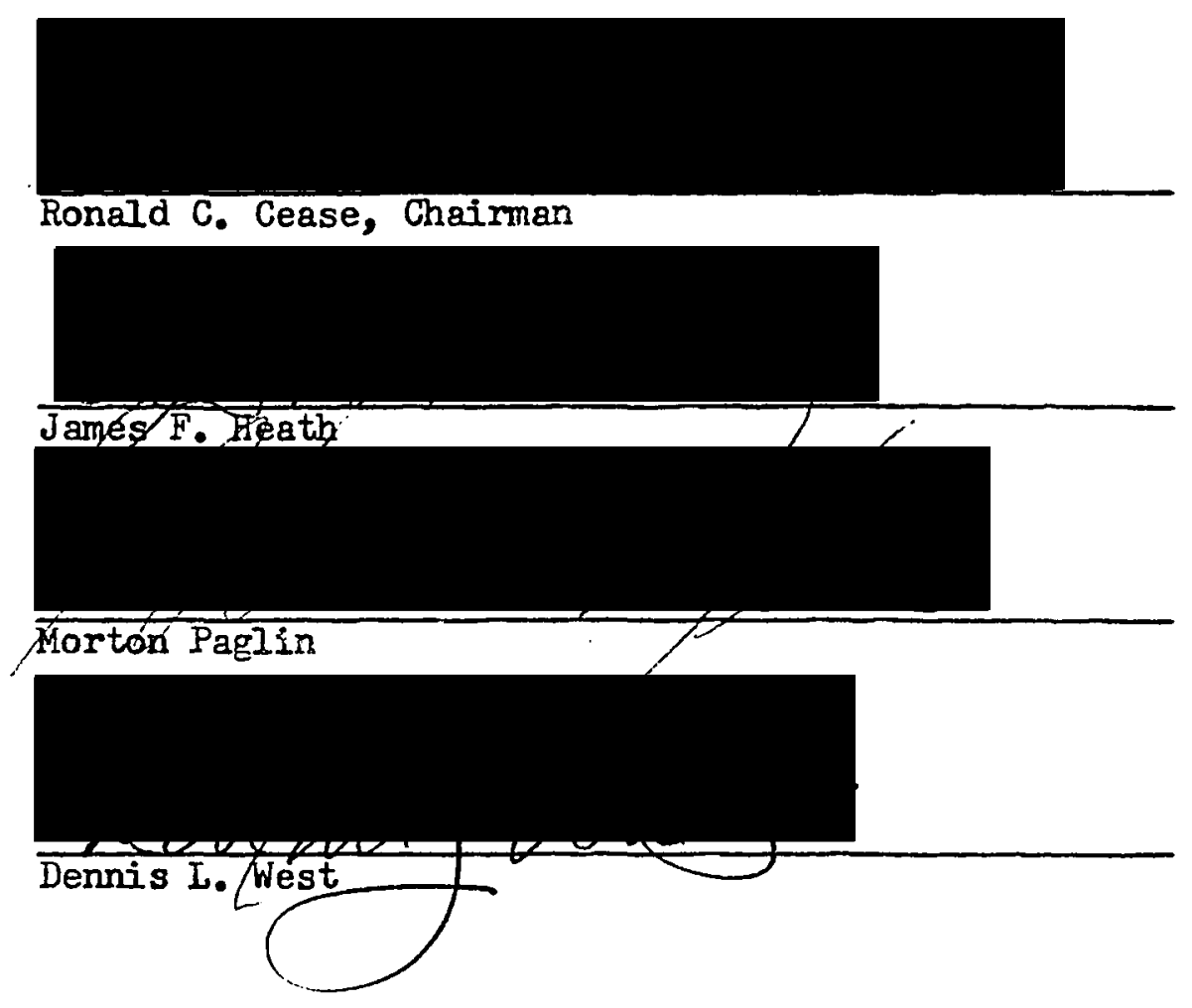

APPROVED:

Nohad A. Toulan, Dean, School of Urban Afalrs

Stânley. Rauch, Dean of Graduate Studies and Research 
AN ABSTRACT OF THE THESIS OF Marvin James Price for the Doctor of Philosophy in Urban Studies presented February 14, 1979.

Title: The Portland Boundary Commission: A Case Study

APPROVED BY MEMBERS OF THE DISSERTATION COMMITTEE:

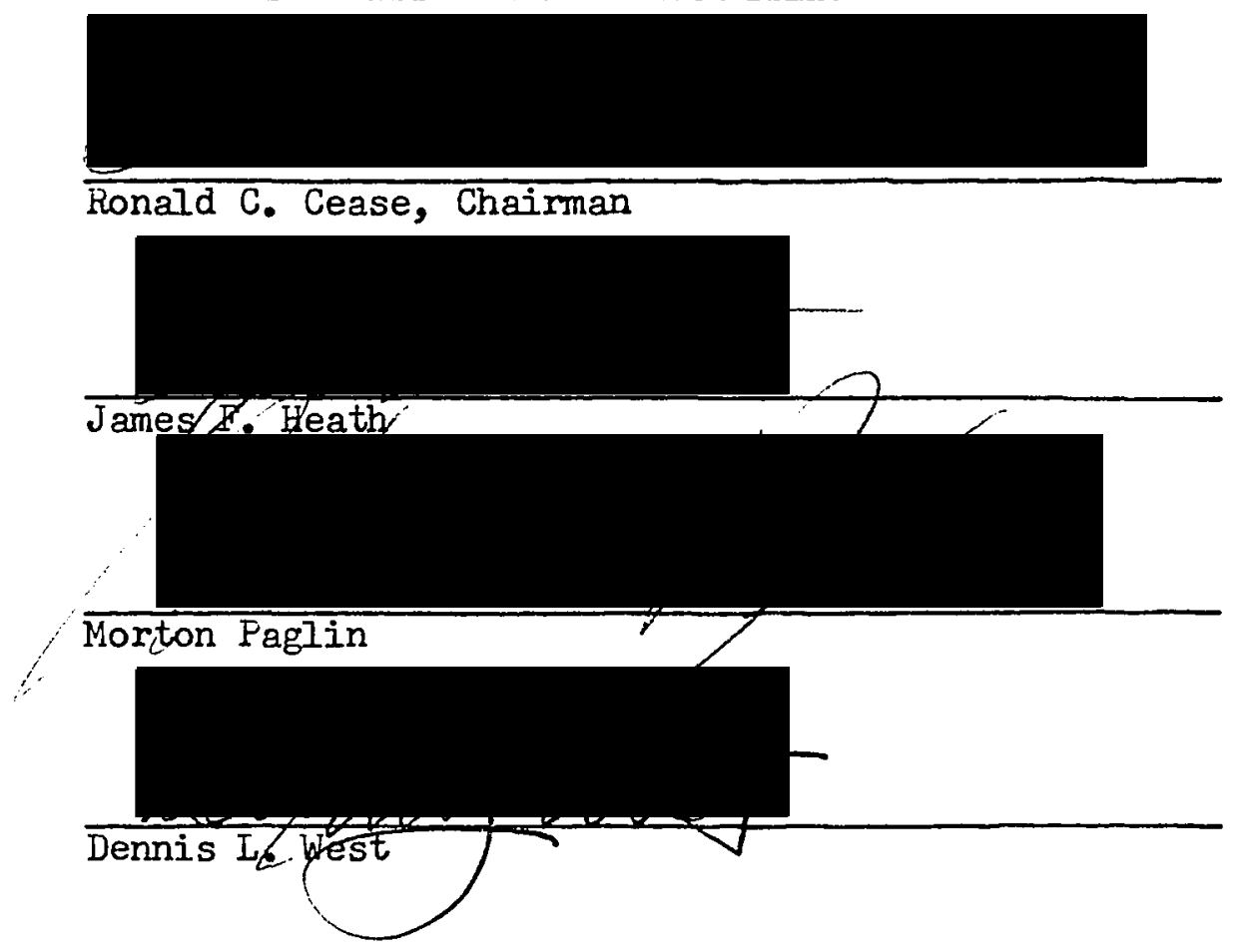

By the late 1960s, the literature of state and local government had been long dominated by what might now be termed a "traditional" approach, al though the "public choice" paradigm was challenging it successfully. Those who took the traditional approach saw America's metropolitan areas to be in a crisis state, to be suffering from a variety of social, cultural and economic ills which were making these areas virtually uninhabitable. Exacerbating these difficulties was a system of local governmental organization which the traditionalists 
characterized as fragmented, overlapping, and duplicative, a system incapable of providing an areawide governmental structure to respond to areawide problems.

A number of ameliorating steps to deal with this situation were recommended to the states by such institutions as the Advisory Commission on Intergovernmental Relations, The Council of State Governments, and the Committee for Economic Development. These included recommendations to establish state boundary review agencies to apply state policy to local government boundary changes. Oregon was one of a number of states to adopt these recommendations when in 1969, after a twelve year gestation period, it created local government boundary commissions in the Portland, Salem, and Eugene metropolitan areas.

This dissertation is an exploratory evaluation of the Portland Boundary Commission and hopefully makes a contribution to the meager body of knowledge on boundary commissions in Oregon. Data necessary to such purposes include published and unpublished materials from the Portland State University library; the joint Columbia Region Association of Governments-Portland Boundary Commission library; the flles of the former Tri-County Local Government Commission; the Bureau of Governmental Research, and others. The resources of the State of Oregon Archives, including minutes, tapes, exhibits, and reports of interim and regular committees were also utilized. A major source of information, of course, was the records of the Portland Boundary Commission. These included correspondence, tapes of public hearings, summarized minutes of public hearings and meetings, and files on each proposal (maps, staff reports, final orders, and other written 
materials). In addition, personal interviews were carried out with nearly all persons who have played important roles in all phases of the Commission's development and operation.

Findings and conclusions were reached with respect to a number of aspects of the Commission, including: the bill's development by locel institutions (the Portland Metropolitan Study Commission) and individuals (Ronald Cease, A. McKay Rich, Frank Roberts, John W. Anunsen, and others) and interim committees of the state legislature, and Legislative Counsel; the bill's legislative history and development, what factors affected the bill's passage and the major policy issues which concerned it; critical decisions made in the earliest stages of the Commission's operation with respect to leadership and staff; revisions in the Law made since the original statute became operative and how those changes related to Commission operations; the intergovernmental relations in which the Commission engages and case studies illustrating a taxonomy of those changes; the difficulties in the 1977 Legislature and an analysis of the structural and functional components of the Commission's political vilnerability which draws upon the work of the Joint Interim Task Force on Boundary Commissions and innexations; the relationships among the commissioners, their perceptions of the Commission's operation and the relationship between the Commission and its staff; and comments by the author on the general operation of the Commission, the major problems presently facing the Commission and some informed speculations and recommendations with respect to the functional and political future of the Commission. 


\section{ACKNOWLEDGMENTS}

Many people helped to make this dissertation possible. 'lhe searching and constmative criticisms of the dissertation committee members contributed heavily to improving its quality. The faults that remain are mine alone.

A. McKay Kich and John W. Anunsen devoted much of their valuable time guiding me along paths uncharted by written documents. Mrs. Keeler and others at the Oregon State Archives were most helpful to me in providing access to documents under their supervision. Don Carlson, Ken Martin, Jean Kretzer and the others on the Portland Boundary Commission staff were very helpful and gracious in their assistance. fill of the members of the Commission who gave me their time for interviews have my deepest appreciation.

A note of thanks is due the Political Science Department at Portland State University for providing valuable office space and assistance.

A special note of appreciation goes to my wife, Carla, who typed all of the drafts and contributed editorial assistance. 
PREFACE

The literature about American local government in the fifties and sixties focused heavily on the so called "metropolitan problem." According to those who perceived the condition of America's metropolitan areas as a problem, and most of the commentators on the subject who followed the "political reform tradition" paradigm did, the dramatic increases in the rates of urbanization and suburbanization in the late nineteenth and the first half of the twentieth century had broken apart the existing pattern of urban government and created the metropolitan problem. The fundamental components of the "political reform tradition" paradigm would include the following: (1) Political fragmentation leads to chaos; (2) Equal service levels are desirable area wide; (3) Complexity of governmental pattern of organization prevents citizen control; (4) Minimum size is necessary to achieve scale economies. The ideal institutional arrangement which these assumptions usually led to was consolidation. By mid-century, fragmentation, overlap, duplication, conflict, and inefficient delivery of urban services characterized urban government according to the traditional paradigm. Studies conducted in Oregon by legislative interim committees, the Bureau of Municipal Research at the University of Oregon, the Portland Metropolitan Study Commission and others followed the traditional paradigm and found that the same characteristics were inherent in Oregon's metropolitan areas. Both the national and local studies traced a portion of the cause of the social, cultural, and economic ills of the 
metropolitan areas to an inadequate pattern of local government organization. Not only was the pattern considered a partial cause, it was also thought to be a major impediment to remedial action. Taking 1 ts cues from the national literature and its own studies, the Oregon Legislature in 1969, after a long gestation period of twelve years, passed the Boundary Commission Law creating local government boundary commissions in the Portland, Salem and Eugene metropolitan areas. The creation of boundary revlew agencies had been recommended for several years in both the national and local literature as one of a number of actions that ought to be taken by the states to reform the pattern of local government organization in their metropolitan areas, as one step in dealing with the metropolitan problem. These boundary commissions were given review and regulatory powers over specified local governmentai boundary changes within Oregon's metropolitan areas, with the expectation that the commissions would play a major role in the cure and prevention of the metropolitan problem in Oregon.

This dissertation is an exploratory investigation and analysis of the operations of one of the three commissions: the Portland Boundary Commission. During their decade of operation, the Oregon commissions have not aroused much interest among local academic researchers and even less interest among the general public. Nor have boundary review agencies attracted much attention on a national basis, a very recent state and local government text; 80,000 Governments: The Politics of Sub-national America, 1978, does not mention boundary review agencies, al though the dominant theme of the book is the traditional metropolitan problem. This is not at all uncommon as a review of the recent state 
and local government literature would demonstrate. Nevertheless, the Oregon boundary commissions have been the subject of a few studies with the most recent study completed only a few months ago by the Bureau of Govermmental Research and Services at the University of Oregon. These studies have concentrated on such issues as the adequacy of the language of the Boundary Commission Law, the role of the commissions in growth mangement, and the impact of the commissions upon the pattern of local governments. This dissertation has a different focus and hopefully will make a contribution to the current body of knowledge on Oregon boundary commissions. While not overlooking any significant aspect of the Commission, the dissertation focuses upon the political aspects of the Portland Commission and attempts to shed light upon how it has carried on its functions; the dissertation is a study of the Commission's internal operation, its relationship to other units and agencies of government, and its legislative struggles, among other topics. It is believed that this political point of view, not focused upon in earlier studies, will make a contribution to a more comprehensive understanding of the Portland Commission.

The first two chapters present a brief history of the development of the Oregon Boundary Commission Law. These chapters focus upon the intellectual development of the traditional paradigm's metropolitan problem and the concept of "boundary review" as a partial solution to that problem as presented in the literature of the major national institutions concerned with the system and organization of local government in America, along with concomitant developments in Oregon by local institutions. At the national level, special attention is paid to the 
Iiterature of prestigious Institutions such as the Advisory Commission on Intergovernmental Relations, The Council of State Covernments, and the Committee For Economic Development. The work of the interim committees on local government of the Oregon legislature is also reviewed. While the traditional paradigm's description and definition of the metropolitan problem had taken place over a long period of time and in many places, the specific proposals for boundary review agencies came primarily from these institutional sources, and the major participants at the state level in Oregon were most influenced by these sources. The latter part of Chapter II presents the development of the Oregon boundary commissions as it took place in the Oregon legislature over a twelve year period. Particular attention is paid to the legislature's analysis of the types of boundary review agencies proposed and to the major policy issues upon which their relative merits were assessed, and to the influence of such institutions as the League of Oregon Cities, the Association of Oregon Counties, and the Portland Metropolitan Study Commission upon the boundary commission bill which finally became law.

Chapter III deals with the very brief period of time immediately following the establishment of the Portland Commission during which a number of decisions were made and actions taken which would powerfully influence the future operation of the Commission. Chapter IV covers the first three of the four leglslative sessions which have taken place since the establishment of the Commission. The major focus is upon changes in the Boundary Commission Law and how such changes were a response to difficulties encountered in the operations of the 
Commission under the original Law.

Because the Portland Boundary Commission is a new type of governmental institution, one of the more interesting aspects of its development and operation is its relationships with other units and agencies of government. The initial point from which the Portland Commission would begin to weave its place in the web of government was basically established by the Boundary Commission Law and the legislative history of the Law in Chapter II discusses this point. Nevertheless, the style and direction of the pattern has been at the discretion of the Commission. Chapter $V$ focuses upon the matrix of relationships in which the Commission is involved and does so on a functional basis by examining how the functions of the Commission are affected by the operation of other units and agencies of government, and, in turn, how the operations of the Commission affect the functioning of other units and agencies of government. 'Ihe chapter first presents a taxonomy of the Commission's relationships and then uses two case histories of actual proposals which have been before the Commission to illustrate how these relations manifest themselves in a "real world" context. At the end of the chapter is the metaphoric schematic which attempts to describe the major roles played by the Commission in a nonverbal format.

Chapters VI and VII together present a brief description of the formal legal powers of the Commission; the number and distribution-bytype of cases which have come before the Commission; and the type of analysis the staff performs on each proposal and the work load of the Commission. Summaries are provided concerning the change in the makeup of the system of local government in the Portland Commission's 
territory. Chapter VII discusses the universe of policy in which the Commission functions and discerns patterns of behavior created by the Commission in making its decisions on boundary changes. These patterns, concerning govermmental structure, land use, and provision of services, lend some meaning to the numbers presented in Chapter VI by explaining the basis on which the Commission changed the numbers the way it did. Chapter VIII deals with one of the most prominent features of the Portland Comission, its political vulnerability and instability, a characteristic it shares with the other boundary commissions in Oregon. This analysis centers around the 1977 legislative session, one which nearly resulted in the demise of the Commission, and looks to the structure and function of the Commission to explain its extraordinary political vulnerability. The work of a special Interim Task Force of the legislature which reviewed boundary commissions in preparation for action on the commissions during the 1979 session is examined. Unquestionably, the Task Force report is the opening shot in a promised legislative battle over the commissions in the next session.

Chapter IX ventures into the internal operation of the Portland Commission to examine the nature of formal and informal leadership; the personal and philosophical relations among the com tioners; the relationship between the Commission and its staff; the shaping of the Commission by exogenous events; and the commisstoners' views of the functional role of the Commission and how their role has changed over the period of time the Commission has been in operation. Special attention has been given to the manner in which the effective functions of the Commission have been influenced by the nature of its internal operations. 
TABLE OF CONTENTS

PAGE

ACKNOWLEDGMENTS .................

PREFACE . . . . . . . . . . . . . •

IIST OF TABLES $\ldots \ldots \cdot \ldots \cdot \ldots$

xi

IIST OF FIGURES ................

CHAPTER

I THE NATIONAL IITERATURE ..........

II THE LEGISLATIVE HISTORY .......... 18

III THE EARLY PERIOD ............... 41

IV THE COMMISSION AND THE LEGISLATURE . . . . . 55

V THE COMMISSION IN AN INTERGOVERNMENTAL CONTEXT •.

VI THE POWERS AND CASES ........... 113

VII PATTERNS AND POLICIES .................... 128

VIII THE COMMISSION IN STATE POLITICS ........ 141

IX THE COMMISSION AND THE STAFF ............ 166

X SUMMARY AND CONCLUSIONS . . . . . . . . . 192

BIBLIOGRAPHY $\ldots \ldots \ldots$

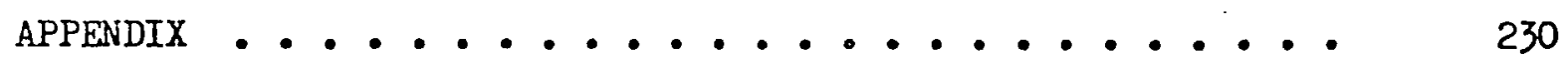




\section{LIST OF TABLES}

TABLE

PAGE

I Boundary Commission Bills Preceding Successful

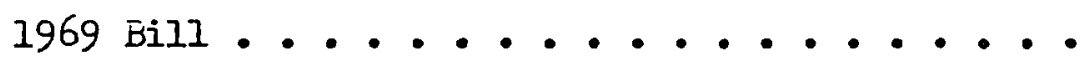

II Boundary Commission Bills in 1969 Session ......

III Types of Governments Under Boundary Commission Jurisdiction and the Principal Acts Under which They Operate . . . . . . . . . . .

IV Summary of Boundary Change Proposals Completed ...

V Yroposals by Type, Biennium and Action .......

VI Sewer and Water Proposals by Type, Biennium and Action ..................

VII Units of Government Within the Jurisdiction of the Portland Commission ........... 
LIST OF FIGUKES

ITGURE

PAGE

1. Boundary Commission Intergovernmental Relations

108 


\section{CHAPTER I}

\section{THE NATIONAL LITERATURE}

In 1969 the Oregon legislature passed and Governor McCall subsequently signed a law creating local government boundary commissions within the three major metropolitan areas in Oregon. The three areas were Columbia, Washington, Multnomah and Clackamas Counties, Marion and Prolk Counties, and Lane County. The law assigned to these commissions the responsibility to "provide a method for guiding the creation and growth of cities and special service districts in Oregon in order to prevent illogical extensions of local government boundaries and to assure adequate quality and quantity of public services and the financial integrity of each unit of local govermment." 1 "'he law provided the commissions the power to review the ".. - formation, merger, consolidation or dissolution of a city or district," ${ }^{2}$ and the " - annexation or withdrawal of territory to or from a city or district," 3 and to exercise a veto over such proposals. 4

All this was brought about, stated the statute, because "a fragmented approach has developed to public services provided by local government and such an approach has limited the orderly development and growth of Oregon's urban areas for the maximum interest of all its citizens," 5 and "The programs and growth of each unit of local government affect not only that particular unit but also the activities and programs of a variety of other units within each urban area, ${ }^{6}$ and 
therefore "as local programs become increasingly intergovermmental, the state has a responsibility to insure orderly determination and adjust ment of local boundaries to best meet the needs of the people." 7

The Oregon Boundary Commission Iaw was passed by the 1969 Legislature following a legislative gestation period of twelve years, during which abortive attempts were made in 1957, 1963, and 1967 to pass boundary review legislation. ${ }^{8}$ The legislative process can best be understood when placed within a cultural context. Therefore, it is instructive to examine the environment affecting those individuals and institutions which acted on these bills as they entered the legislative arena. One essential aspect of the environment is the literature. Prior to the turn of the century, local government in merica existed in neat and orderly arrangements with municipalities widely separated from one another and with clear lines of demarcation between incorporated cities and their surroundings. "It was this kind of urban settlement-self-contained, balanced, community conscious and widely separated-which was assumed by the American theory of city government. "9 Territorial expansion of the municipalities through the process of annexation had effectively adjusted geographic to population expansion. By the turn of the century, however, a number of factors began changing this happy scene into the "metropolitan problem" of the 1960s.

Foremost among these factors has been population, both in an aggregate sense of total population and, most importantly, in the shift of the distribution between urban and mural. Total United States population increased from $76,094,000$ in 1900 to $204,800,000$ in 1970 
while the percentage of the population classified as urban rose from approximately 45 per cent in 1910 to approximately 74 per cent in 1970. ${ }^{10}$ Rapid increases in the rate of urbanization swelled the populations of America's central cities and brought about an outward movement of the urbanized population from the areas within the boundaries of the municipal corporation-suburbanization. In the past, annexation had been an effective vehicle for extending the municipal boundary in order to incorporate the expanding urban population within. Now, however, the central cities were beginning to bump into existing municipalities where previously there had been intervening space and attempts to annex or consolidate the smaller into the larger were met with considerable resistance on the part of the suburbanites.

Like most conflicts in local politics, the struggle between the annexationists and the autonomists was resolved in the state capitol. As usually occurs in the triangular citysuburban-state relationship, the state legislatures were responsive to the suburbs and the cities were thwarted. Annexation was made more difficult in most states, particularly when incorporated municipalities were the target. Regulations governing incorporation were eased in many states, stimulating the creation of municipalities by suburbanites seeking to avoid annexation. 11

While the geographic advance of the municipalities was halted, the march of the urbanizing-suburbanizing population continued unabated and while armies may march on their stomach, urbanization and suburbanization march on a steady diet of essential urban services, most notably water, sewer, fire and police. Where no existing local government was able or willing to provide such services "special districts" were created and these have ".. spread with the swiftness of a brush fire. "i2 
'lhus, by the 1960s, the pattern of local government in metropolitan areas was typically a central city surrounded by small municipalities, townships, and counties, all of which would be interlaced by the boundaries of a multiplicity of special districts. This pattern of local government organization was seen quite differently by the two major competing schools of thought. The "public choice" or "polycentric" school characterized this pattern as an efficient result of the working of a market system in which people were making choices based upon, and in furtherance of, their own values.* The "political reform tradition" or "consolidationists" characterized the pattern varicusly as " . . a stack of pancakes in disarray . . ,"13 ". - a circus containing far more than the usual three rings . . , "14 " . . a crowded bus or subway . . , "15 " . . jungle-like in appearance. . . , "16 ". an illogical patchwork . . , "17 and simply, "bewildering."18

Those who took the "public choice" approach applied a set of assumptions common to economic analysis-methodological individualism, self-interest, and individual rationality in the use of scarce resources-to the study of the organization of state and local

* The following works would be considered major contributors to the development of the public choice paradigm. Robert A. Dahl and Charles E. Lindblom, Politics, Economics, and Welfare (New York: Harper \& Row, 1953); Anthony Downs, An Economic Theory of Democracy (New York: Harper \& Row, 1957); Vincent Ostrom, Charles Tiebout, and Kobert warren, "The Organization of Government in Metropolitan Areas: A Theoretical Inquiry." American Political Science Review, LV (December, 1961): 831-842; James M. Buchanan and Gordon Tullock, 'The Calculus of Consent (Ann Arbor: University of Michigan Press, 1962); Mancur 01son, Jr., The Logic of Collective Action: Fublic Goods and the Theory of Groups (Cambridge, Niass: Harvard University Press, 1965); hobert I. Bish, The Public Economy of Metropolitan Areas (Chicago: i. erkham, 1971). 
government activity. Their findings challenged both the assumptions of the "political reform tradition" and the prescriptions for metropolitan institutions which the traditionalists were recommending, primarily consolidation. The institutional arrangements which the public choice adherents indicated would be desirable were polycentric, as opposed to the monocentric preferences of the traditionalists. By the later half of the 1960s, the public choice approach constituted a mature body of theory capable of competing effectively with the political reform tradition in the marketplace of ideas.

The Boundary Commission Law, however, and the actors who were responsible for bringing it about were products of the political reform tradition. The policy section of the Law characterizes the condition of the organization of local government in terms which reflect the traditional analysis. Those people who played significant roles in creating the Boundary Commission Law were most heavily influenced by the literature being published at the time by the major institutions concerned with state and local government and intergovernmental relations; the Advisory Comnission on Intergovernmental Relations (ACIR); The Council of State Governments (CSG); and the Cormittee on Economic Development (CED), and these publications were dominated by the political reform tradition during the period in which the development of boundary commissions was taking place in Oregon: 1956 through 1969. while the public choice approach was a major influence in the general academic literature of state and local government by the later half of the 1960s, the effect of this approach on the institutions came later. Thus, the intellectual and philosophical heritage of the Boundary 
Commission Law and its authors is squarely in the political reform tradition. 'l'hus, the remainder of the chapter will illustrate the conception of the metropolitan problem from the political reform tradition perspective as it was presented in the institutional literature of the period. This should not be interpreted as a judgment on the relative merits of the two paradigms; it is simply a descriptive statement of the intellectual heritage of the Boundary Commission Law and its principal authors. As shall be pointed out more specifically later, the Boundary Commission Law may be limited by its dependence upon the traditional paradigm, but the Portland Boundary Commission as an institution and the role that it has played in the boundary change process has a value that is independent of the assumptions and biases of the traditional paradigm. The Boundary Commission can be seen as a thing of some beauty through either traditional or public choice colored glasses.

Kapid urbanization placed a great demand upon the ability of existing local governments to deliver public services such as water, sewer, fire, police, schools, transportation, parks and others and the delivery systems were found by the traditionalists to be wanting. To them the existing fragmented system of local government seemed unable to come to grips with these problems for a number of reasons. Proliferation of governments had brought about a concomitant proliferation of personalities and issues on which not even the most conscientious citizen could remain consistently well informed. As a result, participation in local politics diminished, bringing about a decline in the degree of public control and accountability over local government. 
Fragmentation of governments also fragmented the polity and the resulting compartmentalization prevented the development of an area-wide metropolitan consensus on problems which were area-wide in scope. "lhe fact that the metropolis is usually not controlled by the metropolitan public but by a nost of sub-publics is related to another serious consequence of governmental proliferation: the difficulty, indeed the common impossibility of arriving at a metropolitan consensus on areawide matters through formal political means. "19

The traditionalists believed that structural fragmentation led to conflicting programs wherein the individual local units tended to work in counterproductive rather than coordinated ways which reduced the aggregate positive effects of such programs, especially when they were directed toward problems considered area-wide in scope, and these usually consisted of capital intensive services with significant scale economies such as sewer and water. Another perceived effect of fragmentation on functional performance was the wide disparities between service needs and financial resources in different parts of the metropolis and the resulting deficiencies in those areas financially weak. "Generally speaking, the larger the number of indpendent govermmental jurisdictions within a metropolitan area, the more inequitable and difficult becomes the process of financing those governmental services which by their nature are area-wide in character." 20

Perhaps the most repeated argument of the traditionalists against the fragmented structure was its inability to deal with problems which were considered to be area-wide in scope and scale. As urbanologist Scott Greer explained, "The organization of the local polity in 
metropolitan communities has moved in a direction opposite that of other important segments of the society. 'Ihis has resulted in a violent disjuncture in scale between political organization and the aggregated results of economic organization-that is, between the political city and the socioeconomic city." 21 Thus, it was claimed to be a common society and a common economy in the metropolis with no common government. Earlier note was taken of a common polity with no common government. Thus, as social, economic and communitarian aspects of life took on a metropolitan area-wide context, political and governmental aspects did not. "The metropolitan problems are political problems: they demand binding public decisions on public issues, but the metropolitan complex shares no common government," 22 and "the peculiarity of 'the metropolitan problem' is that it is characteristically felt to be a problem requiring a governmental solution for which there is no readily available appropriate governmental machinery." 23 The traditionalists noted that problems arising from the social and economic interaction of the metropolis failed to respect the political boundaries that balkanized the metropolitan community. Almost every urban problem was defined by them as a metropolitan problem which could not be effectively resolved by a fragmented political system. The traditionalists believed if we removed the impediments to the expression and effectuation of the public interest through a reorganization of the fragmented polit1cal system, the metropolis would be governed in the interest of the whole rather than in the conflicting interests of its many parts. Luther Gulick explained succinctly that, "Once an indivisible problem is divided, nothing effective can be done about it." 24 Indeed, said 
the reformers, it was time to put Humpty Dumpty together again.

A near consensus existed in the body of literature emanating from the major institutions concerned with state and local government and intergovermmental relations: ACIR, CSG, and CED. State legislators and local study commissiors which looked to these sources had little difficulty discerning the direction in which they were pointing and the traditional model on which they were basing their conclusions and recummendations. In June, 1955, the United States Commission on Intergovernmental kelations in its Report to the President found that " . too many local governments, not enough local government - - ," 25 ". - bars an easy solution of the problem of the problem of achieving the decentralization of government . . , 26 and that ". - the states have the constitutional responsibility for the future development of local government . . ,"27 and pointed " . . to the need for a bolder use by the states of their powers over the incorporation, annexation, elimination, and consolidation of units in order to promote both efficiency and citizen participation in local affairs." 28 In 1956, the Council of State Governments in the States and the Metropolitan Problem reported that, Metropolitan areas in particular have an unsatisfactory pattern-a large number of units that represent an illogical patchwork of suppliers of services and regulations," 29 and found that, "public confusion, disinterest, and cynicism mount because of the time needed to watch over and control so many independent governmental operations is so large." 30 Central cities were described as being " . . completely hemmed in by other incorporated communities...," 31 and that many of these defensive incorporations 
were ". - lacking adequate services but lefally protected from annexation." 32 'Ihe proliferation of special districts was seen as a response to ".. the insufficiency of the general, traditional local units." 33 Vefensive incorporation and special district proliferation in the metropolitan fringe were warned against and it was suggested that "numerous states should review their incorporation laws to determine if the minimum population required for incorporation is too low . . , 34 because "the basis of the problem is the absence of general local governmental organizations broad enough to cope with metropolitan matters. Ihere is a lack of area-wide governmental jurisdiction that can plan and regulate and that are constructed to facilitate adequate accountability to the metropolitan public for their actions, "35 and the CSG placed the responsibility for taking remedial action squarely upon the states, " - . the states are the key to solving the complex difficulties that make up the general metropolitan problem." 36

Five years later in July, 1961, the Advisory Commission on Intergovermmental Relations published Governmental Structure, Organization and Planning in Metropolitan Areas and with respect to structure found that, "local governments in metropolitan areas present a bewildering pattern both because of their extreme numbers and their frequent overlapping." 37 The difficulty of annexation combined with the ease of incorporation was seen to lead to defensive incorporations. 38 The Commission also placed the remedial responsibility with the state: "Only the state has the power to halt the chaotic spread of small municipalities . . , "39 and made specific recommendations to the 
states which for the first time included a recommendation for an institutional structure to deal with the problem:

The Commission recommends that where such authority does not now exist, states enact legislation providing rigorous statutory standards for the establishment of new municipal corporation within the geographic boundaries of metropolitan areas and providing further for the administrative review and approval of such proposed new incorporations by the unit of state government concerned with responsibility for local government or metropolitan area affairs. 40

In June, 1962 the ACIR in its publication Alternative Approaches to Governmental Reorganization in Metropolitan Areas called for tightening controls over new incorporations in order to prevent " ... defensive incorporations contrary to orderly development of the area." 41 Immediately after this report came another by the iCIR in October, 1962 entitled State Constitutional and Statutory Restrictions Upon the

Structural, Functional, and Personnel Powers of Local Government, which reiterated findings which the Commission now termed to be a consensus:

Constitutions and statutes have created all kinds of local government and local reform efforts have been disappointing. Local government is fractionated and confusing. It is restricted territorially, financially, in structure and personnel, and sometimes directly in the functions authorized. Ad hoc agencies of great variety have arisen to perform functions which the traditional local units of government failed to perform. Small local units lack appropriate incentive to cooperate and no technique for combining them has been found. The power of decision is drifting to higher levels of government. The Commission believes a consensus exists that this situation is handicapping community development, is prejudicial to national strength, and might jeopardize our liberty. 42

In September, 1963 the ACIR in Performance of Urban Functions: Local and Area-wide said of the pattern of special districts, "These districts often are at best only a patch on the old framework." 43 By 1964, the ACIR in The Problem of Special Iistricts in American 
Government was recommending an institutional structure to deal with special districts much like that recommended for incorporation in 1961:

The Commission recommends that states enact legislation to provide that no special district be created prior to review and approval of the proposed district by a designated agency consisting of representatives of the county or counties and city or cities within the county or gounties within wich the proposed district will operate. 44

In 1966, the Committee for Economic Development. in Modernizing

Local Government recommended:

(1) The number of local governments in the United States, now about 80,000 should be reduced by at least 80 per cent. (2) The number of overlapping layers of local government found in most states should be severely curtailed . . . (3) The 50 state constitutions should be revamped-either by legislative amendment or through constitutional conventions concentrating on local government modernization to provide for boundary revisions, extensions of legal authority, and elimination of needless overlapping layers. 45

In addition, the Comittee called specifically for the establishment of boundary commissions, "Each state should create a boundary commission with continuing authority to design and redesign local jurisdictional lines, and to set time tables for consolidations and annexations. 146

The ACIR in its State Legislative Program, published each year, began in 1963 to propose state legislation on municipal annexation, reiterating the proposal each year thereafter. Beginning in 1967, the ACIR recommended legislation on municipal incorporation. These proposals would have established an Office of Municipal Incorporation Review and relaxed the regulations dealing with annexation of incorporated units. The Council of State Governments' publication, Suggested State Legislation, also published annually, contained essentially the same recomendations. 
By 1967, a number of states had changed their laws regarding annexation, incorporation, consolidation, and special district formation. Some had changed their statutes to achieve the purposes recommended in the tradi.tional literature, usually by creating zones around the existing cities in which any proposed new incorporation or special district formation would have to be approved by the existing city and by removing the necessity for concurrent majorities on annexations of unincorporated territory within the zone. These states included Arizona, Idaho, North Carolina, Nebraska, New Mexico, Georgia, Wyoming, Ohio and others. Some had created institutions to deal with the metropolitan problem and fragmentation. By 1963, the states of Alaska, California, Minnesota, and wisconsin had established administrative agencies or officials endowed with quasi-judicial powers to review proposed incorporations and annexations. While these institiutions differed in certain major ways, they did share certain characteristics: a commission as the usual form of organization; both municipal incorporations and annexations were within the purview of each of them and the flaska and Minnesota commissions also considered municipal consolidations while the California commissions considered non-school special district formation and extensions; in each case disapproval was final; and each review procedure included standards to be applied to each proposition before a decision was rendered. 47 An even earlier example of boundary determination was the "Virginia System" which used special ad hoc annexation courts made up of judges drawn from the state's judicial system to determine suits brought by municipalities seeking to extend their boundaries through annexation. This system had 
been in operation since 1904.

By 1967, the session in which the immediate predecessor to the ul timately successful bill was introduced in the Oregon legislature, much of the national literature of state and local government influencing the legislators was very favorably disposed toward the creation of such institutions. The literature published by the major institutions dealing with state and local government and intergovernmental relations also generally agreed upon the problem and its components; all were recommending the establishment of governmental structures to deal with the problems, and a number of states had recently established such agencies. In the period, 1967 to 1969, the favorable general environment was supplemented by the creation of an equally favorable local environment, the combination of which proved to be sufficient to gain passage of boundary commission legislation in the 1969 session. 
FOOTNOTES

1. ORS $199.410(2)$.

2. ORS 199.460(1), ORS 199.415(12).

3. ORS 199.460(1), ORS 199.415(3).

4. OKS $199.480(2)$.

5. OKS 199.410(a).

6. ORS $199.410(\mathrm{~b})$.

7. OHS $199.410(\mathrm{c})$.

8. H.8. 1721, Oregon Legislative Assembly, 1967 Regular Session. H.B. 1685, Oregon Legislative Assembly, 1963 R̈egular Session. H.B. 765, Oregon Legislative Assembly, 1957 Regular Session.

9. Luther H. Gulick, The Metropolitan Problem and American Ideas, (New York: Alfred A. Knopf, 1966), p. 55.

10. U.S., Department of Commerce, Bureau of the Census, Statistical Abstract of the United States: 1971, (92d edition) Washington, D.C., 1971.

11. Michael N. Danielson, Metropolitan Politics, (Boston and ioronto: Little, Brown and Company, 1966), p. 54 .

12. John C. Bollens and Henry J. Schmandt, The Metropolis, (New York: Harper \& Row, 1965), p. 159.

13. Ibid., p. 142.

14. The Council of State Governments, The States and the Metropolitan Problem, (Chicago: The Council of State Governments, 1956), p. 21.

1.5. Bollens and Schmandt, The Vietropolis, p. 142.

16. Ibid., p. 151 .

17. The Council of State Governments, The States and the lietropolitan Problem, p. I4l. 
18. Advisory Commission on Intergovernmental Relations, lovernmental Structure, Urganization and Planning in Metropolitan Areas, (Washington, D.C.: Government Printing Office, July 1961), p. 14.

19. Bollens and Schmandt, lhe Wetropolis, p. 178.

20. ACIR, Governmental Structure, p. 15.

21. Scott Greer, The Emerging City, (New York: The Free Press, 1962), p. 175 .

22. Ibid., p. 172 .

23. Norton C. Long, The Polity, (Chicago: Rand McNally \& Company, 1962), p. 156.

24. Gulick, The Metropolitan Problem, p. 24.

25. Ibid., p. 47 .

26. Advisory Commission on Intergovernmental Relations, Report to the President, (Washington, D.C.: Government Printing Office, June 1955), p. 47 .

27. Ibid., p. 49 .

28. Ibid., p. 49 .

29. Ibid., p. 141 .

30. Bollens and Schmandt, The Metropolis, p. 21.

31. Ibid., p. 30 .

32. Ibid., p. 39.

33. Ibid., p. 18.

34. Ibid., p. 138.

35. Ibid., p. 17 .

36. Ibid., p. 132 .

37. ACIK, Governmental Structure, p. 14.

38. CSG, The States and the Metropolitan Problem, p. 16.

39. Ibid., p. 39.

40. Ibid., p. 39. 
41. Advisory Commission on Intergovernmental Relations, Alternative Approaches to Governmental Reorganization in Metropolitan Areas, (Washington, D.C.: Govermment Printing Office, June, 1962), p. 11.

42. Advisory Commission on Intergovernmental Relations, State Constitutional and Statutory Restrictions Upon the Structural, Functional and Personnel Powers of Local Government, (Washington, D.C.: Government Printing Office, October, 1962), p. 3.

43. Advisory Commission on Intergovernmental Relations, Performance of Urban Functions: Local and Area-wide, (Washington, D.C.: Government Printing Office, September, 1963), p. 76.

44. Advisory Commission on Intergovernmental Relations, The Problem of Special Districts in American Government, (Washington, D.C.: Government Printing office, 1964), p. 18.

45. Committee for Economic Development, Modernizing Local Government, July, 1966, p. 18.

46. Ibid., p. 61.

47. Ronald C. Cease, A Report on State and Provincial Boundary heview Boards, The Portland Metropolitan Study Commission, Portland, August, 1968. 
CHAYTEK II

THE LEGISLATIVE HISTORY

In 1955 the Oregon Legislature passed Senate Joint Resolution 31 creating the Joint Legislative Interim Committee on Local Government.

The Comnittee was charged to "ascertain, study and analyze all facts relating to governmental relations between cities, counties and districts as these relationships have been affected and made more difficult and complex by reason of the great growth in population of Oregon and particularly the growth in population and development in the unincorporated urban areas of the counties. I The Committee considered its creation to be " . . a direct recognition of the state's responsibilities for providing an adequate system of local government. 2

Using language very much like that in national studies, the Committee found that Oregon's pattern of local government " . . has arrived - - without conscious direction, and consequently local government in this state is haphazard, uncoordinated, and fragmented." 3 The Committee observed that ". - maladjustments of local government function and area are characteristic of almost every urban area in the state, large or small." 4 In a summary statement, which the Committee felt strongly enough about to underline in its entirety for emphasis, the Committee identified the failings of local government organization in Oregon which had contributed to this state of affairs:

Specifically, the major shortcomings of local government organization have been the breakdown of city growth through annexation, the failure or inability of counties to take initiative in the resolution of suburban problems and the consequent creation of an unwieldy structuie of special district governments in the suburban areas. As a result, 
suburban areas can turn to no single overall unit of local government with general responsibility for the public health, safety and welfare. 5

The Committee expressed little faith in the ability of existing

organizations and processes to deal with these problems:

The Committee is convinced that basic changes are needed in local government organization in this state. Voluntary cooperation and use of existing procedures for annexation and consolidation could go a long way toward solving most suburban problems. However, use of voluntary cooperation and existing procedures for annexation and consolidation has not been frequent or extensive enough to solve them in the past, and there is no reason to believe that it would solve them in the future. The Committee believes that legislation and constitutional amendments necessary to provide a more adequate structure of local government organization for Oregon should be enacted. 6

Among the proposals exanined and rejected by the Committee were those which would deprive outside areas of the privilege of voting in annexation elections. 7

However, the Committee did feel that "the proposal that questions of annexation, as well as questions of incorporation, be submitted to an arbitration procedure must be considered in a different category. In this case, all interested parties would be afforded an opportunity to be heard, and the decision could be made impartially in accordance with legislatively prescribed standards. Evidence could be submitted which would bear directly on the question to be decided. In view of the heated irrationality with which many annexation elections are conducted, the arbitration proposa]. has some tempting features. The Committee rejects it, but commends it to the further attention and study of the legislature and the citizens of the state. 8

The report carried in its appendix an "IlIustrative Outline of a Plan for Arbitration of Annexation and Incorporation," which contained the creation of a Boundary Arbitration Board having statewide control over incorportation and annexation." This "Illustrative Outline," with a few changes, was introduced as H.B. 765 into the 1957 Legislature by Representative Keith Skelton of Eugene and can be considered the first 
bill intending to create a boundary review agency in Oregon.

I'he next major analysis of local government in Oregon by a legislative committee was set into motion by the passage of House Joint Resolution 23 by the 1961 Legislature, creating a Joint legislative Interim Committee on Local Government. 'The Committee in its report, Metropolitan and Urban Area Problems in Oregon, found that not much had changed since the work of its predecessor six years earlier. If anything, the problem had worsened:

As a result of the rapid increase in special service districts, the pattern of local government is one of overlapping jurisdictions; suburbia has mushroomed around 'core' cities, with duplication and inefficjency steadily becoming more widespread. After two decades of extensive urban growth, our units of local government are less capable of coping with local problems today than ever before.10

I'he Committee felt that "what is needed most for modernizing our sprawling urban settlements is not money, not cement, steel or labor. It is better governmental structure, "Il The Committee placed the preponderance of the responsibility for remedial action upon the State:

Thus, state government with its significant responsibilities, authority and financial resources, can make profound and constructive contributions to orderly urban development through the strengthening of local govemmental institutions. 12

The Committee made a number of specific proposals to the legislature, including a proposal to establish a metropolitan study commission in Portland and to allow the formation of study commissions in Eugene and Salem. ${ }^{13}$ The Committee did not recommend a boundary review agency, al though it did make proposals concerning annexation and incorporation law. However, in the 1963 session, a bill creating a boundary review agency was introduced by Representative Richard Kennedy of Eugene who had been the Executive Secretary of the Interim Committee. The 
bill, H.B. 1685, died in the House. 'Ihe situation of the 1963 bill was similar to the 1957 biII in that it was prepared by staff for inclusion in the report but failed to gain enough support within the Committee to be put forward as Interim Committee recommendations. However, the staff work did not go to waste as the legislation was introduced into the next. session in both cases, through other means. Legislation creating the metropolitan study commission was more successful and on November 8, 1963, the Portland Metropolitan Study Comission (HMSC) held its first meeting. while the legislation charged the Study Commission with the primary responsibility of studying and making recormendations on metropolitan government, the statute also allowed recommendations of legislation considered necessary to such ends. It was under the terms of this provision that the PMSC began a five year involvement with boundary review legislation in the process of which it would come to play a major role.

The PMSC took its initial action on boundary review on June 22, 1965 when the Executive Committee approved the appointment of a Review Board Committee. Original members of the Comnittee were: Hugh Mcliilvra, Richard Braman, Loyal Lang, Dorothy Lee and Donald Huffman. In August, 1965, the Committee forwarded its Final Report to the Executive Committee. 14 'the work of the Committee did not result in boundary review legislation directly supported by the Study Commission. However, as claimed in the Mnnual Report of the Portland Metropolitan Commission, 1970, its work constituted the preliminary drafts used by the sponsors of H.B. 172l, 1967, a bill to establish a boundary review agency. The House Local Government Committee and its chairman, 
Representative Yackwood, formally introduced the bill. However, the persons most responsible for initiating the introduction of the legislation were k. G. Bud Kyle, the Mayor of Tigard and the Chairman of the Columbia Region Association of Governments Board of Directors, and Kobert Logan, the City Manager of Tigard. They had been experiencing a number of difficulties with annexation in Tigard and felt that a boundary review agency would be helpful in such circumstances. They requested the House Local Government Committee to prepare a boundary review bill. Chairman Packwood agreed and Kepresentative Richard Kennedy, a Committee member, in concert with Packwood, Kyle, Logan, and Orval Etter prepared a bill. This proposal, except for the method of appointment, followed the outline in the 1965 Report of the Boundary Review Committee which itself had drawn heavily on H.B. 1685, 1963. The day after the introduction of H.B. 1721 on February 27, 1967, the House Local Government Committee, at the request of the League of Oregon Cities, introduced $\mathrm{H} . \mathrm{B} .1497$, a bill modeled after the Local Agency Formation Comissions in California. Even before the fate of these 1967 bills had been settled, the Study Commission decided to re-enter the boundary review arena, this time with the specific intent of directly sponsoring legislation in the 1969 session. $^{15}$ on February 28, 1967 , the day after the introduction of H.B. $172 \mathrm{l}$ and the same day that H.B. 1497 was introduced, the Boundary Review Committee began to consider the broad policy questions involved in boundary review. ${ }^{16}$ The Study Commission began its work even while the 1967 bills were still in progress because the lixecutive Director, A. McKay Rich, felt that neither of the bills (H.B. 1721 and H.B. 1497) had a realistic chance 
of passage and that the preliminary work would provide an informational base for testimony on the current bills should the Study Commission be asked for comment or to testify in public hearings. 17 Rich's prediction proved to be correct. H.B. 1497 fell victin to a single wellplaced legislative shot fired by Representative Kennedy in a meeting of the House Committee on Local Government on March 20, 1967. During a hearing on the bill, he pointed out that commissions encompassing only one county, with authority restricted to that county, would not solve any problems. He noted that in Oregon there are several cities with territory in more than one county and that it is precisely these metropolitan areas that have the greatest problems. It will be recalled that Representative Kennedy had prepared and introduced H.B. 1685, 1963, and took the major role in preparing H.B. 1721, 1967, both of which had provided for territorial jurisdictions greater than a single county. I'his argument apparently proved compelling since the records of the Committee do not show that H.B. 1497 was mentioned again. H.B. 1721 faired somewhat better--it passed the House and went to the Senate with the support of the Governor. Representative Packwood, in supportive testimony before the Senate State and Federal Affairs Committee on May 10, 1967, declared that he was also speaking on behalf of Governor McCall in support of the bill. On April 24, 1967, Rich had informed the Boundary Review Committee of the Study Commission that H.E. 1721 had passed the House on April 20 but was in trouble in the Senate because it contained a provision for a single majority on annexation elections. The requirement for concurrent majorities in such elections was critical to the questions of municipal expansion and defensive incorporation. The 
reformers saw the requirement as an obstacle to effective and efficient government reorganization, suburbanites saw the requirement for concurrent majorities as the main line of defense against city takeover and the destruction of rural life.

In a hearing before the Senate State and Federal. Affairs Committee on May 10, 1967, Representative Packwood, Chairman of the House Local Government Committee and major sponsor of the bill in the House, spoke to this issue at length and took the position that the current law created a veto power on the part of the area to be annexed and that such a system was faulty. This was the only hearing on the bill on the Senate side and the bill was still in Committee when the legislature adjourned.

'lable 1 presents a brief comparison of the bills which preceded the successful 1969 bill, H.B. 1027. As can be seen in the lable, the two early bills, H.B. 765, 1957, and H.B. 1685, 1963, were very much alike, although there were some important differences. Among the more important similarities were the provisions in each for: a single statewide agency and appointments to the agency by the governor. imong the most important differences was the scope of the boundary changes covered. H.B. 765 covered only annexation while H.B. 1685 included incorporation, merger, and consolidation as well as annexation. Another important difference concerned the finality of their decisionsH.B. 1685 made only disapprovals final while H. B. 765 made both approvals and disapprovals final. Both were subject to judicial review. Under H.B. 1685 an action reported favorably continued on under applicable law, whereas under $H . B .765$, a decision for annexation went into 
TABLE I

BOUNDARY COMMISSION BILLS PRECEUING SUCCESSFUL 1969 BIL

\begin{tabular}{|c|c|c|c|c|}
\hline & H.13. 1721 (1967) & H.11. 2497 (1967) & $11.33 .1085(1903)$ & 11.1\%. $765(1457)$ \\
\hline $\begin{array}{l}\text { Structuro } \\
\text { Number } \\
\text { Size } \\
\text { Deslgnation } \\
\text { Terms } \\
\text { Qualifications }\end{array}$ & $\begin{array}{c}3^{a} \\
\frac{7}{4} \text { Gov. }_{4} \text { City } \\
\text { Kestdent }^{\mathrm{d}}\end{array}$ & City, $\begin{array}{l}36 \\
5 \\
4 . e\end{array}$ & $\begin{array}{c}2 \\
5 \\
\text { Governor } \\
4 \\
. \quad\end{array}$ & $\begin{array}{c}1 \\
5 \\
\text { Governor } \\
4 \text { r, }\end{array}$ \\
\hline$\frac{\text { Jurdsdiction }}{\text { derritory }}$ & Metro & County ${ }^{1}$ & State & state \\
\hline $\begin{array}{l}\text { Units } \\
\text { Advi sory/lijnding }\end{array}$ & $\underset{\text { Hixod }}{\text { Clty, jp. }}$ & 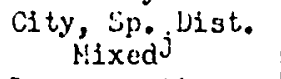 & ${ }_{\text {Mixedj }}^{\text {City, Sp. }}$ & $\begin{array}{l}\text { City, ip. llist. } \\
\text { Hindingk }\end{array}$ \\
\hline $\begin{array}{l}\text { Initiate } \\
\text { Hodify }\end{array}$ & $\begin{array}{l}\text { Incorporation } \\
\text { Herger } \\
\text { Corsolidation } \\
\text { Annexation } \\
\text { Yes } \\
\text { Yes }\end{array}$ & $\begin{array}{c}\text { Incorporation } \\
\text { Annexation } \\
\text { No } \\
\text { Yes }\end{array}$ & $\begin{array}{l}\text { Incorporation } \\
\text { Merier } \\
\text { Consolidation } \\
\text { Annexation } \\
\text { No } \\
\text { Yes }\end{array}$ & Annexation \\
\hline $\begin{array}{l}\text { l'rocedure } \\
\text { Rehenring } \\
\text { Rules \& Standards } \\
\text { Flnancirig } \\
\text { Staff }\end{array}$ & $\begin{array}{l}\text { No } \\
\text { Yes } \\
\text { County } \\
\text { Yes }\end{array}$ & $\begin{array}{l}\text { Yes } \\
\text { Yes } \\
\text { County } \\
\text { Yes }\end{array}$ & $\begin{array}{l}\text { No } \\
\text { Yes } \\
\text { State } \\
\text { Yes }\end{array}$ & $\begin{array}{l}\text { Yes } \\
\text { Yes } \\
\text { State } \\
\text { Yes }\end{array}$ \\
\hline
\end{tabular}

aovernor can cleate additional boundary boards in any county, or group of countics, upon recefpt of request f'rom county governing body or bodies and from governing body of most populous city or cities within county or counties.

bof the governor's four appointments, two must resicie in cities.

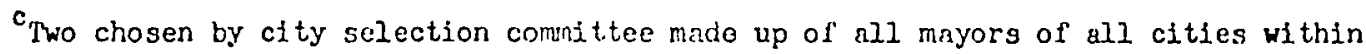
county, two by county court, one by those four persons.

$d_{A}$ member shall not be an employee or an elected public officer of a county or a municipal corporation at the time of this appointment or at any tine during his term.

Especifically provided that city or county officer may serve as a member of the Commission thile holding of fice as a city or county officer.

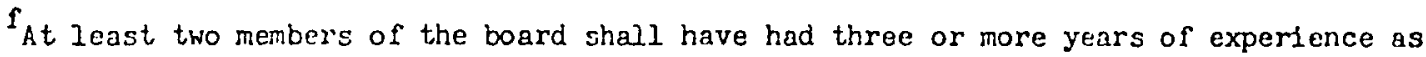
an official of a county or public or quasi-public corporation in this state and at least two members shall have had three or more years experience as an official of a city of this state.

grovided for temporary replacement for any member disqualifled. from a case because he realdes in or owns property in tise area to be annexed or the anroxing unlt.

${ }^{h}$ Created by specific county, three hoardi, one in each metropolitan area of the state generally known as fortland, Solem and Eugene and allowed creation of additional boards (see noto a).

${ }^{1}$ Crcates an agency in each of the state's thirty-six counties.

$J_{A l l}$ nerative findinfs are binding and final. Positive findings continue in accordance with applicable law.

$k_{A l l}$ findings are lingl and binding, subject to rehearing and court review. 
effect directly from the action of the agency after sixty days. This was subject to rehearing for thirty days and judicial appeal for ten days after and subject directly to judicial review for seventy days after the initial decision. The authors of these early bills were very heavily influenced by the systems then in operation in Virginia and Minnesota while the later bills appear to have been more heavily influenced by the systems in Alaska and California. 18 The later bills differed from each other and from the earlier bills. Both H.B. 1497, 1967, and H.B. 1721, 1967, provided for more than one commission. H.B. 1721 provided metropolitan jurisdiction in the three Standard Metropolitan Statistical Areas (SMSA) in the initial legislation, with provisions for additional commissions, and H.B. 1497 provided commissions for each individual county similar to the California Local Agency Formation Commissions. Another important difference was that H.B. 1497 specifically permitted county and city elected officials to serve on the commissions while H.B. 1721 specifically prohibited their serving on the commissions.

The development and passage of H.B. 1027 in 1969 occurred in three stages. The first stage consisted of the action of PMSC drafting a bill based on H.B. 172l, 1967. The second stage involved the modification of the PMSC bill by the Interim Committee on Local Government and its adoption as a Committee bill. The third stage consisted of review and revision of the Interim Committee bill by the House Local Government Committee, Joint Committee on Ways and Means, and the Senate Local Government Committee. While each stage had a somewhat different cast, a number of the players had a role in more than one of the stages and 
some played a role in all three. For example, the supporters of the legislation utilized the overlapping institutional memberships of individuals such as Frank Roberts and Hugh McGilvra to carry support for the legislation from stage to stage. While the number of unresolved policy questions confronting the players declined with each succeeding stage, the major sources of controversy were the same for each stage of the process, and the major source of disagreement-membership and appointment-dogged the bill to the drop of the curtain-final passage in the Senate.

It would not be inaccurate to say that H.B. 1027, 1969, rose from the ashes of H.B. 1721, 1967. the IMSC made a decision very early in the process to base its original draft on H.B. 1721, which, in turn, could trace its parentage at least partially to the work of the PMSC Boundary Review Committee in 1965.19 In developing the bill for submittal to the Interim Committee, the PMSC worked with representatives of the other important institutions dealing with local government affairs in an attempt to put together a proposal capable of generating widespread support before the Interim Committee. These included: Homer Chandler, Executive Director, Columbia Region Association of Governments (CRAG); Don Jones, Executive Secretary, League of Oregon Cities (LOC); and Jerry Orrick, Executive Secretary, Association of Oregon Counties $(\mathrm{AOC}) .20$ The Boundary Review Committee also authorized funds to hire Professor Ronald Cease of Portland State University to prepare a report and evaluation of boundary review agencies then in existence and to give the Committee his recommendations for boundary review in Oregon. 21 Dr. Cease had been the director of the Alaska Local Affairs Agency from 
1962 to 1966, an agency which was required by law to provide staff and support services to the Alaska Local Boundary Commission. 'Thus, one of' his responsibilities was to serve as Staff Director to the Commission. This first-hand experience gave him a great deal of credibility with both the Study Commission and the legislative committees. ${ }^{23}$ The dialogue involving the Boundary Review Committee, Cease, LOC, AOC, and CRAG covered a multitude of policy issues. Three, however, dominated the discussions: (I) Regional boards or a single statewide board; (2) membership eligibility; and (3) the appointive power. ${ }^{24}$ The first of these, the territorial question, had been fairly well settled by late April, 1968, with the LOC, AOC, and CRAG all in agreement on the desirability of regional boards. 25 The Boundary keview Committee and the Study Commission staff also preferred a regional arrangement and Cease strongly recommended such an approach. 26 The PMSC proposal to the Interim Committee had compromised the related questions: who serves?, who appoints?, by providing that appointment power would be shared among cities, counties and the governor. Appointive officials and employees of local government were specifically excluded from serving on the Commission, but the language did not apply to local elected officials. At this point in the process, the positions of the LOC, AOC and CRAG on the question of membership and appointment had neither hardened individually nor had these organizations reached a consensus. 27 Cease had recommended to the Committee that board members should not be local government officials. ${ }^{28}$ 'This opinion was also shared by the Study Commission staff, although it did not press the Study Commission to accept it because the staff felt it might antagonize those Commission 
members who were elected officials. The staff also felt that such an attempt might threaten the proposal itself with a loss of support from local government elected officials and their representatives. ${ }^{29}$

The second stage opened on June 7,1968 with a meeting of the Joint Interim Committee on Local Government at which time the PMSC presented its proposals on boundary review. After a review by Cease of boundary review agencies operating in other areas, Rich reviewed what he described as the second draft of a boundary review bill developed by the Boundary Review Committee, on a section-by-section basis. At the conclusion of this review, the Committee agreed unanimously to adopt a motion by Representative Roberts, who was also a member of the PMSC,

'That when another draft is prepared by the Metropolitan Study Commission that Legislative Counsel be consulted, and that time be given at the next Committee meeting to consider revisions in the draft and that Legislative Counsel confer with the Commission in order that an independent recommendation be made. 30

On June 11, Rich informed the Boundary Review Committee of a list of suggestions for improving the legislation which came from the June 7 meeting with the Interim Committee and indicated that the Interim Committee would consider the revised draft at its meeting July 12-13. On July 12, the Interim Committee discussed the revised draft with representatives of the Study Commission and made further recommendations which, along with some suggestions from Legislative Counsel were incorporated into a fourth draft by Orval Etter. On August 15, the Boundary Review Committee met, discussed and approved the revised draft and initiated a plan to meet with local legislators to solicit their support for the legislation. The plan was to have a number of commissioners meet with legislators from their respective counties during September 
and October, 1968. The Interim Committee met again on August 16 and reviewed the fourth draft. On this occasion, Cease, Jane Gearhart, and Representative Roberts provided the Committee with information and explanation. While the Committee made a number of changes, one was most significant. I'he Committee agreed to add elected local government officials to the categories of individuals who could not serve on a commission. The excluded categories already included local government appointed officials and employees. This action later rekindled an issue that had been somewhat controversial in the first stage: the role of elected local cfficials.

At the next meeting of the Interim Committee, Representative Anunsen and Jane Gearhart, who had assumed the drafting responsibilities from the PMSC committee, reviewed the bill section-by-section and then the Committee adopted the bill (ICC 192) as a Committee bill on a motion by Representative Anunsen. The vote: five aye, two nay, one not present, one excused. Representative Roberts assured the Committee that the two members not present, Senator Bain and Representative Kennedy, would support introduction of the bill. At its next meeting on October 11, the Committee voted six to two to introduce LCC 192 as a Committee bill.* After four months of deliberation, the Interim Committee had produced a bill which did not differ much from the bill originally subitted by the PMSC on June 7, 1968.

As Iable II demonstrates, the two proposals differed on only one significant point. This was the section dealing with appointive powers

* LCC 192 designation stands for consecutively numbered bill drafted by Legislative Counsel Comittee. 
TABLE II

BOUNDAKY COMMISSION BILLS IN 1969 SW'SSIUN

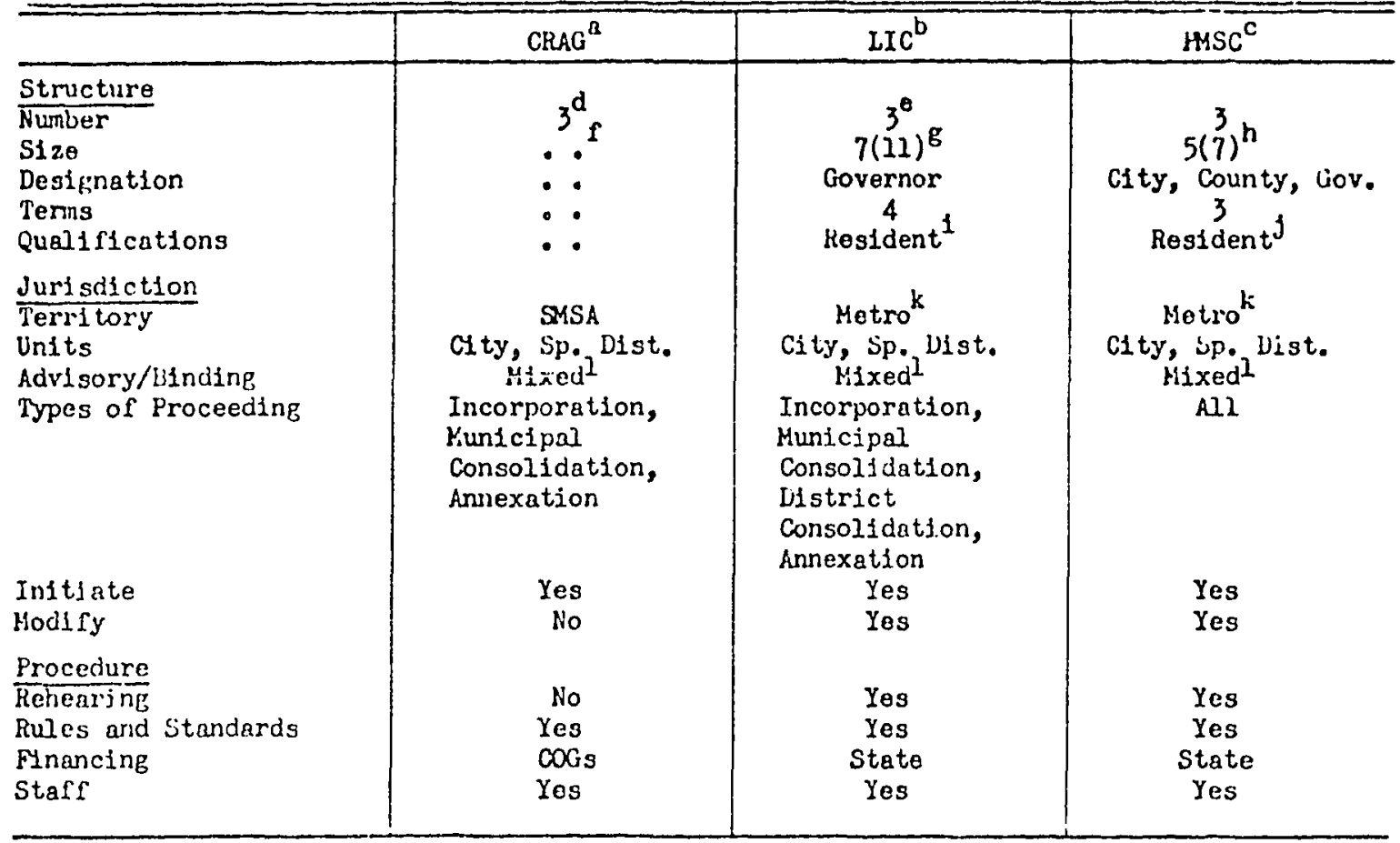

a Columbia Region Association of Governments.

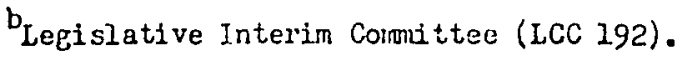

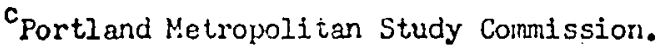

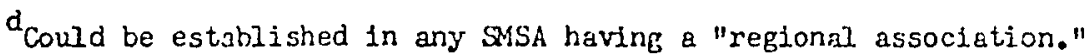

Any county or group of contiguous counties which so resolves or approves a popular petition to create a boundary commission.

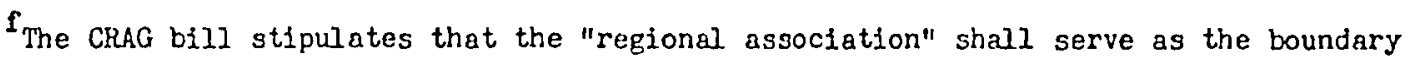
comission, however, it is not clear whether the entire general assembly will serve or if 1t. will delegate its authority.

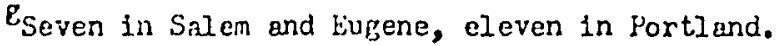

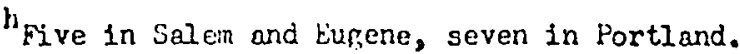

${ }^{1}$ blected officials, appointive officials and employees of government prohibited from serving.

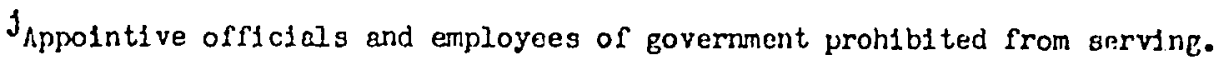

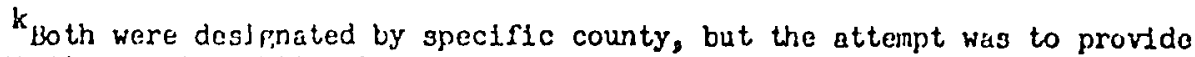
jurlsdictions metropolitan in scope.

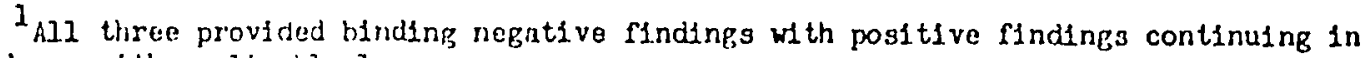
accordance with applicrible law. 
and membership. The original PMSC bill permitted elected officials to serve and dispensed the appointment powers among the cities, counties and the governor. ICC 192, the Interim Committee bill, specifically excluded elected officials from membership on the commission and placed all appointment powers with the governor.

These provisions in LCC 192 provided incentive for the development of an additional bill, known as the CRAG bill. This proposal was developed by Homer Chandler, the Executive Director of CRAG, and the CRAG Board. It designated the three Regional Councils of Government as boundary commissions, with elected officials serving as commissioners. On December 4, 1968, about two months after the Interim Committee had completed its work, a meeting called by Chandler was held in Eugene. Present were representatives of the three COGs, the LOC, AOC, the Governor's Office and a number of officials from other cities and counties. Also in attendance were two state legislators: Senator Husband, Chairman of the Interim Committee, and Representative fnunsen. Anunsen was the person most responsible for getting the boundary review issue a high priority in the Interim Committee's work. He also had undertaken the final drafting of the bill with Jane Gearhart of the Legislative Counsel and played the major role in getting the Committee to adopt it as a Committee bill. There was every reason to assume at that point that these legislators would continue to play important roles in the regular session. Records of the meeting make it clear that the purpose of the meeting was to attempt to persuade the crucial legislators to accept the CRAG bill, especially its provisions for service by elected officials. The attempt failed. Both Senator Husband 
and Representative Anunsen flatly declared that the decisions of the Interim Committee to bar elected officials and to give the appointive power to the governor were firm. The proposal to make the three colis boundary boards not only failed to convince Husband and Anunsen but it also failed to convince Wesley Howe of the Mid-Willamette Valley COG who stated that the CRAG bill was "totally unworkable as it applied to his council." 31 On December 27, Jones of the LOC, in a letter to Chandler of CRAG, put forward what he described as "being the minimum necessary to make the Iocal Covernment Interim Committee bill acceptable to the League, the Association of Counties, and the councils of governments in the Portland, Salem and Eugene areas." 32 Included was language placing elected officials on the Commission, but the mandatory creation of COG-based boundary boards was now limited to the Portland area, reflecting the lack of support for such a plan in Salem and Eugene. 'The third stage opened with the formal introduction of LCC 192 as H.B. 1027 on January 17, 1969 and referral to the House Local Government Committee. H.B. 1027 was one of thirteen bills from the Interim Committee, the other twelve being repeal bills relating to special districts. It should be noted that the preponderance of the work of the Interim Committee had been with special districts. Boundary review was clearly secondary. Senator Husband, the Chairman of the Interim Committee, was considered to have extraordinary interest in, and expertise on, the subject of special districts. The Committee held its first hearing on H.B. 1027 on January 29 when Cease made a presentation on boundary commissions generally and Jane Gearhart reviewed the Interim Committee bill section by section. At the next meeting, 
January 31, a set of amendments was offered by a consortium of the LOC, $A O C$, and the COGs which had been modified from those put forward by Jones a month earlier. The proposal to make the COGs boundary commissions had been dropped and the membership amendments now proposed that about half of each commission be appointed by the COGs from their members, who were elected officials, and the remainder to be lay persons nominated by the COGs and appointed by the governor. Again, they were not successful. They did, however, succeed in having a section added to the bill which would establish an elected official advisory committee to each boundary commission. These cormittees would meet on the call of the commission and would serve in advisory capacities only. The Portland commission has never utilized its advisory commission. On March 7, the Committee voted six to one to report the bill with a "do pass as amended" recommendation and Representative Anunsen was assigned to carry the bill on the floor. The bill passed easily by a vote of forty-nine to eight on March 17. Representative Anunsen reported that at the time he was surprised at the size and ease of the victory on the floor. 33

On March 19 the bill had its second reading in the Senate and was referred to the Joint Committee on Ways and Means which, in turn, assigned the bill to Subcommittee No. 1, chaired by Representative Hugh McGilvra. Chairman McGilvra was a member of the PMSC and had been the chairman of the Boundary Review Committee which developed the guidelines for boundary review reported to the PMSC Executive Committee in August, 1965. These guidelines had served as the basis for H.B. 1721, 1967. On the basis of this long and sympathetic association with boundary 
review legislation, Chairman McGilvra, in concert with Senator Stafford Hansell, Chairman of the Committee, had assured Kepresentative inunsen that money would be allocated in the budget to fund the commissions if the House passed the bill. 34 While the bill was in committee, Chairman McGilvra received a letter from Jones, dated April 2l, stating that the LOC could not accept the House-passed version and was withdrawing support from the bill. The letter again recommended that elected local officials be able to serve on the commissions and be able to appoint those members who would not be elected local officials. On May 2, the day the bill was reported out of Joint Ways and Means, Chairman McGilvra received another letter from Jones stating that,

At its meeting on April 29, 1969, the League of Oregon Cities' legislative committee voted to modify its previous position on H.B. 1027-the local government boundary commission bill. The Committee has some reservations about the impact of this legislation on existing city annexation programs but believes that other features warrant city official support of passage of the bill in its present form by the 1969 legislature. 35

With this action, those forces which had fought hard for a significant role for elected local officials "threw in the towel," secure in the thought that they had done their best and that there was always next year to attempt to amend the law if it proved necessary. 36 when Joint Ways and lieans reported the bill out on May 2, it was ordered "engrossed with amendments" and placed on the calendar for a third reading and final vote on May 7. This, however, did not take place at that time.

After the bill had been placed on the calendar, Senator Cornelius Bateson informed Representative Anunsen that he was concerned about the existing language in the bill with respect to taxation of withdrawn 
territory for its proportionate share of bonded or other indebtedness and implied that he would act to kill the bill if it were not amended to clarify the language in such a way as to retain the financial responsibility of the withdrawn territory. Representative Anunsen believed that Senator Bateson could, in fact, do as he threatened. 37 Because the rules of the Oregon legislature do not allow amendments on the floor, the bill would have to be taken off the calendar and returned to committee for amendment. On May 7, by a vote of seventeen to nine, the bill was removed from the calendar and referred to the Senate Local Govermment Committee where Senator Bateson, a committee member, added his amendments. 38 The bill was reported back on May 16 and was passed by the Senate on May 19. The vote on final passage was twenty-five, aye, none opposed, five excused. The difference between the vote to recommit and the vote on final passage demonstrated the effectiveness of the bill's lobbyists according to Bateson, who was the floor leader for the bill, because the nine votes against recommittal can be interpreted as votes against the bill. 39 On May 2l, the House concurred with the Senate amendments and repassed the bill forty-nine to six. On June 13, Governor McCall signed the bill which was to take effect on July I, 1969. Normally legislation does not take effect until ninety days after the end of the session. However, H.B. 1027 declared an emergency and established July 1, 1969 as its effective date.

It might be noted here that a thorough reading of the available documentation in conjunction with extensive interviews of the major participants provides a basis for a few generalizations about the legislative development of the Boundary Commission Law. Boundary commissions 
were an idea whose time had come. It had been long enough discussed that it was no longer perceived as a tirireai by conservative legislators and the lengthy analysis had improved the technical quality of the proposals. Because the House was organized by the Republicans and the Senate by a "conservative coalition," the bill's chance of passage was enhanced by the fact that its major proponent, Representative Anunsen, was a conservative Republican with recognized local government expertise. The bill was not strongly opposed nor a subject of great controversy. The controversy that did take place was not between the bill's supporters and opponents, but among the bill's supporters on the question of membership. The large majerities in both chambers reflected the not unusual situation wherein very few participants have any significant knowledge of the subject but are willing to support a bill if those whom they perceive as knowledgeable on the subject matter and responsible generally, are in support. At the time the bill was passed, not more than six of the ninety state legislators had significant knowledge of what the boundary commissions would do and how they would do it. 
HOOTNOTES

1. Findings and Recommendations of the Joint Legislative Interim Committee on Local Government, (Salem: November 30, 1956), p. 1.

2. Ibid., p. 1 .

3. Ibid., p. 127 .

4. Ibid., p. 17 .

5. Ibid., p. 14 .

6. Ibid., p. 125.

7. Ibid., p. 8 .

8. Ibid., p. 136 .

9. Ibid., p. 178 .

10. Metropolitan and Jrban Area Problems in Oregon, Report of the Legislative Interim Committee on Local Government, (Salem: January, 1963), p. 15 .

11. Ibid., p. 15.

12. Ibid., p. 31 .

13. Ibid., p. 35 .

14. Portland Metropolitan Study Commission, "Information Memorandum to Executive Committee from B. R. Committee," August 31, 1965, Salem, Oregon State Archives.

15. Portland Metropolitan Study Commission, "Memorandum of A. McKay Rich to B.R.C.," January 19, 1967, Salem, Oregon State Archives.

16. Portland Metropolitan Study Commission, "Minutes Boundary Review Committee," February 28, 1968, Salem, Oregon State Árchives.

17. A. McKay Rich, Private interview, Portland, October 21, 1977.

18. Orval Etter, Private interview via telephone, Portland and Eugene, December 14, 1977. Richard Kennedy, Private interview via telephone, Portland and Salem, January 5, 1978. 
19. Portland Metropolitan Study Commission, Memorandum to Boundary Review Committee from Robert G. Sampson," September 14, 1967, Salem, Oregon State Archives.

20. Portland Metropolitan Study Commission, "Minutes Boundary Review Committee," January 18, 1968, Salem, Oregon State Archives.

21. Ronald C. Cease, A Report on State and Provincial Boundary Review Boards, (Portland: The Portland Metropolitan Study Commission, 1968).

22. Ronald C. Cease and Jerome R. Saroff, The Metropolitan tixperience in Alaska, (New York: Praeger, 1968), p. 28, p. 447.

23. John $w$. Anunsen, Private interview via telephone, Portland and Salem, January 17, 1978. A. McKay Rich, Private interview, Portland, October 2l, 1977.

24. Portland Metropolitan Study Commission, "Minutes Boundary Review Committee," January 18, 1968, Salem, Oregon State Archives. Portland Metropolitan Study Commission, "Minutes Boundary Review Committee," February 1, 1968, Salem, Oregon State Archives.

25. Portland Metropolitan Study Commission, "Minutes Boundary Review Committee," April 23, 1968, Salem, Oregon State Archives.

26. Cease, Report, p. 4 .

27. Portland Metropolitan Study Commission, "Minutes Boundary Keview Committee," May 9, 1968, Salem, Oregon State Archives.

28. Cease, Report, p. 4 .

29. A. lick ay Rich, Private interview, Portland, October 21, 1977.

30. Oregon Legislature, Joint Legislative Interim Committee on Local Government, "Minutes," June 7, 1968, Salem, Oregon State Archives, p. 13.

31. Central Lane Flanning Council, "Minutes Boundary Review Board Meeting," December 4, 1968, Salem, Oregon State Árchives, p. 3.

32. Don Jones, Letter from Don Jones, Executive Secretary, League of Oregon Cities, to Homer Chandler, Director, Columbia Region Association of Governments, December 27, 1968, Salem, Oregon State Archives.

33. John W. Anunsen, Private interview via telephone, Portland and Salem, January 17, 1978.

34. Ibid. 
35. Don Jones, Letter from Don Jones, Executive Secretary, League of Oregon Cities, to Subcommittee No. I, Joint Committee on Ways and Means, May 2, 1969, Salem, Oregon State Archives.

36. Lon Jones, Private interview via telephone, Portland and Salem, January 18, 1978.

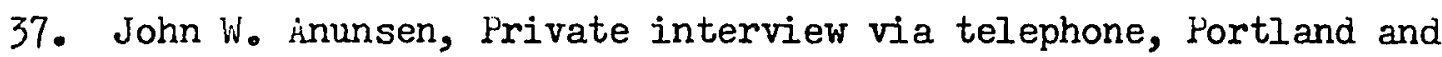
Salem, January 17, 1978.

38. Oregon Legislature, Senate Local Government Committee, "Minutes," May 13, 1969, Salem, Oregon State Archives.

39. Cormelius Bateson, Private interview via telephone, Portland and Salem, January 20, 1978. 
CHAPTEK III

THE EARLY PERIOD

Shortly after the Boundary Commission Law took effect on July 1 , 1969, a meeting was held in the Portland Metropolitan Study Commission's office in Portland at the call of Hobert Logan, Jirector of the State Local Government Relations Division (IGRD), for the purpose of developing a final suggested list of commission nominees to be sent to the Governor. In attendance, in addition to Logan, were Don Carlson, Assistant Director of the Portland Metropolitan Study Commission (MMSC); A. Mckay Rich, Director of PMSC; Dr. Ronald Cease; Eldon Hout, Washington County Commissioner and member of the Columbia Region Association of Governments Executive Board; members of the MMSC; and a number of local government officials. Prior to the meeting, lists of suggestions had been solicited from interested parties, such as the Chamber of Commerce and the League of Women Voters. At the meeting, these lists were compared and those names which occurred on a number of lists, and appeared therefore to be consensus choices, were put on the final list of recommendations sent to the Governor. No documents exist from the meeting. Information on the meeting came from interviews with A. McKay Rich, Don Carlson, and Ronald Cease and written correspondence with Hobert Logan. Another recommendation was that the appointments be geographically apportioned on the following basis: one member from Columbia County; two each from washington and Clackamas Counties; one 
from eastern Multnomah County; and five from the City of Portland. Senator Atiyeh had raised the issue of geograhic distribution in reference to a multicounty commission in the 1968 Interim Committee but the discussion led to no action. ${ }^{1}$ Ine Governor's Office accepted the geographic apportionment recommendation, though the law did not require any such distribution. The Governor appointed five members to the Portland Commission from the list: Dr. Brock Dixon; Marilyn Gunsul; Charles McKinley; Kichard Brown; and Dr. Ronald Cease. All had been actively involved in local governmental affairs in the Hortland area. The other six appointments were not taken from the list. Ionovan Blair and Mrs. Carl Brandenfels had been active McCall workers.* John Crawford and Campbell Richardson were suggested by members of the Governor's staff. Lou Lavacheck and Dr. Slominski were suggested by officials of suburban cities. The appointees were officially sworn at the first meeting of the Portland Boundary Commission on July 9, 1969. In addition to the commissioners, a number of people who had played important roles in bringing the Commission about and who intended to continue to be directly involved in the Commission's operations attended the first meeting of the Commission. These included Homer Chandler, Director of the Columbia Region issociation of Governments (CKAG); A. Nickay Rich of PMSC; and Robert Logan of LGRD. Hiter the swearing, straws were drawn to determine the length of the original term each commissioner would serve. The Boundary Commission Law provided

* Nowhere did the author find Mrs. Carl Brandenfels referred to by her given name. Therefore, the author will assume that Mrs. Carl Brandenfels is the desired form. 
that the terms of the original appointees be arranged to make subsequent turnover of the membership take place in a staggered sequence and not disturb the Commission's operation as would simultaneous terms:

Notwithstanding ORS 199.440 of the first appointees to a commission formed under ORS 199.430, one shall serve for one year, two for two years, two for three years and two for four years. 'the respective terms of the first appointees shall be determined by lot at the first meeting of the commission. 2

As a result, Cease and Mirs. Brandenfels drew one year terms; Richardson, Brown and Blair two years; Lavacheck, Crawford and Gunsul three years; and Slominski, Dixon and McKinley four years.

After receiving a list of the Governor's appointees, but before this first meeting, Rich had contacted Marilyn Gunul and arranged with her that she nominate Cease to be chairman of the Commission. Kich, who had been very actively involved in the development of the Boundary Commission Law, felt that it was important that Cease be elected chairman because his experience and expertise would be essential in getting the Portland Commission off to a proper start. Rich was acquainted with Marilyn Gunsul through her work at the League of women Voters and elsewhere, and did not feel abashed at making such a request of her. ${ }^{3}$ There was little doubt in the minds of either of them that Cease would be elected if nominated, especially if nominated first, and they did not want to leave the nomination to chance. Immediately after the drawing of straws, Marilyn Gunsul nominated Cease to be chairman of the Commission. There was, however, some objection to electing a permanent chairman at that point, as it had not yet been determined what the offices of the Commission would be or how long they would serve; nor had any other aspect of the formal leadership been determined. It was, 
however, recognized that these determinations would themselves require some degree of leadership and organization and a suggestion was made that a temporary chairman be elected and Cease was so elected. After the election, Robert Logan of the LGRD made a presentation to the commissioners in which he provided them with background information and an agenda which they would have to follow under the Boundary Commission Law. He first pointed out to the Commission that a tentative budget of $\$ 77,000$ had been allocated to the Portland Commission by the Emergency Board to fund the Commission through the current biennium. The remainder of the $\$ 175,000$ appropriation had been allocated to the Eugene and Salem Commissions. In response to a question from the Chairman, Logan noted that no monies could be expended or obligated by the Commission to hire personnel or for any other purpose, until the budget had been prepared, adopted, and approved. He informed the Commission that the Emergency Board was scheduled to meet on August 14 and 15 and that proposed budgets had to be submitted to the Emergency Board three weeks before the meeting. Because of the very short period of time remaining until the date three weeks before the meeting and the necessity of securing a legal budget before taking other kinds of necessary actions, Logan suggested that the preparation and adoption of a budget should be the Commission's highest priority.

Logan next informed the Commission that the Marion-Polk Commission had already had its first meeting and had decided to appoint three committees to carry out the functions necessary to set the Commission in operation. Míarion-Polk had appointed a Nominating Committee, a Rules and Procedures Committee, and a Budget and Personnel Committee. In 
addition to legal requirements necessitating a budget before disbursement, the Boundary Commission Law mandated the commissions to formally adopt, rules and procedures and provided that these must be legally in place before the Commission could take any action on boundary changes: "A commission shall adopt, and may from time to time amend, rules to govern the proceedings before the commission." 4 The Law also required that a public hearing must be held on the proposed rules and stipulated that mules could not take effect until at least 30 days after adoption: "A rule or an amenoment to a rule shall not take effect unless the commission first holds at least one public hearing regarding the rule or amendment." 5 "A rule or an amendment to a rule shall take effect 30 days after it is adopted by the commission unless a later date is provided by the commission in the order adopting the rule." ${ }^{6}$ This requirement placed another very serious time constraint on the newly developing Commission. All boundary changes initiated after July 1 , 1969 which fell under the Commission's jurisdiction, would be subject to Commission review. The Boundary Commission Law, at that time, allowed the Commission only 60 days to act on a "major boundary change" which was defined as " . . formation, merger, consolidation or dissolution of a city or district." 7 Thus, it was necessary that the rules and procedures development process take place as quickly as possible so that the Commission could review within the allowable 60 days any "major boundary changes" which might be initiated during this early period.

Logan also discussed the action the Marion-Polk Commission had taken with respect to staffing and informed the Portland Commission that 
the Marion-Polk Commission had decided to staff separately from the local council of governments. The question of who would supply staff to the Portland Boundary Commission had been a contentious one since the latter stages of the Boundary Commission Law's legislative development. Homer Chandler, Executive Director of CRAG, and the CRAG Board of Directors, wanted very much to supply staff to the Portland Boundary Commission and, partly for that reason, had supported LCC 192 after the CRAG bill died. Chandler and the Board apparently felt that staffing the Commission would give them some influence over its operation and also add to CRAG's functional role as an institution. Chandler developed a formal proposal to staff the Commission which he presented to the Commission at this first meeting. Others, particularly Cease, were strongly opposed to any arrangement other than an independent staff. Dr. Cease in his Report on State and Provincial Boundary Review Boards which he had prepared under contract with PMSC, strongly recommended that the commissions develop their own staffs:

Review boards should not be forced to rely on other bodies for basic staff assistance. With their own staffs, review boards can be sure, over time, of staff availability, staff loyalty, and staff continuity. The technical nature of local boundary problems requires a staff with high competence. This is not likely to be developed except within a special separate $\operatorname{staff.} 8$

In the footnote to the above section, he stated: "Unfortunately, it is not uncommon for legislatures to establish boundary review boards and require them to exist on the personnel of other public bodies. These bodies are crippled before they start." 9

A. McKay Rich of the PMSC also strongly favored an independent staff. His reasoning was that, after pushing for boundary commissions 
partly on the basis that they represented independent third parties capable of applying objective judgment to issues which in the past had been subject to the vagaries of local government parochialisms, it would be foolish to have such an institution dependent upon, or too intimately involved with, any other unit of government. He felt this would be the case if CRAG or any other institution provided staff. ${ }^{10}$ No action was taken on the CRAG proposal.

Having discussed briefly these three issues with which the Commission would have to deal immediately, it was decided the pattern set by the Marion-Polk Commission would be followed and Temporary Chairman Cease appointed the following committees: Nominating Committee, Brock Vixon Chairman; Rules and Procedures Committee, Campbell Richardson Chairman; and Budget and Personnel Committee, Marilyn Gunsel Chairman. All of the members of the Commission were appointed to one of the committees, but Cease appointed as chairmen those members who had special competence in the subject matter for which the committee would be responsible. He chose other cormittee members for similar reasons. Brock Dixon, Chairman of the Nominating Committee, had been a colleague of Cease at Portland State College, and Cease knew him to be experienced in personnel matters. Campbell Richardson was named Chairman of the Rules and Procedures Committee because he was a lawyer and Cease felt he would have some familiarity with rules and procedures development for such a quasi-judicial commission. Another appointee to this committee, Mrs. Carl Brandenfels, was also a lawyer. Cease appointed Marilyn Gunsul as Chairman of the Budget and Personnel Committee because he knew she had worked in the development of the 
Boundary Commission Law with the League of Women Voters and the Chamber of Commerce and leaned philosophically toward an independent staff. John Crawford was appointed to this committee to deal with the budget side because he was an accountant. Of all those appointed to the committees by Cease, only Marilyn Gunsul was appointed to a specific position because she was perceived by Cease as holding a particular position on a controversial issue. ${ }^{11}$ The remaining appointments were largely based upon personal expertise and committee responsibilities. As the committees began their work, they faced a blank slate bordered only by the mandates of the Boundary Commission Law which set some guidelines but left much discretion to the commissions. For example, with respect to staff, the Boundary Commission Law states: "A commission may employ administrative, clerical, and technical assistants for carrying on its functions and it may fix their compensation." 12

The second meeting of the Portland Boundary Commission was held the following week on July 16, at which time the committees made their initial presentations. In the case of the Nominating Committee, it was both the initial and terminal presentation. The official minutes of the meeting provide the following description:

Mr. Brock Dixon, Chairman of the Nominating Committee, presented the committee recommendations to the Commission. The committee proposes two officers, a Chairman and Vice Chairman, who will serve for a one-year term from July to July. There should be an annual election of officers with no prohibition on re-election of officers. By unanimous vote, committee recommendations were accepted and Ronald $\mathrm{C}$. Cease was elected Chairman and Mrs. Carl Brandenfels was elected Vice Chairman of the Commission.13

It appears from subsequent discussions with the participants that the report of the Nominating Comittee and the election of Cease and 
Mrs. Brandenfels were as noncontroversial as the minutes record it as being. By that time, everyone on the Commission was familiar with the role that Cease had played in the development of the Commission and believed that he was well qualified by his experience to lead the Commission.

The minutes of the Budget and Personnel Committee report is equally enigmatic and pallid, but, in this case, it is true that the subject matter contained the seeds of discontent because some members of the Commission did have strong feelings about the outcome, most notably the Chairman:

Mrs. Brooks Gunsul, Chairman of the Budget and Personnel Committee, advised it was the committee's recominendation that the Commission function as an independent agency employing its own staff, in view of the legislative intent and also to eliminate possible conflicts of administrative responsibility. 14

Cease's perceptions of Marilyn Gunsul's feelings on this issue had been accurate. Marilyn Gunsul, as a result of her research and study of boundary commissions while a member of the League of Women Voters and the Metropolitan Legislation Committee of the Chamber of Commerce, had strong personal preferences for an independent staff, and she carried the Committee with her. 15

Those who favored an independent staff did not necessarily bear malice toward CRAG, its leadership, or the ability of its staff. Their support ior an independent staff was based primarily upon their belief that the credibility of the Commission would, to a great extent, be a function of the independence of its staff. John Crawford, the accountant, gave the Conmittee's report on a proposed budget which requested $\$ 77,889$ for the biennium, a figure within $\$ 889$ of the target 
figure discussed by Robert Logan at the Commission's first meeting. Both the recommendations on budget and personnel were adopted unanimously. At the request of the Committee, Logan, who was also in attendance at this meeting, agreed to begin advertising for the position of Executive Director, a position officially created by the adoption of the Committee recommendations. The Commission also decided that the Budget and Personnel Committee would screen applicants for the position. Next on the agenda at that second meeting was a report by the Chairman of the Rules and Procedures Committee, Campbell Richardson, in which he discussed the proposed rules and procedures which the Committee was in the process of drafting. After the general discussion, the Cormittee decided it would have a complete draft prepared for the July 30 meeting and the mandated public hearing would be held August 8, 1969. Logan agreed to take care of the public notification for the hearing. The Rules and Procedures Committee ran behind the other two simply because its task required much more detailed work than the others. At the meeting on July 30, the Committee and the Commission discussed the draft and compared it with the rules compiled by the itarion-Polk Commission and the King County, Washington Boundary Board. On the basis of these discussions, a final draft was subsequently prepared for the public hearing scheduled for August 8, which was modified and adopted at that time to become effective on September 7, 1969.

The other major item of unfinished business, the hiring of an Executive Director, moved even more slowly than the adoption of rules and procedures. Chairman Cease, in Marilyn Gunsul's absence, reported 
to the Commission at the July 30 meeting that he had received only about six applications and several phone calls expressing interest in the Executive Director position and that the Committee would meet again in about three weeks. In the interim, Chairman Cease arranged with the PMSC, through Rich, to provide staff services until the Commission had hired its own staff. While the Budget and Personnel Committee had been given the responsibility of screening the applicants, Chairman Cease took a very active role in the selection of the staff, and his experience in such affairs contributed to avoiding what may have been a crucial error.

By September 4, the Commission had received a number of additional applications and the Commission at its meeting on September 4, interviewed several candidates for the position of Executive Director, including the present Executive Director, Don Carlson, who was at that time an assistant to Rich of the PMSC. One of the other applicants made a very good impression with the Budget and Fersonnel Committee and had what appeared to be excellent credentials and qualifications-on paper. 'There was strong support on the Commission to hire this individual, who also had the advantage of being the son of a well-known local government official who himself was a good friend of one of the members of the Commission, an individual who gave the applicant's candidacy outspoken support. Cease, however, was quite wary of hiring someone solely on the basis of written applications and recommendations, having done so while working in the governor's office in Alaska and "been burned." After those experiences, he decided that he would never again hire for an important position solely on the basis of written applications and 
recommendations, but would be sure to make verbal contact with specified references, persons at former employers who would have personal knowledge of the applicant, mutual acquaintances, and other people who would be able and willing to provide informal candid comment on the applicant in question. Cease asked for time to "check the applicant out." In the process, Cease found a record which originally had been interpreted as one which demonstrated a diverse background and considerable competitive demand for the applicant's services among institutional employers, but which also suggested that the person made a very good first impression but seldom delivered an adequate performance once hired. 16 As a result, the applicant was not hired. The characteristics which Cease was looking for in an Executive Director consisted of both an ability to perform the research and study necessary for proposal assessment as required by the Boundary Commission Law, and an ability to carry out what might be termed the public relations component of the Executive Director position. 17 Chairman Cease felt the initial relationships created between the Commission and other units and agencies of government would be crucial to its future and he wanted a "mature personality" to carry out that mission. 18 Cease and the Commission felt they had such a person in Phil Hollick and subsequent discussions with commissioners who worked with Phil Hollick confirmed this judgment. Cease was also looking for one additional qualification which he felt would contribute to the person's ability to carry out the public relations mission. He wanted to "bring someone in from the outside." 19 Someone who did not have any enemies in the local area whose enmity toward the Executive Director might spill over onto 
the Commission itself.

Thus, by September 11, 1969, the Portland Boundary Commission was fully operational, having completed in a little over two months all of the organizational tasks necessary to put it into operation. It had organized itself internally by establishing a leadership and staff structure. It had prepared, held a public hearing on, and adopted rules and procedures. It had filled its most important staff position, Executive Director. As will be made more emphatic elsewhere, three decisions reached during this period turned out to be very important to the future of the Commission: the decision to staff independently,* the election of $\mathrm{Dr}$. Ronald Cease as the first Chairman, and the hiring of Phil Hollick as the first Executive Director.

* While this decision did not amount to a specific rejection of CRAG, the CRAG Executive Board subsequently refused, on several occasions, to nominate persons to serve on the Advisory Board created by ORS 199.450 . 
FOOTNOTES

1. Oregon Legislature, Joint Interim Committee on Local Government, "Minutes of Interim Committee hearing on ICC 192," September 13, 1968, Salem, Oregon State Archives.

2. ORS 199.435(2).

3. A. McKay Rich, Private interview, Portland, October 2l, 1977.

4. ORS 199.452(1).

5. ORS 199.452(2).

6. ORS 199.452(3).

7. ORS $199.415(12)$

8. Cease, Report, p. 7 .

9. Ibid., p. 7 .

10. A. McKay Rich, Private interview, Fortand, July 25, 1978.

11. Ronald Cease, Private interview, Portland, July 25, 1978.

12. ORS $199.455(2)$.

13. Portland Boundary Commission, "Minutes," July 16, 1969, Portland, Portland Boundary Commission files.

14. Ibid.

15. Marilyn Gunsul, Private interview via telephone, Portland, February 20, 1978.

16. Ronald Cease, Private interview, Portland, July 25, 1978.

17. Ibid.

18. Ibid.

19. Ibid. 
CHAPTER IV

THE COMISSION AND THE LEGISLATUEE

The legislative process is never finished but continues from year to year, or in Oregon's case, from biennium to biennium. Battles won or lost in one session can be fought again in the next. No one ought to rest too comfortabiy on a legislative victory or be too disheartened by a defeat because there is always "next time." The legislative process in reference to the boundary commissions was renewed almost immediately after the commissions came into existence. The first indication that additional legislation would be necessary came when the Portland Commission attempted to implement the law and found it to be rife with inconsistency, omission, and unintended consequences. ${ }^{1}$ An immediate result of this situation was a great volume of correspondence between the Commission and the State Attorney General's office requesting clarification of the law. The result of these difficulties was the development of H.B. 1056, the major piece of boundary commission legislation in the 1971 session.

Most of the content of H.B. 1056 originated within the commissions themselves. As early as July, 1970, representatives of each commission and their respective staffs met in Salem to discuss changes in the law, legislative strategy, and mutual problems and policies. After further refinement by a cooperative effort of the staffs, these proposals were presented to the Interim Committee on Urban Affairs and Transportation. 
The Interim Committee engaged the services of Jane Gearhart, Legislative Counsel, to put the proposals in bill form and the result-HC 440was adopted as a Committee bill and introduced into the 1971 Iegislature at the request of the Interim Committee. The bill as introduced, H.B. 1056, was basically a "housekeeping bill" and proposed no major changes in the structure, jurisdiction or powers of the commissions. The term "housekeeping bill" denotes a bill which makes no significant change in the structure or function of the agency and once applied to a bill, most legislators not directly involved would view it as noncontroversial and give it little attention. The bill as passed, however, contained language which in concert with other legislation significantly increased the authority of the commissions over special districts. These changes increasing authority over special districts were not generated from within the commissions but came as the result of outside initiative.

Representative John W. Anunsen, the most important backer of the original boundary commission legislation, had organized in 1970 a series of four conferences on local government held around the state. Representative Anunsen had become convinced as a result of his work with local government legislation that the existing conferences on local government, held by such organizations as the League of Oregon Cities, were too narrowly focused on their own problems and that when these bodies came to the legislature, they came to get what they could individually. Nowhere, he felt, was there a forum for the discussion of local govermment on an "all inclusive" basis." In response to this, inunsen initiated the series of conferences which came to be known as 
Decisions and Directions. Invited to these conferences were elected city and county officials, legislators, businessmen, members of the executive department of the state, representatives of labor, the League of Women Voters, and many others. By the third conference, the conferees had decided upon a strategy of analyzing the functions performed by local government and assigning the entire function or phase of a function or combination, by units of government. Forty-six pages of questions breaking down the functions into nine basic areas such as water, sanitary, and safety were presented to the conferees. The results of this analysis were very much like those of most studies of local government structure and function: small units ought to be discouraged; large units ought to be encouraged. Foremost among those small units of local government to be discouraged were special districts and Representative Anunsen developed a three-step strategy to eliminate as many of them as possible. He felt special districts were at the same time the most numerous problem and the most vulnerable politically. ${ }^{3}$

One of the three steps was to attach to the budgets of the boundary commissions the following footnote.

The subcormittee approved the budget for the Commission as recommended by the Governor. In approving the Commission budget, the subcomittee expressed strong legislative intent and direction that insofar as possible the commission should accelerate and concentrate its efforts toward special service districts within its jurisdiction. The commission is directed to begin to investigate such special districts as soon as possible and to initiate proceedings to consolidate or eliminate such districts and transfer their functions to other units of government, i.e., cities, county service districts, or multiple service metropolitan service districts. The boundary boards shall transmit to each member of the 
legislature and other interested parties a report of their action in this area from time to time and to the 1973 legislature.*

This could leave little doubt in the mind of any boundary commissioner as to legislative intent or priority.

The second step was to give the boundary commissions additional authority to carry out this mission. On April 20, 1971 with H.B. 1056 in the House Committee on Urban Affairs, the following amendment was added to the bill.

(c) The final order, in a proceeding to merge or to consolidate districts or to dissolve a district and transfer its functions, assets and liabilities to a county service district, shall conclude the proceeding for all purposes; and the merger, consolidation or dissolution and transfer shall take effect 45 days after the date the commission adopts the final order in the proceeding.

The effect of this amendment was to give the commissions the power to consolidate special districts without a vote. Prior to this, such a procedure would have reverted to the "principal act" after commission approval and the principal act required elections, a procedure which made it very difficult to eliminate special districts.**

* Budget footnotes are attached by the subcommittees or the full Committee on Ways and Means. They are not a part of any legislation. They are not a part of the appropriation bill. They do, however, carry considerable political force as they reflect the attitude of the powerful Ways and Means Committee and any agency which ignores the footnotes does so at its peril. The footnotes are attached to the Budget Report prepared by the Budget Division of the Executive Department which is on the desk of each legislator as the appropriation bills are voted.

** "Principal act" means, with reference to a city, ons chapters 221 and 222 and, with reference to a district, the statutes, other than ORS 199.410 to 199.514, which describe the powers of an affected district including but not limited to the statutes under which a district is proposed or is operating. ORS 199.415(16). 
In addition to this added power, H.B. 1056, even in its original form, added metropolitan service districts to boundary commission jurisdiction. A number of other types of districts were originally in the bill but were removed from the bill in the House Committee on Urban Affairs. While this legislation removed the major obstacles to the elimination of special districts, a third step was necessary if the footnote policy was to be carried out.

The majority of special districts were located in unincorporated county surrounding existing cities. While preferring annexation to cities or inclusion within multiple service districts, where this was not possible, Representative Anunsen desired that the functions of the special districts be assumed by county service districts. This would centralize administration in the county commission and provide a more regional approach to the provision of services in unincorporated areas. To make this possible, H.B. 1603, 1971, was passed into law. H.B. 1603 provided that within the territorial jurisdiction of boundary commissions, county service districts could undertake a number of functions they could not undertake outside of boundary commission areas. These included: fire protection and prevention; domestic, municipal and industrial water supply; hospital and ambulance services; library services; vector control; cemetery maintenance; solid waste disposal; roads; and weather modification. The passage of H.B. 1056 and H.B. 1603, in concert with the existing power to initiate boundary changes, completed the set of formal legal powers necessary to pursue the policy outlined in the budget footnote.

The Portland Boundary Commission had been very actively pursuing 
the footnote policy even before there was a footnote. In its first year of operation, the Commission initiated five proposals which eliminated 63 highway lighting districts. Highteen more were eliminated by proposals initiated outside the Commission. It had been possible to do this under the old law using the annexation process. By annexing the districts in their entirety to a county service district, they were automatically dissolved and the effect of merger and transfer was achieved through the process of annexation. Although these boundary changes were subject to remonstrance, there were none because they were not, by and large, controversial. They were not because there were no entrenched staffs and only limited taxes and minimal assets. These districts generated little of the parochial attachment to independence that often accompanies local governments. When, however, the Commission attempted under the old law to consolidate special districts which did not possess these noncontroversial characteristics, they were much less successful. On February 24, 1971, the Commission initiated a proposal to merge two Multnomah County Rural Fire Protection Districts which it approved March 17, 1971. After Commission approval, the procedure reverted to the principal act and the proposal was defeated in the ensuing election. 4 The Commission reintroduced the same proposal on September 8, 1971, approved it on October 6, 1971, one day after the new law took effect, and under the new law, the merger took effect 45 days later. ${ }^{5}$ During the next year, the Commission initiated and approved a series of major special district consolidations that would not have been possible without the new law. ${ }^{6}$ As early as July 9, 1971 , only ten days after the Governor signed H.B. 1056, the staff of the 
Commission stated that,

We have no doubt that the Commission prefers to take the 'bold' approach and proceed toward the development of a program that would involve the initiation of special district consolidations on a large scale. 7

During the period July 1971 to December 1972, the Commission eliminated four water districts and three fire districts. ${ }^{8}$ Prior to this period, there had been no successful consolidations of fire or water districts initiated by the Commission and only one was successful from an outside initiation. Multnomah County RFPDs \#10 and \#2 (Parkrose) were consolidated as the result of an election initiated by the PMSC. The law creating the PMSC granted it authority to place measures affecting local government organization directly on the ballot in regular elections. The Boundary Commission gave its informal approval to the proposal but considered itself to lack legal jurisdiction in this case.

Changes in the Boundary Commission Law in the 1973 session differed from those made in the 1971 session both quantitatively and qualitatively. The 1973 session passed a far greater number of bills which made significant changes in the law than did the 1971 session. The 1973 session passed seven bills not including appropriations, the 1971 session three. Qualitatively, the changes made in the 1973 session were broader in scope than 1971. The major change in the 1971 session was intended to enhance the Commission's ability to simplify and reorganize the system of local government. Of the three major changes made in the 1973 session, one was aimed at this same system reorganization role. The other two, however, were aimed at increasing the Commission's ability to perform its second role, that of guiding the 
orderly expansion of urbanization.

Unlike the 1971 session, the legislation introduced into the 1973 session proposing significant changes developed within the commissions. The major change aiming at system reform, H.B. 3105, involved changing the legislation for consent annexations to cities from a triple twothirds requirement to a triple majority. Under the law, a city governing body in possession of a petition for annexation containing two-thirds of the property owners of two-thirds of the land area to be annexed and representing two-thirds of the tax valuation of the area, could annex the area by ordinance. Consent annexations are those in which the affected parties express legal consent to the proposal as part of the initiation process. Therefore, no further expression of consent, such as an election, is required. The commissions supported this request on the basis that it would increase the effectiveness of the commissions in eliminating city fringe area problems by increasing the commissions' ability to eliminate confusing and irrational boundaries. In addition, the commissions felt it would substantially reduce the large numbers of gerrymandered consent petitions coming before the commissions in the first instance. Because the consent annexation law did not require coherent or rational or nongerrymandered boundaries, petitioners would often draw the boundaries of the annexation to meet the triple-two-thirds criteria at the expense of the rational boundaries the commissions were charged with achieving. In these consent annexation proposals, the cities themselves were the usual initiators of the petitions which generally contained the minimum number of signatures. Thus, they could not be modified by the comnissions by adding area to 
achieve orderly boundaries. Prior to Madsen, the Portland Commission did modify triple two-thirds proposals to the point where the signatures no longer constituted the two-thirds majorities required. In Madsen vs. City of St. Helens, 1972, the Columbia County Circuit Court found the commissions lacked such authority. The commissions felt that the less stringent requirements of triple majority would increase both the quantity and quality of the proposals they were receiving.

The other major pieces of legislation in the 1973 session were aimed at enhancing the ability of the commissions to control the process of urbanization, primarily that aspect involving the conversion of raw land to urban use. Significantly, from their inception, the boundary commissions had been involved with questions which affected the conversion of land to urban use. One of the first policy-oriented acts of the Portland Commission was to request the cities within its jurisdiction to prepare descriptions of their "spheres of influence," in cooperation with the counties, to guide commission decision-making. The commission served notice that it would be looking beyond the governmental aspects of proposals to their land use impact; "attempts to annex significant tracts of undeveloped land to a city to avoid county controls shall be firmly discouraged." 9 This policy was adopted in response to a number of cases where property owners were annexing to cities to avoid existing county land use planning and zoning and to obtain more favorable conditions from the city. They were, in effect, "shopping" the jurisdictions for the most favorable zoning and land use. This was the earliest evidence of the Commission's intention to implement land use plans made by genergl units of government by 
controlling access to services and utilities through their ability to control governmental stmucture. ${ }^{10}$ As the Commission became more heavily involved with proposals in which stmuctural decisions were based less on duplication, fragmentation, and orderly boundaries, and more on urban sprawl and land use conversion, the Commission became aware that its authority over structure had certain omissions which limited its ability to control land use through the control of urban services, especially water.

Prior to the 1973 session, both the Portland and Lane County Commissions had experienced situations in which these omissions were utilized by units of government to subvert the authority of the commissions. Once the commissions were made aware of these problems by specific cases, they began to realize on a theoretical basis that there were a number of points of weakness. Their ability to prevent the conversion of raw land to urban use by preventing water service to the area had been undermined by incomplete jurisdiction and authority over entities, public and private, capable of providing water service. Normally, thei: power to deny formation of special districts and to deny annexation to cities or special districts had been adequate tools in preventing the extension of urban services, especially water, to areas considered not suitable for urbanization. The Lane County Commission had considered an annexation proposal which was based on the need for city water to develop a parcel of property. After disapproving the annexation because it constituted unwise urbanization, the annexing city, in turn, extended water to the area extraterritorially. The City of Wilsonville informed the Portland Boundary Commission during the 
hearings on the Charbonneau annexation that it would extend water service to the development extraterritorially if the Commission disapproved the annexation. 11 subsequent examination of the statutes revealed a number of ways that water services could be established without commission review and the commissions developed legislative proposals to deal with them.

H.B. 3106, 1973, contained three features extending the commissions' control over water supply. It provided the commissions with the power to review the addition of functions to special districts and county service districts which were empowered under their principal acts to provide more than one service. The commissions argued that the addition of functions to existing districts had the same effect as the formation of a new district, a procedure over which the commissions did have jurisdiction, and thus the addition of functions ought to be within their purview. Secondly, H.B. 3106 gave the cormissions the authority to review the extraterritorial provision of water service and the extraterritorial extension of sewer mains by cities and districts. Again, the commissions argued that extraterritorial extensions of water and sewer mains had the same effect as annexation to, or formation of, a city or district, procedures which were under the commissions' jurisdiction. To complete the commissions' control over water supply, H.B. 3106 also granted authority to review the establishment and extension of private community water and sewer systems.*

* "Community water supply system" means a source of water and distribution system, whether publicly or privately owned, which serves more than three residences or other users where water is provided for public consumption including, but not limited to, a school, farm labor camp, an industrial establishment, a recreational facility, a restaurant, a motel, a mobile home park, or a group care home. ORS 199.464(7)(c). 
The commissions also attempted in 1973 and again in 1975 to include within their jurisdiction a number of types of special districts which were legally empowered to provide water service. On both occasions they were unsuccessful, primarily because these particular types of districts were considered by the legislature to be essentially mural in character. Oregon law provides many types of special districts with authority to perform more than one function and the following districts could provide domestic water supply in addition to their primary function: irrigation, drainage, water improvement, water control, and water use and control. The request for irrigation, drainage, diking, and water use and control districts was dropped from H.B. 2052, 1975, when it went to the Senate Local Government and Elections Committee because it appeared the law would have to be amended to allow for property owner remonstrance rather than existing qualified voter remonstrance.

The most meaningful aspect of the 1973 revisions was the extent to which the "orderly expansion of urbanization" was beginning to overtake the "simplification and reorganization of government" as the major focus of the commissions. The commissions made no attempt to include the water supply oriented revisions within the structural reorganization rubric, but defended the proposals to the legislature squarely on the basis that they were a necessary tool if the commissions were to help implement county and regional land use plans. 12

The addition of control over sewer and water was the last significant change in the jurisdiction or authority of the commissions. The 1975 session saw the passage of legislation of a "housekeeping" nature 
which had been requested by the commissions. 13 when asked by the Interim Committee on Local Government and Transportation on June 26, 1974, if the commissions foresaw a need to expand their role in terms of additional legislation, the Chairman of the Portland Commission, Anthony Federici, replied they did not.

In the first three legislative sessions following their creation, the boundary commissions faced only two attempts to pass legislation reducing their jurisdiction and powers. 14 Both occasions involved an attempt by interests in Clackamas County to remove the language added in 1971 to allow consolidation of districts without a vote. On both occasions, the bills died in committee in the initiating chamber. While the commissions faced little opposition in the form of debilitating statutes over this period, the voting records on their major substantive bills and on their appropriations indicate an erosion of support. The major bill in the 1971 session, H.B. 1056, passed the Senate 26 to 1 and repassed the House 57 to 3. The 1971 appropriation, H.B. 2089, passed the House 52 to 7 and the Senate 21 to 9. The major bill in the 1973 session, H.B. 3106, passed the Senate 20 to 5 and repassed the House 34 to 21 and the 1973 appropriation, H.B. 5009, passed the House 35 to 23 and the Senate 17 to 12. By the 1975 session, the margins of victory had grown smaller. H.B. 2053, one of the two bills of any significance in the 1975 session, passed the Senate 16 to 12 and repassed the House 41 to 15. The margin in the Senate is significant when one considers the fact that the bill was basically a housekeeping bill correcting cumbersome procedures created under the 1973 legislation granting authority over sewer and water. The other bill of any significance, 
H.B. 2052, 1975, which attempted to add a number of types of special districts to the jurisdiction of the commissions, after passing the House 40 to 12 , failed to pass the Senate on a 15 to 15 vote following a strong lobbying effort mounted after its first defeat on the Senate floor 12 to 16 the previous day. The commissions first attempted to add these districts in H.B. 3095, 1973, but that section was amended out of the bill in the House Local Government and Urban Affairs Committee. Only one other boundary commission related bill of any significance had passed one chamber but failed in the next. H.B. 3099, 1973, passed the House 34 to 23 but was taken from the calendar, after having been sent from the Senate Local Government and Urban Affairs with a "do pass" recommendation and re-referred to the Senate State and Federal Affairs Committee where it was tabled. H.B. 3099 attempted to grant to the commissions authority to modify consent annexations and put them into effect regardless of the eventual majorities, a practice struck down by Madsen vs. City of St. Helens, 1972. But the bill was made moot by the passage of $\mathrm{H} . \mathrm{B} .3105$, 1973, which reduced the required majority to a simple majority. Thus, the defeat of H.B. 2052 in 1975 can be considered the first defeat of a boundary commission bill which had been requested by the commissions and intended anything more than a housekeeping change. Only two other bills introduced at the request of the Boundary Commission failed to pass. H.B. 3096, 1973, which would have provided for automatic withdrawal of territory from sewer and water districts upon annexation of the territory to a city, and H.B. 3103, 1973, which would have eliminated the 45-day waiting period on consent peti.tions signed by all real-property owners. The vote on the 
appropriations bill, H.B. 5052, in 1975, was about the same as 1973 in the House, passing the House 36 to 24, but passage in the Senate 24 to 2, was stronger than either 1971 or 1973.

Perhaps the more important aspect of the appropriations process and the degree to which it is indicative of legislative support is the amount passed. The Portland Commission budget approved in 1971 for the 1971 to 1973 biennium was \$95,010; for the 1973 to 1975 biennium $\$ 112,478$; for the 1975 to 1977 biennium $\$ 126,965$. This represents a funding increase of only about 33 percent over this period which, allowing for inflation, means that the Portland Commission has not had a "real" budget increase. The budgets of the other two commissions reflect the same situation: Salem, 1971-1973, $\$ 55,768$; 1973-1975, $\$ 71,059 ; 1975-1977, \$ 79,231$. Eugene: 1971-1973, $\$ 53,933 ; 1973-1975$, $\$ 59,660 ; 1975-1977, \$ 77,232$. Indeed, the state supported staff of the Portland Commission has not increased over this period, despite the increase in the work load. The agency budget requests have been as modest as the increase. The 1971 to 1973 and 1973 to 1975 requests each contained a $\$ 30,000$ item for funding studies which in both cases was eliminated and the 1975 to 1977 request included an additional $\$ 32,064$ to fund an additional half-time secretary and full-time administrative analyst, which was removed. The Portland Commission has always requested more than it eventually received but only modestly so because the Executive Director, Don Carlson, has never felt there to be enough legislative support to make larger requests. ${ }^{15}$ 
FOOTNOTES

1. William Linklater, Letter from William Linklater, Assistant Attorney General, to Ronald Cease, Chairman, Portland Boundary Commission, responding to ten questions requesting clarification and interpretation of the law, December 30, 1969, Portland, Portland Boundary Commission files.

2. John W. Anunsen, Private interview via telephone, Portland and Salem, March 1, 1978.

3. Ibid.

4. Portland Boundary Commission, Commission Resolution No. 6, Proposal No. 260, Portland, Portland Boundary Commission files.

5. Portland Boundary Commission, Commission Resolution No. 9, Proposal No. 284, Portland, Portland Boundary Commission files.

6. Portland Boundary Commission, Commission Resolution Nos. 8, 9, 10, 13, 14 and 15, Portland, Portland Boundary Commission files.

7. Portland Boundary Commission, "Memorandum to Boundary Commission from Staff," July 9, 1971, Portland, Portland Boundary Commission files.

8. PortI and Boundary Commission, "Biennial Statistical Summary," Narch, 1973, Portland, Portland Boundary Commission files.

9. Portland Boundary Commission, "Poi.icy on Land Use and Coordinated Planning," May 20, 1970, Porìland, Portland Boundary Commission files.

10. Portland Boundary Commission, "General Principles and Criteria for Considering a Wide Range of Boundary Change Proposals," March 20, 1970, Portland, Portland Boundary Commission files.

11. Don Carlson, Private interview, Portland, March 13, 1978.

12. Don Carlson, Letter from Don Carlson to Keith Burns, Chairman of the Senate Local Government Affairs Committee, "Legislation Affecting Boundary Commissions," May 14, 1973, Portland, Portland Boundary Commission files.

13. H.B. 2225, H.B. 2775, H.B. 2954, Oregon Legislative Assembly, 1975 Regular Session. 
14. S.B. 501, Oregon Legislative Assembly, 1973 Regular Session. S.B. 633, Oregon Legislative Assembly, 1975 Regular Session.

15. Don Carlson, Private interview, Portland, March 20, 1978. 


\section{CHAPTER V}

\section{THE COMMISSION IN AN INTERGOVERNMENTAL CONTEXT}

The Yortland Eoundary Commission is involved to some degree with a large number of units of government and agencies of government in the performance of its duties. The frequency of contact between the Commission and other agencies or units of government is determined largely by proposals brought before the Commission. Because annexations to cities are the most numerous type of proposal, the contacts between the Commission and the cities within its jurisdiction are concomitantly the most numerous. Under the law as amended, measured July 1, 1973 to June 30, 1977, annexations to cities constituted 284 of 625 proposals or

approximately 45 per cent. ${ }^{1}$ Frequency of contact, however, does little to inform about the locus of the Boundary Commission within the web of government. Of more importance is the way in which the Boundary Commission is affected by, and, in turn, has an effect upon, other units and agencies of government in a functional sense.

The intergovernmental relationships of the Commissioñ are of two basic types. One is those relationships in which other units or agencies of government provide the Commission with resources necessary to its function, known as input relationships. The other is those relationships wherein the Commission acts upon and significantly affects the functioning of other units of government, or output relationships. The input side of the equation can be usefully divided into four basic 
categories: legislative, technical, administrative, and policy.

Legislative inputs to the Commission have been provided by the

local government committees of the House and Senate, the interim cormittees on local government, the joint committees on ways and means, and individual legislators who usually are also members of the interim and regular local government committees. These legislators would include Frank Roberts, John Anunsen, Ed Fadely, Glen Otto, Roger Martin, Ralph and Iick Groener, and others. ${ }^{2}$ The committees not only provided the basic law for the Boundary Commission but have also changed the law over time to facilitate the Commission's operations. As mentioned elsewhere, the process of revising the law began almost immediately after the Commission went into operation and involved the three boundary commissions, the interim committees, and the regular committees. Until a Legislative Task Force to examine the commissions was appointed during the 1977 Session, there had been no attempt by the legislature to exercise oversight over the commissions, and contact with the legislature had been sporadic. ${ }^{3}$ While most of the changes in the law have come at the request of the commissions, only the legislature could incorporate them into the law, and the commissions are dependent upon the legislature to supply needed legal authority, such as the ability to consolidate special districts without a vote. There is also another route by which the legislature affects the Commission's functions. Through its control over appropriations the legislature and most particularly the ways and means commititee has a continuing affect upon the Commission's operation. The failure to increase the budget of the Commission, and thereby the size of the Commission's staff has limited 
the ability of the Commission to study and develop substantive proposals on its own initiation as effectively as if the Law prohibited or limited the option to initiate. The relationship between the Commission and the local delegation is not very close and actual contact is infrequent. 4 Most contact with members of the local delegation is centered around their positions on the relevant legislative committees rather than on the fact that their districts fall within the Commission's territorial jurisdiction. Occasionally a member of the local delegation will act as an intermediary between private individuals or units of government in his district and the Commission, but such contacts are infrequent. 5 There is no evidence to support the idea that the Commission or the staff accord the local delegation extraordinary influence with respect to proposals originating within their districts; nor is there any evidence that the legislators are desirous of such an arrangement. Nevertheless, the Commission's staff and the more politically sensitive members of the Commission are aware of the omnipresence of the local delegation and attempt to act in such a way as to avoid their wrath. with respect to the legislature as a whole, the Commission, in spite of its relatively autonomous operation, realizes that they who giveth also can taketh away.

The Commission has more or less frequent contact with a large number of state and federal agencies from which it receives input of a primarily technical nature. Due to the limited staff of the Commission, it is heavily dependent upon outside sources of expertise when dealing with proposals which raise questions of a technical nature. The Commission also comes into contact with other state agencies in the 
process of verifying plans submitted as parts of proposals. For data analysis, the staff occasionally utilizes the services of the heal Estate Commission and the Corporations Commission in determining land ownership and private water system ownership. The Commission utilizes the State Department of Environmental Quality (DEQ) and the Federal Environmental Protection Agency to verify the capital expenditure projections and the status of federal and state grants which are often components of plans for sewer systems. The DEQ also supplies the Commission with information on treatment plants and the general adequacy of existing and proposed sewer and water facilities. The Commission utilizes the expertise of the State Water Resources Board in reviewing the design and performance specifications of water wells when they are part of a proposal. The Columbia Region Association of Governments also provides technical assistance upon request.

As is the case with most boards and commissions in Oregon, the Boundary Commission operates relatively autonomously and is not a part of a regular department. ${ }^{6}$ It does, however, operate under the general umbrella of state law pertaining to the budget, accounting, and personnel administration of the agency. The Commission negotiates its budget with the Executive Department, receives appointments to the Commission from the Governor's Office, and is audited by the Secretary of State. Aside from these functional contacts, the Commission receives little in the way of administrative input. The Commission's relationship with the successor to the Local Government Relations Division, the Intergovernmental Relations Division, is limited to the filling out of Division questionnaires and responding to letters received by the 
governor and channeled to the Commission through the Division. Aside from the policy effects inherent in the processes of appointing commissioners and negotiating the budget proposals, the Executive branch has not attempted to influence the actions of the Commission generally or in particular cases.

Since its inception, the Commission has had a very active relationship with the Attorney General's office which serves as the Commission's counsel. William Linklater has had responsibility for the boundary commissions within the Attorney General's office since their inception and his primary function in serving the Commission has been to provide legal opinion and interpretation of the statutes. Much of this contact is informally conducted by telephone. From time to time the Commission requests an informal written opinion for the purpose of substantiating its action, but under state law such informal opinions are not binding on the Commission. The Portland Commission has never requested a formal, and therefore binding, opinion from the Attorney General. These legal services are not without cost. The cost of legal services is charged against the Commission's account when the services pertain only to the Portland Commission. Those opinions and services which are of a generic nature are often charged on a prorated basis against the accounts of all three commissions by agreement of the commissions' staffs. The fact that legal services tax the limited budget of the Commission has apparently not made the threat of legal challenge an effective weapon against the Portland Commission. The Commission staff claims never to have changed its behavior as a result of the threat of suit. The staff considers legal expenses as an 
uncontrollable and open-ended budget item, because it feels the legislature will approve funds necessary to defend actions taken by the Commission in the legitimate exercise of its duties. 7 The commissions have also utilized the expertise of Linklater in the drafting of bills to revise the basic law. To some degree, the Commission's relationship with the Attorney General's office encompasses all four input categories: legislative input through statutory revision and the administrative provision of technical services which have a policy effect.

The final category of input-policy--is supplied to the Commission by the Land Conservation and Development Commission (ICDC), the Columbia Region Association of Governments (CRAG), Clackamas, Washington, Columbia, and Multnomah counties and the cities within these counties. From its inception, the Commission has followed a policy of acting in conformance with land use planning by examining every proposal with respect to its compatibility with existing or proposed land use plans developed by units and agencies of government which have formal, legal powers and responsibility to develop comprehensive land use plans. 8 In the earliest phases of its operation, the Commission often found itself in a situation where it was making boundary decisions in a vacuum because there were no city or county land use plans for the area in question, or they existed but were in conflict. The Commission realized that "guiding the orderly extension of urbanization" required land use plans and that the Commission had neither the power nor the resources to provide such planning for its own use. Ihus, one of the first acts of the Commission was to request the cities within its jurisdiction to propose a "sphere of influence" plan and to coordinate their plans with 
the appropriate county or counties. Some cities had no land use plans for the urban fringe and in some cases such plans were in conflict with county plans for the area. 9 In September, 1973, the Commission began to view proposals against not only city and county land use plans but also the CRAG Interim Development Policy. ${ }^{10} \mathrm{All}$ proposals before the Commission since that time have been routinely sent to CRAG for review and comment in light of the CRAG Framework Plan Element. The final source of policy input was added in 1977, when the Commission began to apply the LCDC Goals and Guidelines to all proposals. In Peterson vs. Mayor and Council of the City of Klamath Falls the Oregon Supreme Court held that city annexations must be consistent with LCDC goals and the 1977 Legislature extended Peterson to annexations to several types of special districts. 11 Even before this legal and legislative action, the Commission had been applying the LCDC Goals and Guidelines by virtue of ORS 197.180 which the Commission interpreted as requiring all state agencies to follow and act in compliance with LCDC goals. The Portland Commission began applying LCDC Goals and Guidelines in their entirety with proposal No. 1092 on June 29, 1977, a month before Peterson was filed with the Supreme Court and six months before the decision; S.B. 100, 1973, Section 21, State agencies shall carry out their planning duties, powers and responsibilities and take actions that are authorized by law with respect to programs affecting land use in accordance with state wide planning goals and guidelines approved pursuant to this act. ${ }^{12}$ while in most situations in which the actions of an agency are limited by the actions of another agency or unit of government, the resulting intergovernmental relations are characterized by tension or 
hostility-this is not the case with the Portland Boundary Commission. All of these policy inputs to the Commission have been to some degree sought out by the Commission and voluntarily incorporated into the Commission's procedures.

The second basic type of intergovernmental relationship-outputis that in which the Commission acts upon and significantly affects the functioning of other units of government. This output side of the Commission's intergovernmental relations is basically shaped by the Boundary Commission Law when it defines the legal powers and jurisdiction of the Commission. The law determines which units of government will have a cliert relationship with the Commission. Not all clients of the Commission are governments. One class of clients involves neither an existing nor proposed unit of government. This class consists of private persons or corporations engaged in, or proposing to engage in, private water or sewer systems. They come as clients to the Commission to: create a private sewer or water system, extend extraterritorially such sewer or water systems, and, in the case of water systems, to receive an allocation of service area. Another class of client consists of groups acting on their own initiative to create a unit of government. Individuals can propose by initiative petition the formation of a city, county service district, or special district. Such a proposal cannot be considered as directly intergovernmental because the unit of government in question does not yet exist. Together, these two classes of clientele, not directly intergovernmental, constitute only about eight per cent of the proposals considered by the Commission. ${ }^{13}$ 
The Boundary Commission Law grants certain powers to the commissions to review specific types of boundary changes to existing units of government. In so doing, it creates a client relationship between the Boundary Commission and cities, counties, and special districts. This client relationship can be further reduced to its three major components: primary, secondary and intermediary-each of which builds upon the former but is ultimately based upon the law itself. Jurisdiction over the following boundary changes mandatorily creates primary intergovernmental relationships. Primary intergovernmental relationships are those in which the unit of government is a party to the proposal and the relationship is bilateral. In a proposal to annex territory to a city, the city would be engaged in a mandated primary relationship with the Commission. The universe of such relationships is explicitly defined in the law:

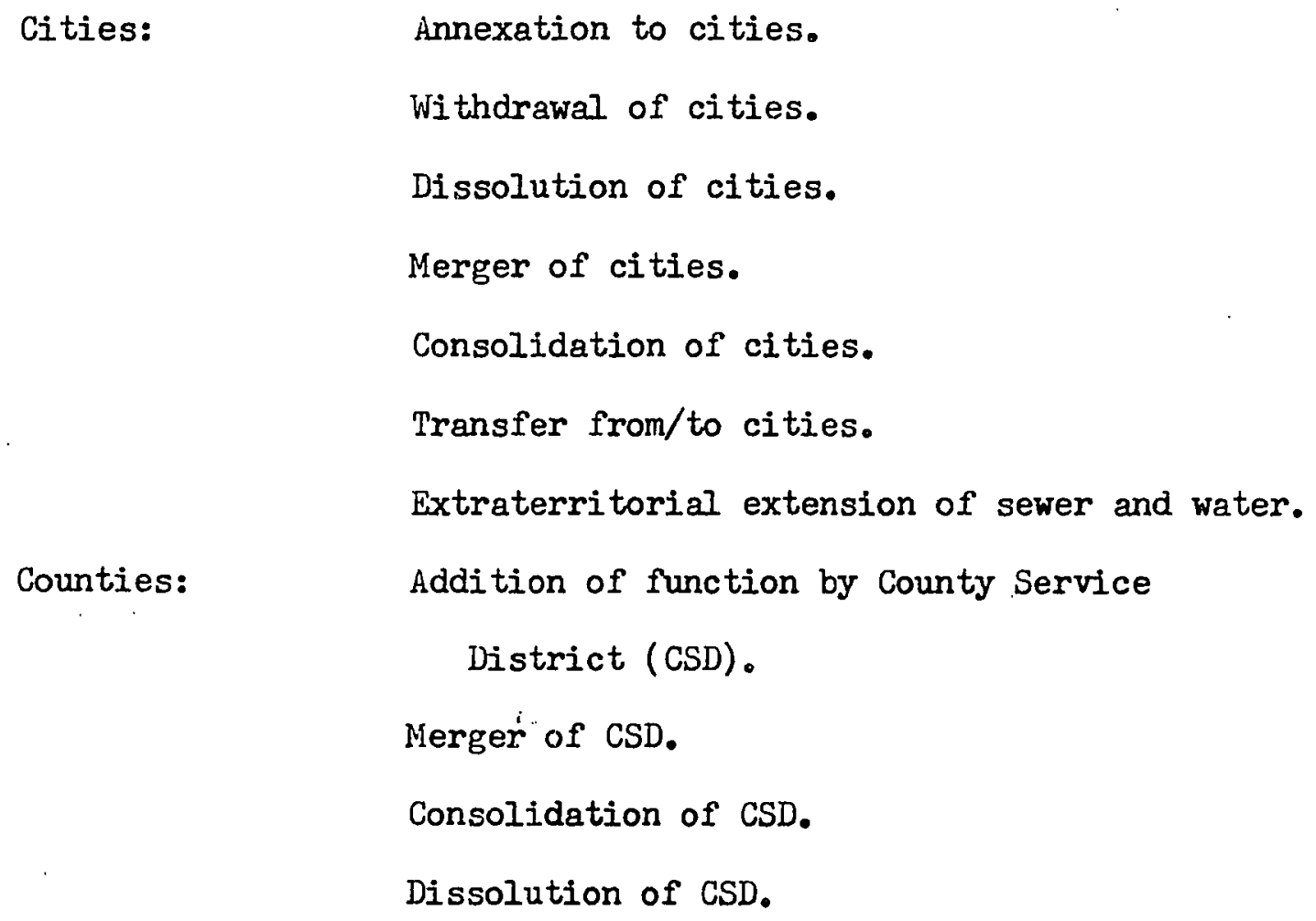


Withdrawal from CSD.

Annexation to CSD.

Transfer from/to CSD.

Extraterritorial extension of sewer and water by CSD.

Special Districts: Annexation to special districts.

Dissolution of special districts.

Merger of special districts.

Consolidation of special districts.

Transfer from/to special districts.

Withdrawal from special districts.

Extraterritorial extension of sewer and water. Addition of function by special districts.

Each boundary change under these areas automatically creates a mandated primary relationship between the Commission and the respective unit of government.

Secondary intergovernmental relationships arise from the spill over effects of boundary changes and create bilateral relationships between the Commission and one or more units of government which are affected by a boundary change but are not directly a party to it. Secondary relationships are not individually defined by type of boundary change, as are the primary, but are defined as a class on the basis of the effect of boundary changes in the policy statement of the basic law: "The programs and growth of each unit of local government affect not only that particular unit but also the activities and programs of a variety of other units within each urban area."14 Not all boundary 
changes coming before the Commission have significant spill-over or secondary effects, but those that do may simultaneously affect a multiplicity of units of government. A recent proposal (No. 1014) involved directly and actively the following institutions:

Environmental Protection Agency

State Department of Environmental Quality

Washington County Commission

Clackamas County Commission

City of Lake Oswego

Clackamas County League of Women Voters

Bonita Meadows Neighborhood Association

Southwood Park Sanitary District

Southwood Park Water District

Lake Grove Water Iistrict

The "Mormon Church"

Thus, a single primary relationship may be accompanied by a multitude of secondary relationships. Secondary relationships, either singularly or in the aggregate, may be far more important in their effect than the effect of the proposal on the unit of government engaged in the primary relationship. The terms primary and secondary reflect the source of the relationship, not the magnitude. The source of primary relationships is the type of boundary change: the source of secondary relationships is the effect of boundary changes.

Boundary changes which involve the Commission in both primary and secondary relationships lead to one kind of a third type of intergovernmental relations in which the Commission engages-intermediary. These 
intermediary relations cover a broad spectrum, ranging from cases in which the Commission acts purely as catalyst in bringing about a reaction without playing a substantive role in the reaction; to cases in which the Commission plays almost a judicial role by designing and imposing a solution upon contending parties in accordance with the mandates of the Boundary Commission Law. The Commission has occasionally acted in its purely catalytic capacity without the presence of an actual proposal. In such cases, the Commission has usually identified a developing problem and called together the relevant parties to develop a plan to head off the problem. In such cases the Commission, acting as an independent and impartial third-party, serves primarily to bring the relevant parties together, provide a forum for discussion, and guide the parties to a solution of their own making which lies within the broad confines of acceptability to the Commission. Some cases require the Commission to take more aggressive action to bring about a solution to conflict which is acceptable to the parties as well as the Commission. The following Gresham annexation case demonstrates several degrees of action by the Commission in bringing about solutione to problems between contending parties. Some points of contention required only catalytic action while the dispute between Gresham and. District 10 required more aggressive action to cause the parties to negotiate a compromise acceptable to the Commission. The second case discussed, involving fire protection in the Goble Community, demonstrates the most aggressive and active intermediary role of the Commission where it ultimately designed and imposed a preferred solution on the contending parties. In reading these, however, one 
should not lose sight of the fact that in playing its intermediary role, the Commission is not always successful in reaching its preferred outcome. The Commission often must accept a solution it considers less than optimal but within the outlines of acceptability. The Boundary Commission Law forecast the necessity of the Commission's intermediary role in its policy statement, which says: "As local programs become increasingly intergovernmental, the state has a responsibility to insure orderly determination and adjustment of local government boundaries to best meet the needs of the people. 15

In a letter to the Boundary Commission, dated December 14, 1972, Bob McWilliams, Gresham City Manager, stated:

On March 1, 1972, the Boundary Commission adopted a policy which directly requested the cities of Multnomah County (including Portland) to prepare and submit within a three-month period, a definitive boundary plan. (Multnomah County was also asked to submit a plan or statement presenting its views on future growth of the cities, as it related to their comprehensive plan for handling future unincorporated service needs.) The plan was to cover a two-year period and include, but not be limited to:

a. Uesignating geographic areas the city would like to annex;

b. Outlining the city's ability to provide services in the area;

c. Outlining the cost and method of financing extension of services to the areas;

d. Outlining the probable method of initiating annexation of each area designated.

Several cities have previously submitted their generalized spheres of influence plans to the Commission. The efforts should be refined to indicate a reasonable area of expansion (if any) that might be taken into the city through annexation procedure prior to the vote on City-County consolidation.

If the overall vote is successful and the cities of east Multnomah County choose to opt out, they should in this interim period have the opportunity to expand their boundaries within reasonable limits. The cities are in the best position to indicate what this area of growth may be and what they can reasonably accomplish in this period prior to a vote on CityCounty consolidation. A successful vote for consolidation would mean that those cities which opt out would have their boundaries frozen as of that time.16 
The City of Gresham presented the Commission a two-stage expansion plan, the first stage of which included six parcels which would add 5,000 acres and 5,166 people to the city and double its size. These six parcels were proposed for annexation by Resolution No. 623 of the Gresham City Council on June 26, 1973. By virtue of the legal jurisdiction of the Boundary Commission over annexations to cities, this action created a mandated primary relationship between the Commission and the City of Gresham. A public hearing on the proposals, numbered 617 through 622 inclusive, was scheduled for July 25, 1973.

During the period between receipt of the resolution and the public hearing, the Commission staff performed a study of the proposals which analyzed them on the basis of a number of criteria including: land use and zoning; fire service; water service; sewer service; police service; and impact on other governmental units.

Because Oregon law provides that with the exception of water and sewer districts, territory annexed to a city is automatically withdrawn from any special districts in which it is currently located, these proposals had a profound secondary effect upon Multnomah County Rural Fire Protection District No. 10, which was providing fire protection to the territory in question. 17 Under the 1 aw, the City Council may choose to remain in the district and in the case of sewer and water districts, the law provides for exchange of ownership. After the existence of these proposals became known widely, a number of other units of government felt themselves to be secondarily affected and made those feelings known to the Commission. Thus, the secondary effects of these proposals created secondary relationships between the Commission and a number of 
units of government including: School District No. 28; Rockwood, Powell Valley Road, and Lusted Water Districts; Multnomah County and Rural Fire Protection District No. 10. Nultnomah County engaged in a secondary relationship with the Commission on these proposals because of what the Multnomah County Division of Land Use Planning perceived as conflicts between the City of Gresham's land use projections for the area and the existing Iand use for the area as defined by the County Comprehensive Plan. ${ }^{18}$ CRAG also felt that one of the proposals, No. 618, was in conflict with the CRAG Interim Development Policy Guidelines for Development, and recommended its denial. ${ }^{19}$ on the basis of information contained in the staff report, and received from those engaged in secondary relationships, and the public hearings held on July 25 and August 22, the Commission took official action to close public hearings on the proposals and to defer a decision on the proposals,

- - until such time that the Commission is assured that:

1. The level of fire service provided in the City, and the territories to be annexed is at the level presently provided in the urban and urbanizing portions of Rural Fire Protection District No. 10; and

2. The proposals are evaluated against the objectives of the proposed CRAG Interim Development Policy and the Commission is assured that the proposals meet those objectives. 20

When the Commission found itself engaged in primary and secondary relationships which were in conflict, it responded by developing the third type of relationship-intermediary-with respect to those units of government whose positions on the annexations were conflicting. In his letter to the Fire District and Gresham, Chairman Tippens extended the following comments:

The Commission members earnestly hope that a workable solution can be achieved between the City and District so that it can continue with the review of the City's boundary program. The 
Commission stands ready to provide whatever assistance is needed to bring this matter to a successful conclusion: should either or both parties desire it, we will be glad to call joint meetings of both units. 21 ,

"This offer of "good offices" must be viewed in light of the situation existing between the City and the District in order to appreciate the importance of the intermediary relationships to all of the parties.

In the past, the City had mutual aid agreements with Districts No. 10 and No. 14, the Port of Portland and the City of Portland. Based on their perception that Gresham had not been willing to upgrade its fire service to a point where it could hold up its end of mutual aid, these other departments had terminated the agreement. 22 By August 15, 1973, no other fire department would respond to any fires within the City of Gresham. The City of Gresham countered that this was an attempt to force the City to consolidate with District 10 and that the City offered adequate service which would become even better in the near future. 23 Attempts at bilateral negotiations had reached a stalemate and communication between the parties had broken off even before these proposals reached the Commission. The staff report had supported the position of District 10 and found that the fire insurance rating in the territory would drop from five to six if served by the City. ${ }^{24}$ The Commission, in turn, advised the parties that it preferred consolidation as a solution. After a series of letters between the City, the District, and the Commission, the City and the District agreed to reopen negotiations. Meanwhile, the Commission was also engaging in intermediary relationships between Gresham and CRAG and Gresham and Multnomah County with respect to land use conflicts arising from the proposals. These conflicts had no acrimonious history similar to that with the lire 
District and the good offices of the Commission soon brought the parties together.

In a letter to the Commission, dated January 31, 1974, the governing body of the City of Gresham notified the Commission of the following:

3. Representatives of Fire District No. 10 and liultnomah County and the City of Gresham have arrived at a very satisfactory working relationship for providing fire service. Included as an enclosure is a copy of the Letter of Intent which will bind the two parties to immediately begin the program without waiting for the Attorneys of the two entities to prepare the formal agreement. As there is no question that this program is adopted and is being implemented, it seems that this should satisfy your Board and that it can act on the Ietter of Intent.

In addition,

4. The City has met with representatives of CRAG and lul tnomah County. Mr. Carlson of your office was in attendance at that meeting. Agreement was reached that the City should not, at this time, annex certain areas because of the possible conflict with the CRAG Interim Regional Development Policy. Therefore, we are including a map and new legal descriptions which will cause boundaries of the Phase I, Stage I annexation to change.

At its meeting on February 6, 1974, the Boundary Cumission on the recommendation of the staff, approved proposals $617,619,620,621$ and 622 as submitted and 618 as modified. This case illustrates both the purely catalytic and the more aggressive types of the Commission's intermediary relationships. With respect to some points of contention the Commission simply facilitated the reactions between the parties. Given the corrosive relations between the City and District 10, it is doubtful that without the aggressive action of the Commission, there would have been any solution of the conflict. Not all intermediary action results in conclusions which conform to the Commission's 
preferences. In proposal No. 1014, the most complex case ever before the Commission, the Commission worked diligently as an intermediary to bring about a preferred outcome which it ultimately was unable to achieve. As a result, it had to approve an action which it considered to be a less than optimal solution to the needs of the area in question. To repeat, this case illustrates the three types of intergovernmental relationships in which the Boundary Commission participates. First, the mandated primary relationship with the City of Gresham based upon legal jurisdiction over a type of boundary change, annexations to cities. Second, the secondary relationships with Rural Fire Protection District No. 10, CRAG, Multnomah County, various water and school districts, and others based upon the effects of the boundary change. Third, the intermediary relationships in which the Commission operated between the city of Gresham and CRAG and Multnomah Counties, respective$1 y$, and between the City and RFPD No. 10.

From the spring of 1972 until the spring of 1974, the Portland Commission was involved with a case which centered around the issue of fire protection for a rural area in Columbia County known as the Goble Community. As we shall see, the case illustrates the kinds of circumstances under which the Commission takes a more forceful role in acting as an intermediary between contending factions.

The case began with a petition received April 24, 1972 proposing the creation of the Goble Rural Fire Protection District. The "Staff Report" on proposal 429 described the area:

The territory to be formed as a rural fire protection district is located in Columbia County between the St. Helens RFPD to the south and Rainier RFPD to the north. The territory contains approximately 31 square miles, 300 single family dwellings, 
three commercial structures, one industrial plant (the Trojan nuclear power plant), one school, two churches, a county road equipment building, and an estimated population of 1,180 persons. tixcept for the portion of the territory along the Columbia River Highway, most of the territory is made up of hills and ravines with scattered timber and brush.

At the time of the petition, the area was without any kind of effective fire protection. What service there was came from the City of Rainier on an "on call" basis and the fire insurance rating for the area (10) was the lowest possible rating. "On call" meant that the Rainier Fire Department would respond at its option but was under no legal or contractual obligation. Because of the local topography, which was hilly, and the poor condition of the roads, which were described as narrow, curvy, steep, and unsurfaced, it was impossible to provide fire protection with a reasonable response time of five or ten minutes without locating a truck and station on the top of a centrally located hill in the Goble Community. In order to provide such a facility, the petitioners proposed a volunteer fire department with a pumper and a tanker truck. The proponents estimated the need for an $\$ 80,000$ bond issue to pay for the construction of the station and the purchase of trucks and a $\$ 10,000$ yearly operating budget. The proponents suggested a tax levy of $\$ 18,000$ per year to finance the operation of the district and the bond and interest payments. Given an estimated assessed value of the area within the proposed district of $\$ 15,693,337$, the tax rate would have been about $\$ 1.14$ per $\$ 1,000$ of true cash value (TCV). 25 Because $\$ 8,795,000$ of the assessed value of the district was the Trojan nuclear power plant, the estimated tax rate for the district, not including Trojan, would have been about $\$ 2.60$ per $\$ 1,000$ TCV. 26 This figure of $\$ 8,795,000$ was for the partially completed project. 
Throughout this case, the commissioners operated on the assumption that the completed Trojan plant would assess between 40 and 50 million dollars.

In its recommendations to the Commission on proposal No. 429, prepared prior to the first public hearing held June 14, 1972, the staff arrived at the following conclusions and recommendations:

The staff recommends that Proposal No. 429 be deferred for the following reasons:

1. The Goble RFPD could not be viable without the assessed value of Trojan.

2. The assessed value of Trojan ought to be of benefit to the entire area affected by the plant.

3. Fire protection ought to be area wide in scope for the area and ought to include the area in tine Goble proposal plus the area currently being served by the Rainier city and rural fire districts.

4. The Boundary Commission staff should take part in meetings between the affected parties to effect the steps outlined in this report.

5. A comprehensive area wide fire protection service including Trojan is the best alternative for fire protection in the area. 27

It was the opinion of the staff that the proposed district would not be economically viable if the Trojan plant were removed from the district. Without the plant, the tax rate necessary to create and operate the district would be double the rate with the plant and double the rate necessary to create and operate a consolidated district which could include Trojan. The staff also felt that the district without Trojan would simply be too poor and too small to provide effective fire protection regardless of the tax rate. The staff believed that there was a threshold size for fire districts below which effective service cannot be provided, because there is a minimum financial capability imposed by the cost of equipment. "A $\$ 30,000$ fire truck costs $\$ 30,000$ regardless of the size of the district." ${ }^{28}$ The staff was convinced that 
the Goble District without Trojan was below this threshold.

On June 7, the Commission received a letter from Portand General Electric Company (PGE), operators of the Trojan plant, requesting the removal of the Trojan plant from the proposed district. PGE based its request on the grounds that:

The Trojan project now has, and will have during all of the construction stage, an extensive system of pipes, pumps, hydrants and hose for fire protection, coupled with a substantial number of portable fire extingiashers . . .

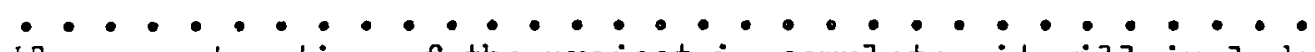
When construction of the project is complete, it will include elaborate and specialized fire protection equipment built into the various buildings and components of the working part of the plant. In addition, the plant crew will be technically knowledgeable as to the appropriate procedures to be employed in the event of a fire in these facilities. 29

In order to further buttress its request not to be included in the proposed Goble District, PGE stated that, "nevertheless, there may be need for supplemental protection and we have therefore entered into a contract with the City of Rainier for standby fire protection." 30 The staff rejected the PGE argument, as the second staff recommendation indicates, on three grounds. First, the staff was of the opinion that the existing contract with the City of Rainier demonstrated there did exist a need for additional fire protection. The staff also doubted the PGE claim because it had often been its experience to find large industrial concerns making the same argument when it was clear the fire district they were in had men specially trained and equipped to deal with fires at that plant. Secondly, Ken Martin had conducted a survey of such nuclear power plants located around the country and found that it was not uncommon for such installations to be within local special districts. In addition, the plant was already within the local school 
district. Ihirdly, having determined that Trojan needed outside fire protection and that such nuclear power plants were commonly within special districts, the staff was of the opinion that the tax base provided by the plant ought to be utilized by all of the area affected by the plant. 'The staff believed that much of the population growth of the area and the development of secondary and tertiary industry in the area was attributable to Trojan and that areas impacted by this growth ought to have proportionate access to the plant's tax base to help cover the costs of increasing service demands. Thus, the tax base of Trojan for fire protection purposes ought not be confined solely to the Goble area as would be the case under the proposed Goble District. The third recommendation, that there ought to be a consolidated area wide system of fire protection for the areas including the Goble proposal and the area currently being served by the Rainier city and mural fire districts, was based upon a staff analysis of the costs of providing fire protection for the consolidated area at a qualitative level equal to or better than that existing or proposed for each area. At that point, the staff cost analysis for such a district, including Trojan, was $\$ 1.02$ per $\$ 1,000$ TCV which was less than the estimated cost for the proposed Goble District, including Trojan, of $\$ 1.14$ per $\$ 1,000$ $\mathrm{TCV}$, and provided estimated class 8 protection rather than the estimated class 9B protection of the Goble District proposal. Thus, the staff was convinced that a consolidated area wide district would best assure adequate quantity and quality of service while at the same time maximizing the economic and financial viability of the district and preventing further fragmentation of local government. To achieve these 
ends, the staff proposed in recommendation 5 that they be given the assignment of reaching a consensus among the affected parties.

Having carried out the study of the original proposal, the staff was not unaware of the difficulties they would face in trying to bring about such a solution. The original petitioners had received a copy of the staff report and came to the June 14 public hearing prepared to rebut the staff contentions and, in making their presentations, they made it clear what the environment would be like in which the staff would be acting as intermediaries. With respect to the question of area wide consolidation and cooperation, the following quotes from the prepared statement of Mary Johnson who had spearheaded the Coble District proposal are very illuminating.

I am against annexation to any district and in particular the Rainier Fire District.

Also during this time, I had been talking to the residents of the area. Both the old timers and new residents wanted their own district. It seems they have had problems with Rainier over school consolidation and have very strong anti-Rainier feelings. The most often quoted statement being 'We're better off with nothing than to annex with Rainier.

I also called Mir. Carlson and talked with him about local problems. Mr. Carlson was the only one who recommended we annex to Rairier and his reason was to make the people work together and to eliminate a governing board of directors. Although I agree with Mr. Carlson that the communities should forget their quarrels and work together, I have found in the past few months that at the present time cooperation between the two communities is near impossible. It boils down to the old saying, 'you can lead a horse to water but you can't make him drink.' If we are annexed to Rainier we will have a district but will still have no protection because the voters will rebel and fight because their wishes were ignored.

She reported that on two occasions there had been votes at community meetings on the choice of forming an independent district or joining Rainier and that the district had been preferred on both occasions by votes of 19 to 4 and 46 to 4 . 
I did not try to influence the people, their minds were made up long before they heard of me. Liven though I asked people to read the petition and watched them read it they still asked me, and I quote, 'you sure this doesn't have anything to do with Rainier? If it does, I won't sign it.' 'The people absolutely refuse to help if annexed to Rainier but will work their tails off for our own department and district.

The difficulties alluded to with respect to school consolidation were, in the opinion of the staff, the seed from which the intense illwill on the part of Goble residents toward Rainier had blossomed and to outsiders like the Commission staff appeared incredibly petty. 'The specific situation involved a school bus which had been newly purchased by the Goble School District shortly before consolidation with the Rainier School District. As the Commission staff understood the story, after the consolidation the new bus was assigned a route within the old Rainier District while the Goble route was assigned one of the old buses that had been serving a Rainier route. Thus, the Goble residents had become convinced that the Rainier people could not be trusted and that Goble would come out on the short end of any kind of arrangement with Rainier.

At the first public hearing on June 14, the Commission discussed with the petitioners and others the Trojan situation and how the Trojan tax base ought to be distributed, if at all. In response to a direct question from Tony Federici, the petitioners announced that they were willing to exclude 'Trojan if necessary to obtain their own district. This served to give force to the animosities because it demonstrated to the staff that the petitioners were willing to double their tax rate for fire protection in order to avoid dealing with Rainier. The Commission continued the proposal until July 12, 1972. 
In the interim, the Commission staff sent letters to all of the existing providers of fire protection in the same general area request ing comment on the feasibility of a consolidated district and asking that specific proposals be made. The same requests were made of the State Fire Marshal's Office and the Insurance Rating Bureau. Petitioners indicated that both of these organizations had recommended the establishment of an independent district. In their letters to the Commission, however, they expressed a general preference for a consolidated area wide system. 31 The St. Helens Rural fire Protection District initially expressed some interest in serving the Goble area but later withdrew. 32

At the July 12 hearing, Mary Johnson again presented a prepared statement for the petitioners. After defending the inclusion of Trojan within the proposed district she again reiterated their willingness to do without Trojan, if necessary, and raised the spectre of the school bus affair in delivering an ultimatum to the Commission.

If, for any reason, you still feel Trojan should be left out of our proposal, then we ask that you let us have our own district without them.. . we want to be left alone or be left out. We would rather have nothing at all than be paying taxes for someone else's new equipment while they pawn off their old stuff on us. If our taxes are going to get new equipment, it is going to be our own, for our area. We wish to thank you for hearing us out and again we ask either let us have our own district, with or without Trojan, or deny us a district altogether.

The next person to speak was the mayor of Rainier, Charles E. VanGorder, who read a statement containing the only positive response to Carlson's request for proposals. James Mason, City Attorney for Rainier, had presented the Commission with a tentative budget for a combined Rainier Rural Fire Protection District which would include the 
City of hainier, Rainier RFPD, Goble area, and Trojan. He estimated that such a district could operate for about $\$ 1.00$ per $\$ 1,000 \mathrm{TCV}$. While expressing satisfaction with the present fire protection system in the City, he expressed a willingness on the part of the City to join in a larger consolidated district. Mayor VanGorder stated that the City wanted to see the development of a consolidated mural fire protection district to which the City could annex. The City wanted out of the business of providing fire protection service. Mason requested additional time to develop the proposal further, and the Commission took the appropriate action by continuing the proposal until the August 9, 1972 meeting.

At the meeting on August 9, the Commission and Mayor VanGorder engaged in a dialogue about the details of the plan which Rainier had developed for a consolidated district, and it is clear from the record that the proposal for an independent district was dead because the conversation dealt exclusively with the area wide approach. By August 9, the Commission had only 22 days in which to act on proposal No. 429 before the 120-day limit was up and it would not meet again during this period. Therefore, in order to prevent the 120-day period from lapsing before making a decision, an occurrence which would return the proceeding to the principle act as though it had been approved by the Commission, the Commission denied proposal No. 429. In the Final Order, the Commission laid out its reasoning in rejecting the independent district and its reasons for preferring an area wide approach. The record of the August 9 meeting and the language of the "Final Report" indicate that the Commission believed that it would only be a short 
period of time before they would receive a formal proposal to create the consolidated area wide rural fire protection district which they had discussed at length. The significant findings included the following points:

d. The only practical way to provide service to the area is to have an engine housed up on the hill within the heart of the Goble area;

e. The petitioners proposed to buy a used truck and man it with an all volunteer force;

f. The City of Rainier and the Rainier RFPD presented an alternate proposal for an area wide fire protection program including the territory of proposed No. 429 which would allow for a full time chief and a new engine for the Goble area;

g. The Commission felt that setting up a small district for only the Goble area would be inconsistent with the philosophy under which the legislation set up the Boundary Commission Law . . that philos phy expressing a need for forming and encouraging only viably feasible special districts;

h. The Commission feels that Goble district by itself could not be a viable unit if it did not include the Trojan plant and the Trojan plant should only be included and taxed for the support of an area wide fire protection system;

j. The Boundary Commission states that it fully understands the necessity for a substation in Goble no matter what solution is ultimately adopted for the area and declares that this would be of paramount importance to any proposal coming before it which offers fire protection to the area;

1. The Boundary Commission felt that the alternative proposal presented by the City of Rainier and the Rainier RFPD was a more logical and viable solution and would offer better fire protection to the residents of Goble.

This concluded the first stage of the development of the fire protection system for the Goble Community. At this point, the Boundary Commission had not engaged in any extraordinary activity with respect to this situation. It had engaged in all three of the roles mentioned earlier. It had engaged in a primary relationship with the Goble petitioners. It had engaged in secondary relationships with the City of 
Rainier, City of Prescott, Rainier RFPD, and the St. Helens RPPD. It had carried out a study of the proposal and as a result of that study, had concluded the proposal was inadequate. It had then engaged in an intermediary relationship among the affected parties in an attempt to assist them in developing a proposal which would be satisfactory to each of them individually and also allow the Commission to maximize the attainment of the goals and objectives which are set for the Commission by the Boundary Commission Law. At the time the Commission denied proposal No. 429, it felt it had not only denied a proposal but at the same time assisted in the development of a soon-to-be proposal which would solve the larger problem of fire protection for the whole area. They waited.

On November 27,1972 , a Iittle more than three months after the denial of No. 429, Don Carlson sent a letter to Mary Johnson informing her that: "I just read an article in The Chronicle concerning the endeavors of you and your fellow committee members to create the unified fire district. From the tenor of the article it sounds as if your efforts are paying off." The Boundary Commission, represented by Carlson and Tony Federici, had met with the local residents at the Rainier City $\mathrm{Hall}$ in October of 1972 and had explained to those assembled the details of the consolidated plan which had been developed as the alternative to No. 429. At that meeting, the Commission attempted to demonstrate to the Goble residents that the new plan would provide them better fire protection at lower cost than would have No. 429. They specifically pointed out that Goble would have a substation with new trucks and that Rainier would be served by its present 
stations with its present trucks. At the October meeting, a committee was formed with all areas represented, to study the cost of a consolidated district, and subcommittees were assigned specific subjects to research. In spite of the remaining ill will among the local communities, the development of the proposal seemed to be moving along. They waited.

This committee did eventually come up with a proposal to expand the Rainier RFPD to include Goble, Apiary, Fern Hill, and the cities of Rainier and Prescott as well as the Trojan plant. The committee felt, however, that before they could ask area residents to sign petitions to annex to the Rainier RFPD, the fire district board should agree in principle to the proposal and the committee submitted it to them in May, 1973. The Board took no action. The Commission staff is of the opinion that even if the Rainier RFPD had been enthusiastic supporters of the general principle of an area wide district, this proposal would have received a cool reception. This was because the proposal still reflected the distrust among the local communities and was accusatory in tone and rife with ultimatums. In addition, "it was crude, it lacked sophistication, it focused on only a few points of concern and was tactless and undiplomatic. No one involved in putting it together was experienced in such work." 33 In short, there was no attempt at compromise or consensus.

Had there been, there is still no reason to believe the action, or in this case inaction, of the Rainier RFPD Board would have been any different. To begin with, the Board consisted of "five of the oldest men I had ever seen," according to Ken Martin, "who had no interest in 
changing anything." 34 They had good reason not to want to see any changes made. The Rainier RFPD had no employees and no equipment. It was simply a legal entity which purchased its fire protection from the City of Rainier by contract. For years, the district had paid a disproportionately smaller share of the cost of their protection than City residents themselves. For the year ending July 1, 1973, the District paid a tax of 22 cents per $\$ 1,000$ TCV while City residents paid $\$ 2.12$ per $\$ 1,000 \mathrm{TCV} .35$ Yet at least half of the fire calls answered by the Rainier City Fire Department during that year were in the Rainier RFPD. The District had been notified by the City that its cost would be increased to about 90 cents per $\$ 1,000 \mathrm{TCV}$ for 1974. Nevertheless, the District was paying substantially less for fire protection than anyone else in the area and even the increased rate was below the estimated costs under the area wide proposal. Thus, one of the major participants, the Rainier RFPD, had no reason to desire a change of any kind.

The last major participant, the City of Rainier, had features which both added to and detracted from the likelihood of consolidation. The Rainier Fire Department did not have a full time chief or full time employees. This removed one of the normal obstacles to consolidation, an entrenched staff and officialdom. On the other hand, there was nothing to really push them toward consolidation either. The City was satisfied with the fire protection it was getting from its own department and with its new arrangement with the Rainier District and the City of Prescott which it also served under contract. The City of Rainier also reciprocated the enmity which the Goble residents felt towards them and contributed to the difficulties of designing a proposal by making 
claims which further poisoned the relationship. At one point, the City was demanding that the new district, if created, would have to buy out the City's financial interest in plant and equipment. The Boundary Commission staff perceived the position of the Rainier City Council to be one of intense indifference; they simply did not care very much. When one looks at the environment in which the proposal was supposed to germinate, it is not surprising that there was very little, if any, growth. The Goble Community disliked and distrusted Rainier, the Rainier District, and the Boundary Commission. The Rainier RFPD with its gereatric Board trusted no one and had no incentive to change the status quo. The City of Rainier trusted no one and had no incentive to change things either. The only thing the three major participants shared in common was a mutual distrust of the Boundary Commission. Another factor contributing to the slow development was the lack of local leadership. Ken Martin is of the opinion that if one well known community leader, someone with standing in the community, had taken an active role in support of the area wide district, it would have come into being before tragedy struck. For it took a tragedy to really get things moving again. 36 As the months went by without a proposal, it became clear to the Commission that the residents of the area cared more about preserving their "independence" and perpetuating their poisoned relationships than they did about providing adequate fire protection to the area.

It took the death of a child to convince at least some of those involved that the price they were paying for their independence was too high. A house fire in the Goble Community had caused the death of a 
young girl. The Rainier District was called after some delay and did not respond because the fire was outside the District and because it estimated too much time had elapsed to make their response feasible in terms of being able to control the fire. The fire and fatality had two apparent impacts. First, it brought to light the length of time since the Commission had denied No. 429, since it was now September, 1973, and the absence of any viable proposal for formation of the area wide district. Secondly, it further heightened the animosities between the people in Goble and those in Rainier. On October 11, 1973, the Commission staff informed the Commission that,

- . it is highly unlikely that a proposal for an area wide fire system will be forthcoming from the people or governmental entities in the Rainier area. It is the staff's feeling that an expanded area wide fire system is of critical importance to the people of the entire area and that initiation should come from the Boundary Commission. 37

The Commission staff had concluded that the passive intermediary role, in which they attempted to bring the contending parties together so that the parties themselves could work out an acceptable solution, had not succeeded. It was time for the Commission to begin to play a much more aggressive intermediary role, one in which the Commission itself takes a much more active part in developing the proposal which itself, in turn, initiates.

On September 6, 1973, the following letter was sent to the Chairman of the Board, Rainier RFPD; Mayor VanGorder of Rainier; and Mary Johnson of Goble, over the signature of Jerry Tippins the Chairman of the Boundary Commission.

It has been more than a year now since the Boundary Commission denied formation of a new fire district in the Goble area in favor of the creation of a larger area wide fire district 
encompassing the City of Rainier, the present Kainier Rural Fire Protection District and the Goble area. It is the Commission's understanding that the committee formed by local residents of the three areas involved has completed a plan for the unified district, but no action has been taken to bring the plan into reality.

Also, we have been informed that there has been a recent fire in the Goble area which resulted in a loss in life. The members of the Commission deeply regret the recent tragedy and feel that immediate steps must be taken to insure that the entire area obtains a reasonable level of fire protection. Consequently, our staff has been instructed to undertake an immediate investigation to develop a program that the Commission can follow to initiate and implement the plan for an area wide fire system.

I will ask the Commission to devote its full attention to this matter so an early solution can be reached.

I trust that all parties involved can work together to build a good, efficient and effective fire defense system.

About a month later, on October 17, 1973, the Commission adopted Resolution No. 23 which initiated the annexation of Rainier, Prescott, and the Goble, Ferm Hill and Apiary areas to the Rainier RFPD. 'ihis would add about 60 square miles and 5,000 people to the existing District. What occurred after the passage of the Resolution is far less complex than the earlier history of the proposal. Stated simply, Ken Martin developed the proposal. He conferred with the other people involved from time to time while developing the proposal but he did not rely on them to prepare any of the propesal itself. The basic outline of the proposal already existed, but Martin had to fill out this skeleton with specific material, much of it highly technical, and the proposal itself runs to fourteen pages. The Boundary Commission not only had assumed the responsibility for initiation but it had also assumed the responsibility for developing the proposal as well. In this case, it meant the designing of a RFPD right down to the last nut and bolt by its own staff. 
Ken Martin recalls that this project was even more demanding than it might have otherwise been because he felt the proposal would have to accomplish three important objectives. First, he felt it would be necessary to develop a very detailed blueprint which the leaders of the new district could follow in implementing the plan. Secondly, he felt that the blueprint would have to meet very high standards to demonstrate to the City of Rainier and the Rainier RFPD that the Boundary Commission was competent to design a fire district and that this particular proposal was a feasible plan. If he succeeded in doing so, it would greatly increase the likelihood that the cities would pass resolutions annexing to the District and that the Board of the Rainier District would accept the plan. Thirdly, he felt he had to convince the citizens of Goble that the plan was competent, would treat them equitably and meet their basic demands. He felt that if he could do so he could avoid the possibility of a remonstrance. He was constantly aware that the Boundary Commission was not trusted by any of the participants to be either fair or competent. 38

The first of two public hearings on the new proposal, No. 663, was held in Rainier on January 16, 1974. Both the City of Rainier and the Rainier RFPD were well represented, but there was no one there to speak for the Goble Community. While the Commission is of the opinion the fatality fire gave them a strong moral basis for demanding local action, if not a legal basis, the record of the meeting demonstrated the perseverence of the animosities. After an extended session in which the major points of controversy were between the City of Rainier and the Rainier RFPD and consisted of two major issues: distribution of costs 
for the existing City of Rainier plant and equipment; and representation for the new areas on the Board of the Rainier RFPD, the City and the RFPD agreed to meet and settle the issues prior to the next Commission meeting on February 6, 1974. Their willingness to do so was probably heightened by a statement by Chaiman Tippins that the Boundary Commission would like to get this resolved by the February 6 meeting. Another issue of considerable controversy which was not yet resolved at the conclusion of the meeting was the inclusion or exclusion of the Trojan plant. Generally, the area residents wanted the entire Trojan facility in the district and PGE wanted a contractual agreement.

By February 6, these problems had been settled by negotiation between the affected parties. The City of Rainier had dropped its demand for compensation and the Rainier RFPD Board agreed that four of its five directors would resign at the first meeting of the new district so that new members could be appointed from the new areas. The Board of the RFPD and PGE had worked out a contractual agreement satisfactory to both parties. This agreement, however, caused the Commission some concern and became the only item of controversy among the commissioners themselves. ijevertheless, the proposal was approved 6 to 3 with the controversial Trojan contract included intact.

It had taken six months to implement the area wide fire district once the Boundary Commission had decided to take greater initiative and develop a specific proposal using its own staff resources and judgment. It had taken this action for two basic reasons. It had been over a year since the denial of No. 429 and in spite of the intermediary efforts of the Commission, it was clear that no proposal was likely to come from 
the affected parties in the near term. The Commission and the staff were convinced that there would be no fire protection for the area in the near future unless the Commission itself acted aggressively to develop and act upon a proposal which it would itself initiate. Secondly, the fatality fire had caused many of the comissioners and the staff to feel partially responsible. Both of these factors lowered the Commission's inhibitions against substituting its judgment for that of the affected parties. The death of the child also caused the fire protection issue to resurface in the local area. The issue of fire protection had long been submerged by the local jealousies and animosities and the child's death raised fire protection to its proper level by causing both the local residents and the Commission to realize that the lives of people were more important than their now petty rivalries.

Figure 1 attempts to illustrate these intergovernmental relationships through the metaphorical use of a spoked bicycle wheel. The Boundary Commission Law, like the hub of a wheel, is at the center of the structure and provides the basic support. Along the rim of the wheel lie the units of government which are tied to the Commission and to one another through the three types of intergovermmental relations. One set of spokes is formed by primary relationships and the other set by secondary relationships. The rim which connects the units of government together is formed of intermediary relationships. As in the wheel itself, the primary and secondary spokes are subject to tension and this tension supports the structure. A wheel consists of a set of component parts which are combined in certain relationships to form a structure 


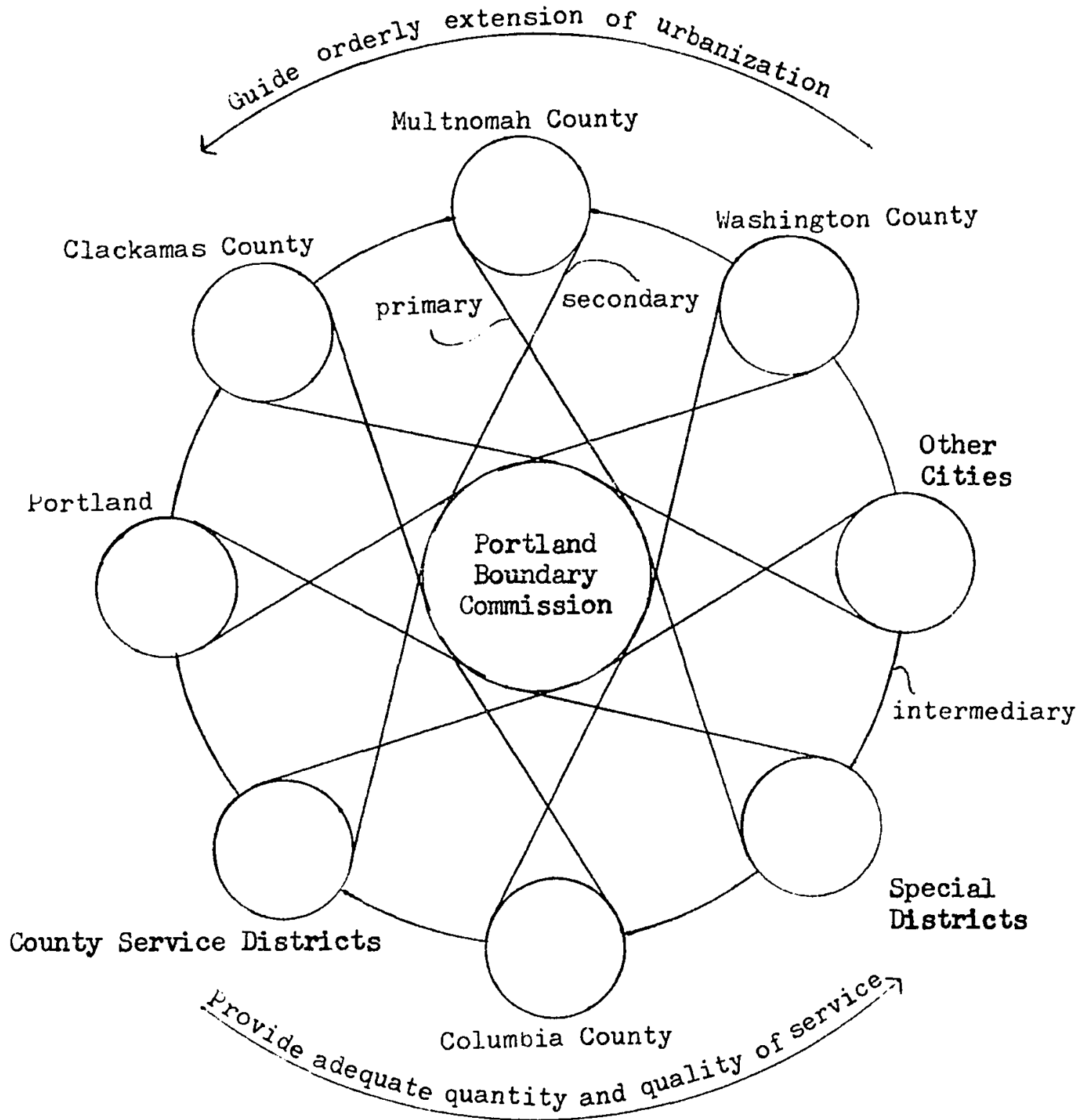

Flgure 1. Boundary Commission intergovernmental relations.

capable of functioning as a wheel. It is the inter-relationships of the parts and not the intrinsic properties of the parts which creates the functioning wheel. The Boundary Cormission structure al so has a function which is the result of the relationships between the component parts and cannot be performed by the components outside of the 
relationship. Take any one part from the wheel and it no longer functions. Take any one part from the Boundary Commission structure and it could no longer fulfill its functions: to guide the orderly extension of urbanization and provide for an adequate quantity and quality of urban services. 


\section{FOOTNOTES}

1. Portland Boundary Commission, "Biennial Statistical Summary," December 1, 1977, Portland, Portland Boundary Commission files.

2. Don Carlson, Private interview, Portland, March 20, 1978.

3. Oregon State Legislature, Senate Joint Resolution No. 56, 1977.

4. Don Carlson, Private interview, Portland, April 4, 1978. Frank Roberts, Private interview, Portland, April 7, 1978.

5. Portland Boundary Commission, Letter to Representative Glen Otto regarding conflict between Iusted water District and the City of Gresham, February 16, 1978, Portland, Portland Boundary Commission files.

6. Oregon, Executive Department, Organization of Oregon State Govermment. (Salem, November, 1977).

7. Don Carlson, Private interview, Portland, April 4, 1978.

8. Portland Boundary Commission, "Policy on Land Use and Coordinated Planning," May 20, 1970, Portland, Portland Boundary Commission files.

9. Ibid.

10. Columbia Region Association of Governments, Memorandum to Don Carlson concerning CRAG review of proposed boundary changes, September 10, 1973, Portland, Portand Boundary Commission files.

11. 279 OR 249 (1977). Chapter 644, Oregon Laws, 1977, Vd 1, Oregon Legislative Assembly.

12. Oregon Laws, 1973, Vd I, Oregon Legislative Assembly, p. 133.

13. Portland Boundary Commission, "Biennial Statistical Summary," December 1, 1977, Portand, Portland Boundary Commission files.

14. ORS $199.410(b)$.

15. ORS $199.410(\mathrm{c})$.

16. Portland Boundary Commission, "Staff Report" on proposals Nos. 617, $618,619,620,627,622$, City of Gresham annexations, July 25, 1973, Portland, Portland Boundary Commission files. 
17. ORS 199.462(a). ORS 199.510(b).

18. Robert S. Baldwin, Letter from Robert S. Baldwin, Planning Director, Multnomah County, to the Portland Boundary Commission, December 17, 1973, Portland, Portland Boundary Commission files.

19. Lyle E. Balderson, Letter from Lyle E. Balderson, Area Development Director, CRAG, to Portland Boundary Commission, December 10, 1973, Portland, Portland Boundary Commission files.

20. Jerry Tippins, Letter from Jerry Tippins, Chairman, Portland Boundary Commission, to Gresham City Council and RFPD No. 10 Board of Directors, August 28, 1973, Portland, Portland Boundary Commission files.

21. Ibid.

22. Portland Boundary Commission, "Staff Report" on proposals Nos. 617, $618,619,620$, 621, 622, City of Gresham annexations, July 25, 1973, Portland, Portland Boundary Commission files, p. 4.

23. Bob Iicivilliams, "Reply to Boundary Review Boand Staff Report Stage I, Phase I Annexation," August 22, 1973, Portland, Portland Boundary Commission files.

24. Portland Boundary Commission, "Staff Report" on proposals Nos. 617, $618,619,620,621$, 622, City of Gresham annexations, July 25, 1973, Portland, Portland Boundary Commission files, p. 5.

25. Portland Boundary Commission, "Staff Report" on proposal No. 429, May 25, 1972, Portland, Portland Boundary Commission files.

26. Ibid.

27. Ibid.

28. Ken Martin, Private interview, Portland, August 2, 1978.

29. Portland General Electric Company, Letter from Portland General Electric Company to Portand Boundary Commission, June 7, 1972, Portland, Portl and Boundary Commission files.

30. Ibid.

31. D. F. Wagner, Letter from D. F. Wagner, Insurance Service Office of Oregon, to Don Carlson, July 7, 1972, Portland, Portland Boundary Commission files.

32. Ray Wallis, Letter from Ray Wallis, Secretary-Treasurer, St. Helens RFPD to Portland Boundary Commission, June 30, 1972, Portland, Portland Boundary Commission files. Robert R. Vagt, Letter from 
Robert R. Vagt, Attomey for St. Helens RFPD to Portland Boundary Commission, Portland, Portland Boundary Commission files.

33. Ken Martin, Private interview, Portland, August 2, 1978.

34. Ibid.

35. Portland Boundary Commission, "Proposed Rainier Area Wide Fire Protection System," October 1I, 1973, Portland, Portland Boundary Commission files.

36. Ken Martin, Private interview, Portland, August 2, 1978.

37. Portland Boundary Commission, "Proposed Rainier Area Wide Fire Protection System," October 11, 1973, Portand, Portland Boundary Commission files.

38. Ken Martin, Private interview, Portland, August 2, 1978. 


\section{CHAPTER VI}

THE POWERS AND CASES

The Boundary Commission has jurisdiction over certatn kinds of boundary changes within an area comprising Clackamas, Multnomah, Washington and Columbia Counties. In addition to boundary changes "in fact," the Commission has jurisdiction over boundary changes "in effect" such as the addition of functions to county service districts and special districts and the creation and extraterritorial extension of public and private sewer systems and the granting of service boundaries to private community water systems. Boundary changes "in effect" are those actions which do not actually modify existing boundaries but have the same effect as actions which do. As an example, the addition of a function to a county service district does not involve a physical boundary change, but it has the same effect as the creation of an additional district with boundaries contiguous to the existing district and the creation of county service districts is a boundary change "In fact" over which the Commission has jurisdiction.

The Boundary Commission Law distinguishes between two types of boundary changes: major and minor. Considered as "major boundary changes" are proposals for formation, consolidation, merger, or dissolution of a city or district. ${ }^{1}$ Proposals for the annexation or disconnection of territory to or from a city or district or transfer of territory between like units are considered "minor boundary changes. $n^{2}$ 
All major and minor boundary change proposals concerning the types of local government shown in Table III along with their principal acts, are presently under boundary commission jurisdiction.

\section{TABLE III}

\section{TYPES OF GOVERMMENTS UNDER BOUNDARY COMMISSION JURISDICTION AND THE PRINCIPAL ACTS UNDER WHICH THEY OPERATE}

Type of Government

City

Water District

Park and Recreation District

Metropolitan Service District

Highway Lighting District

Sanitary District

Sanitary Authority

County Service District

Vector Control District

Rural Fire Protection District

Geothermal Heating District
Principal Act

ORS Chapters 221 and 222

ORS Chapter 264

ORS Chapter 266

ORS Chapter 268

ORS Chapter 372

ORS 450.005 to 450.245

ORS 450.705 to 450.980

ORS Chapter 451

ORS 452.020 to 452.180

ORS Chapter 478

ORS Chapter 523

Methods of initiating boundary changes vary according to the type of government involved and the nature of the proposal. The speciffcation of methods and procedures of initiating major boundary changes relating to special districts is contained within the District Boundary Procedure Act which was enacted by the 1971 Legislature. ${ }^{3}$ Requirements for initiating major boundary changes for cities are found in Chapters 221 and 222, ORS. The Boundary Commission has the ability under the Boundary Commission Law to initiate any type of major boundary change. When a major boundary change is inftiated, the proceedings under the principal act are suspended for 120 days during which period the Boundary Commission may act upon the proposal. If the Commission denies the proposal, the proceedings stop. If the Commission approves the proposal, the proceedings return to the principal act which also occurs 
should the Commission fail to act within 120 days.

Methods of initiation of minor boundary changes are stipulated both within the Boundary Commission Law and elsewhere. 4 Minor boundary changes of all types may be initiated by resolution of the governing body of the affected city or district, by a petition signed by at least 10 per cent of the registered voters in the area to be annexed or withdrawn, by a petition signed by owners of at least 50 per cent of the property in the territory to be annexed or withdrawn, or by a resolution adopted by the Boundary Commission. In addition to these methods which apply to both cities and districts and are found within the Boundary Commission Law, three methods of initiating proposals for annexation of territory to cities, but not districts, are provided elsewhere in ORS. These are "health hazard, ${ }^{5}$ "island," 6 and most importantly "triple majority." 7 annexations. The Comission is allowed 90 days in which to act on a minor boundary change proposal and failure to act within the period is considered approval of the proposal. The Portland Commission has never allowed the time limit to lapse on any type of proposal before making a decision.

The Boundary Commission Law requires the Commission to prepare a study and conduct public hearings on each proposed boundary change, major and minor. The Commission may modify proposals by adding or subtracting territory. If the Commission disapproves a proposal of any kind, the proceedings terminate. If the Commission approves a major boundary change other than the merger or consolidation of special districts, the proceedings revert to the principal act which, in most cases, will require an election in the affected cities or districts to 
put the proposal into effect. Commission approval of the merger or consolidation of special districts is final and effective as it requires no election and is not subject to remonstrance. If the Commission approves a minor boundary change other than those initiated under "triple majority," "island" or "health hazard" provisions, the proposal takes effect after 45 days unless a remonstrance is filed. A remonstrance may be initiated by resolution of the governing body of the affected city or district or by petition signed by at least 20 per cent of the eligible voters in the affected territory. If no remonstrance election is required, the proposal takes effect after 45 days with no further action. Annexations initiated under "triple majority," "island" or "health hazard" provisions are final and effective upon approval as they are not subject to remonstrance. All decisions of the commissions are subject to court review as stipulated in ORS 199.461(3):

"... Any person interested in a boundary change may, within 30 days after the date of a final order, appeal the order for review under ORS 34.010 to 34.100." ORS 34.010 to 34.100 is the Administrative Procedures Act and provides for appeal directly to the Stato Covrt of Appeals. The original Boundary Commission Law, which applied until recently, provided for appeal to State Circuit Court.

From its inception on July 1, 1969 until June 30, 1977, the Portland Boundary Commission acted upon a total of 1,212 proposals. of this total, 1,077 were major and minor boundary changes and 135 were proposals dealing with the formation, extension and granting of service boundaries to sewer and water systems. Of the total 1,077 major and minor boundary changes, 1,033 were minor, 44 major. The 44 major 
boundary change proposals consists of thirteen different types of proposals. Of these thirteen types, the combination of formation and merger of county service districts made up slightly more than half. Proposals to merge water districts constituted about 13 per cent and no other type made up more than 10 per cent of the total. The 1,033 minor boundary change proposals consisted of twelve types. Of these, annexation to cities constituted approximately half, annexation to water districts about 20 per cent and annexation to county service districts about 10 per cent. No other type made up over 10 per cent of the total. Tables IV, V, and VI provide more detailed information on the Commission's case load.

TABLE IV

SUMMARY OF BOUNDARY CHANGE PROPOSALS COMPLETED

\begin{tabular}{l|c|c|c|c}
\hline $\begin{array}{l}\text { Type of } \\
\text { Proposal }\end{array}$ & $\begin{array}{c}\text { Number of } \\
\text { Proposals }\end{array}$ & $\begin{array}{c}\text { Number } \\
\text { Approved }\end{array}$ & $\begin{array}{c}\text { Number } \\
\text { Denied }\end{array}$ & Biennium \\
\hline Major & 15 & 12 & 3 & $1969-1971$ \\
Boundary & 15 & 11 & 4 & $1971-1973$ \\
Changes & 8 & 5 & 2 & $1973-1975$ \\
& 6 & 34 & 10 & $1969-1977$ \\
\hline Subtotal & 44 & 244 & 17 & $1969-1971$ \\
\hline Minor & 261 & 268 & 30 & $1971-1973$ \\
Boundary & 298 & 232 & 31 & $1973-1975$ \\
Changes & 211 & 923 & 110 & $1969-1977$ \\
\hline Subtotal & 1033 & 957 & 120 & $1969-1977$ \\
\hline Total & 1077 & & & \\
\hline
\end{tabular}


TABLE V

PROPOSALS BY TYPE, BIENNIUM AND ACTION

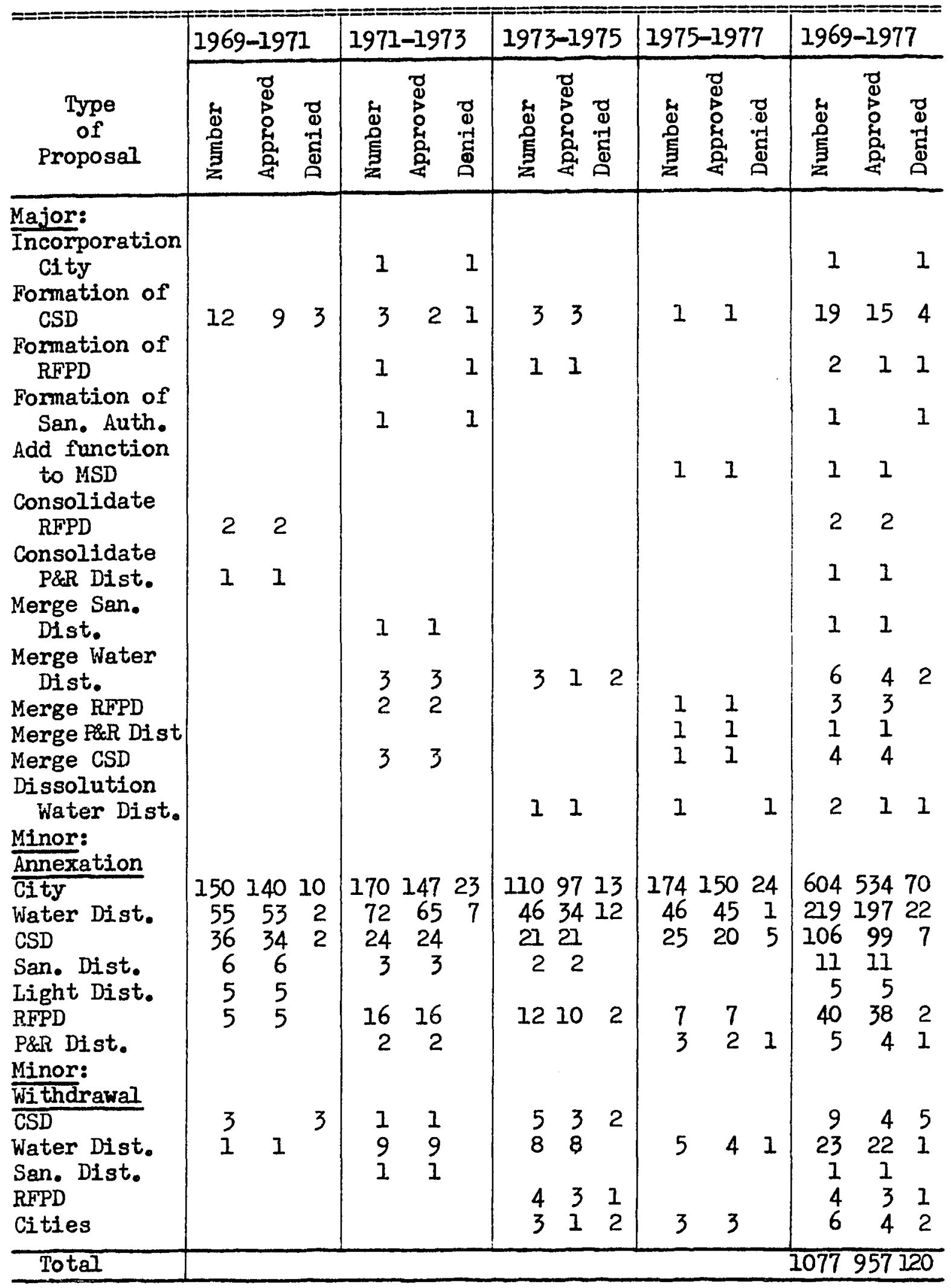


TABLE VI

SEWER AND WATER PROPOSALS BY TYPE, BIENNIUM AND ACTION

\begin{tabular}{|c|c|c|c|c|c|c|c|c|c|}
\hline Biennium & \multicolumn{3}{|c|}{$1973-1975$} & \multicolumn{3}{|c|}{$1975-1977$} & \multicolumn{3}{|c|}{$1973-1977$} \\
\hline $\begin{array}{l}\text { Entity Involved } \\
\text { and } \\
\text { Type of Action }\end{array}$ & 芯 & 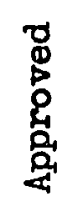 & 总 & 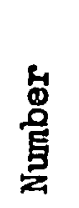 & 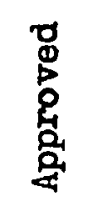 & 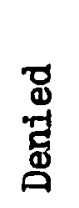 & $\frac{\text { S }}{\mathrm{D}}$ & 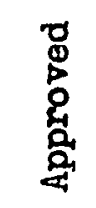 & 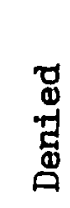 \\
\hline $\begin{array}{l}\text { Private Water Systems } \\
\text { Extensions } \\
\text { Formations } \\
\text { Service Boundary }\end{array}$ & 11 & 9 & 2 & $\begin{array}{l}6 \\
11 \\
14\end{array}$ & $\begin{array}{r}6 \\
5 \\
12\end{array}$ & $\begin{array}{l}6 \\
2\end{array}$ & $\begin{array}{r}6 \\
22 \\
14\end{array}$ & $\begin{array}{r}6 \\
14 \\
12\end{array}$ & $\begin{array}{l}8 \\
2\end{array}$ \\
\hline Subtotal & 11 & 9 & 2 & 31 & 23 & 8 & 42 & 32 & 10 \\
\hline $\begin{array}{l}\text { Public Water Extensions } \\
\text { Cities } \\
\text { Water Districts }\end{array}$ & $\begin{array}{l}5 \\
3\end{array}$ & $\begin{array}{l}5 \\
2\end{array}$ & 1 & $\begin{aligned} 35 \\
6\end{aligned}$ & $\begin{array}{r}32 \\
6\end{array}$ & 3 & $\begin{array}{r}40 \\
9\end{array}$ & $\begin{array}{r}37 \\
8\end{array}$ & $\begin{array}{l}3 \\
1\end{array}$ \\
\hline Subtotal & 8 & 7 & 1 & 41 & 38 & 3 & 49 & 45 & 4 \\
\hline$\frac{\text { Private Sewer Systems }}{\text { Extensions }}$ & 1 & 1 & & 2 & 2 & & 3 & 3 & \\
\hline $\begin{array}{l}\text { Public Sewer Extensions } \\
\text { Cities } \\
\text { County Service District } \\
\text { Sewer }\end{array}$ & 17 & 16 & 1 & $\begin{array}{r}20 \\
4\end{array}$ & $\begin{array}{r}10 \\
4\end{array}$ & 2 & $\begin{array}{r}38 \\
4\end{array}$ & $\begin{array}{r}34 \\
4\end{array}$ & 3 \\
\hline Subtotal & 17 & 16 & $I$ & 24 & 22 & 2 & 41 & 38 & 3 \\
\hline Total & 37 & 33 & 4 & 98 & 85 & 13 & 135 & 118 & 17 \\
\hline
\end{tabular}

The Boundary Commission has acted to approve as subaitted or modified, nearly 90 per cent of all proposals brought before it. It is important to recognize that many proposals are approved "as modified" which would not have been approved in their original form. Failure to take this into account would tend to undervalue the Comnission's effect upon the boundary change process. Approval rates for major and minor boundary changes and sewer and water proposals are about the same while 
approval rates for major boundary changes are somewhat lower than minor changes, 77 and 89 per cent respectively.

In looking at the proposals over time, one is struck by the constancy of the numbers of proposals submitted to the Commission. While the number of major boundary change proposals coming before the Commission has declined stince 1969 by more than 50 per cent, the combined total of major and minor proposals has not changed significantly over the four bienniums the Comission has been in existence. However, the addition of sewer and water responsibilities in 1973 has added to the total work load of the Conmission. The number of such proposals increased more than two and one-half times from the first biennium in which the Law assigned such responstbilities to the Commission, to the second, and they now total about one-third of the total number of proposals acted upon each year. The distribution of types of proposals within the minor boundary change category, alluded to earlier, has not changed significantly over the four bienniums. The decline in the number of major boundary change proposals over time is exaggerated by the fact that the large number of proposals to form county service districts in the 1969-1971 biennium skewed the figures. Fully half of the county service districts formed in the 1969-1971 biennium were formed for the purpose of absorbing, through annexation, a multiplicity of highway lighting districts and this action would not be repetitive or continuous.

In summary, the number and distribution of the proposals acted upon by the Commission has held nearly constant under the provisions of the 1969 law. However, the addition of sewer and water 
responsibilities in 1973 added to the number and by the 1975-1977 biennium, totally accounted for a 33 per cent increase in the total number of proposals over the total for the 1969-1971 biennium. Measured simply on the basis of numbers of proposals the agenda of the Commission is dominated by sewer and water proposals considered as a class, and annexations to cities, which constitute respectively 24 and 48 per cent of the total.

The numbers of proposals coming before the Commission is but one index of the work load. As important a factor in increasing the Commission's work load, has been the increasing length and complexity of the study and analysis which the staff performs on each proposal as required by the law. $^{8}$ The increasing length and complexity of the staff study is matched by increasing allocations of time for public hearings on proposals. One of the effects of this has been that the Commission tends increasingly to carry over hearings from one public hearing to the next. During the interim, the staff may be instructed to perform additional study or the petitioners may use the interval to modify the proposal to meet Commission objections raised in the first hearing. While the studies vary in length and complexity among proposals, all proposals today consume greater resources than the same proposal would have in the early period of the Commission. The number of factors which are assessed for applicability to each proposal, and if determined to be applicable are applied, has grown significantly over the eight years of Commission operation. The extent of the analysis is a function of two factors. One, the greater the affect of the proposal, the more extensive the analysis. Second, the more controversial the proposal, 
the more extensive the analysis. Thus, to some extent, the length and depth of the staff study is determined by the information requirements inherent to the proposal and to some extent, is a response to the perceived need to ground the action solidly should there be a legal challenge to the Commission action. The following summary of "staff study factors" is taken from the instruction form the Commission supplies to persons interested in filing a proposal for annexation to a city under the triple majority method:

Reason for action.

Land use and conformance to applicable planning and zoning: ICDC goals. CRAG Framework PIan Element. County Comprehensive Plan. City Comprehengive Plan. Demography:

Population. Population density. Growth potential.

Proximity to populated areas-define populated area in terms of number of homes, businesses, etc. Relation of growth and density to CRAG and county plans. Adequacy of Public Facilities and Services:

Water.

Sewer.

Fire protection.

Police protection. 
Parks and recreation.

Streets and traffic regulation.

Street 11ghts.

Storm sewers.

Library.

Schools.

Transportation.

Metropolitan Service District.

Vector control.

Private utilities-electricity, garbage, telephone, natural gas

Public Economic Considerations:

Financial integrity of units of government costs now versus costs later.

Debt structure obligations.

Other Govermment Factors:

Logic of the particular expansion-should it be enlarged or contracted?

Contiguity.

Impact on other units.

Relationship of property to government codes.

The Boundary Commission staff notifies and considers response from, all affected governmental units, including state and federal agencies which may have an interest in this proposal (State Health Division, U.S. Forest Service, Department of Environmental Quality, etc.), county departments (Building and Sanitation, Flanning, etc.), and cities and districts in the vicinity of proposed change.

All known neighborhood groups, service and other organizations, and individual citizens known to be interested in a proposal are also notified and their responses considered as a part of the staff review. 
Given this exhaustive list of potential study criteria, it is understandable that in those cases where most of them are applicable, the staff report may run twenty pages, single-spaced with small margins. These reports are supplied to the commissioners about five days before the public hearing and are made available to interested parties at the hearing itself. It is not unusual for a cormissioner to receive a package of staff reports and related materials one and one-half inches thick a week before the public hearing at which they will be reviewed. An excellent example of this increase in size and complexity are two actual staff reports on consent annexation proposals No. 98 and No. No. 1198. These were received by the Commission on January 26, 1970 and February 3, 1978 respectively and concern exactly the same parcel of land submitted for annexation to the City of Banks by consent petition. 9

Public hearings on each proposal are required by the Boundary Commission Lat. ${ }^{10}$ Hearings are held about every lour weeks and a tentative schedule is prepared for each Commission year, July I to June 30. After following a policy of holding hearings in different locations in the first two years, the Commission has for the past several years held its hearings in the centrally located Multnomah County Courthouse. In its first years of operation, the Commission would first hold a public hearing on all the proposals on the agenda, end the public hearing and then reconvene in a non-hearing meeting and make decisions on the proposals. For the past few years, the Cormission has followed a format of holding a hearing and deciding each proposal seriatim. For several years, the Commission has held a 
one-hour discussion meeting imnediately before the public hearing at which time the staff briefs the Commission on each proposal and discusses its recomendtions. This meeting is open to the public as required under the State's Open Meeting Law.*

All proceedings of the Commission are governed by Roberts' Rules of Order, Revised, except as provided otherwlse under the Commission's official Rules and Procedures. A majority of the members of the Commission constitute a quorum and a majority of a quorum may act for the commission except that as provided by statute, approval of an absolute majority of the members of the Commission is required to adopt a final order on a boundary change. In the consideration of each proposal on the agenda, the proponents speak first, followed by the opponents, with rebuttal allowed. Only Comnission members and staff may ask questions of the persons giving testimony. All questions concerning the hearing and testimony given must be made through the preslding officer. Any interested person may appear and will be given a reasonable opportunity to be heard, but the presiding officer may limit the time available for discussion on any proposal. Any person may appear in his behalf or by subnitting a written statement in advance of the day of the hearing. An appearance may be made on behalf of any person by his or her attomey or other authorized representative. Generally, anyone who wants to present testimony may, and the Commission is very generous in allocating time for testimony. Meetings of the

*The provisions of ORS 192.610 to 192.710, the "Open Meeting Law," apply to all meetings of the Commission. These provisions include proper public notice of meetings, written minutes of all meetings and executive sessions for certain purposes. 
Commission begin at 7:00 p.m. and often conclude as late as 1:00 a.m. Lay persons who are unfamiliar with such public proceedings and manifest their discomfort in halting speech and a somewhat confusing logic seem to suffer no disadvantage before the Conmission. It would seem that one needs neither to be or employ a "Philadelphia lawyer" to take one's case to the Commission.

To a lay person, the Commission proceedings appear as informal, tolerant, and accessible. This perception is widely shared by the Comission members and they rociferously and adamantly defend this manner of proceeding as an essential feature of the Commission's operation. 


\section{FOOTNOTES}

1. ORS 199.415(12).

2. ORS $199.415(13)$.

3. ORS 198.705 to 198.555 .

4. ORS 199.410 to 199.512 .

5. ORS 222.850。

6. ORS 222.750。

7. ORS 222.170.

8. ORS 199.461(8).

9. Appendix, pp. 231-238.

10. ORS 199.461(b). 
CHAPTER VII

PATTERNS AND POLICIES

Webster defines policy as: "A definite course or method of action selected from among alternatives and in light of given conditions to guide and determine present and future decisions." $I$ The Boundary Commission is itself an expression of policy on the part of the State of Oregon, and the Commission, in turn, has been a promulgator of policy. There are at least three levels of policy which condition the operations of the Commission.

At the highest level are a set of seven State policies which serve to define the purpose and guide the actions of the Boundary Commission. These State policies represent the result of choices on the part of the State legislature which meet the requirements of Webster's definition of policy. They represent a course of action selected from among alternatives in light of given conditions to guide present and future decisions, including the present and future actions of the Boundary Commission. Five of these policy goals are found thin the Policy and Purposes Section of the Boundary Commission Law:

1. To guide the creation and growth of cities and special districts to prevent illogical extensions of local government boundaries; 2

2. To assure adequate quantity and quality of public services; ${ }^{3}$ 
3. To assure the financial integrity of each unit of local government; 4

4. To prevent the fragmentation of public services and local government; 5

5. To contain the intergovermmental affects of local government programs and growth. 6

Another of the policy goals is imposed by the Land Conservation and Development Commission Law:

6. To enforce and implement LCDC goals and guidelines.*

The final State policy goal was contained in the budget footnote attached to the 1971 budget:

7. To eliminate special districts. ${ }^{7}$

The next level of policy consists of the results of choices made by the State with respect to implementation. The State implementation policy was to create boundary commissions with jurisdiction over specified boundary changes and to prescribe a process to be followed in reviewing such boundary changes and a set of general substantive criteria to examine in the review process. ${ }^{8}$ The criteria provided by the State include:

1. Economic trends and projections;

2. Sociological trends and projections;

3. Demographic trends and projections;

*ORS 197.180. "(1) State agencies shall carry out their planning duties, powers and responsibilities and take actions that are authorized by law with respect to programs affecting land use in accordance with statewide planning goals approved pursuant to ORS 197.005 to 197.430 and 469.350." ORS 197.005 to 197.430 is entitled, "Comprehengive Planning Coordination." 
4. Past and prospective use of land directly or indirectly affected. ${ }^{9}$

In addition to these explicit criteria, one should add a fifth:

5. Intergovernmentel impact;

which must be included because the State policy goal of incorporating and capturing intergovermental effects within the decision-making process implies that such affects would have to be one of the criteria for analysis in the boundary review process. This goal is much more procedural in nature than the other six which are basically substantive.

These two levels of policy provide the Boundary Commission with a set of given conditions in light of which it would select courses of action from among alternatives to guide future decisions. The goals and criteria supplied by the State are very general, and it was necessary that the Comnission develop means by which it could make operational the State criteria to meet the State goals. In doing so, the Commission was creating the third level of pollcy.

The Portland Boundary Commission has formally adopted policies on four occasions: November 19, 1969; March 11, 1970; May 20, 1970; May 1, 1974, and currently has a set of policy positions under consideration for formal adoption. These formally adopted and promulgated policies are, however, not very inclusive and fail to reflect a large number of policies which the Commission has selected as a course of action. This paucity of formally adopted and promulgated policies has been a source of concern both within and without the Commission and will be dealt with specifically elsewhere in this work. Suffice it to say at this point that the lack of formal policies does not reflect a 
similar lack of effective or operative policies.

The operative policies which guide and determine Commission decisions can themselves be grouped into three basic types within each of which there is a common thread. One set of policies relates to governmental structure, meaning in this case the pattern of local government organization not the internal makeup of local governments, and taken together constitutes a structural hierarchy in which the Commission generally prefers the following order for the provision of urban services: cities, regional multiple-service districts, county service districts, and lastly special districts. The Cormission's reasoning is that general purpose units of government provide an optimal structure for achieving the set of goals set by the State. In addition to those policies constituting the structural hierarchy are policies which indicate a Commission preference for containing the growth of government both numerically and territorially. While the commission seldom has before it a proposal which presents a clear choice between utilizing a more general or a less general unit of government to provide services, when it has, it has acted decisively to utilize the more general. Proposal No. 335 presented a clear choice between utilizing the City of Portland or a county service district to provide sewer service in the area. Residents preferred the district but the Commission approved annexation to the City of Portland under the "health hazard" annexation procedure which makes Comnission decisions final and not subject to remonstrance. 10

A second set of policies relates to land use planning and when taken together constitutes a planning hierarchy. The Land Conservation 
and Development Commission (ICDC) law places the LCDC Goals and Guidelines at the top of the hierarchy, and the Boundary Commisstion has arranged the descending order: Columbia Region Association of Governments (CRAG), county and city comprehensive land use plans and urban growth boundaries where they exist. Some cities within the Commission's jurisdiction have developed urban growth boundaries and CRAG is in the process of so doing. The Commission examines each proposal for conformance to each applicable level of plan. When the projected land use effect of the proposal conflicts with existing plans at any level, the Conmission usually dentes the proposal. When the plans themselves are in conflict in the territory in question, the Commission usually withholds its decision, or denies without prejudice for resubmittal, until the units of government are able to resolve the planning conflicts. The Commission is very emphatic that it simply applies and enforces land use planning generated by units of govemment which have a legal power and responsibility to do so and that it does not seek to substitute its planning judgment for theirs. The Commission admits to a structural planning responsibility as evidenced in the structural hierarchy, in which the Commission makes substantive choices. In the land use arena, the Commission adopts the role of a procedural implementor of the substantive choices made by planning bodies. ${ }^{11}$

A third set of policies relates to the procedures of the Cormission as distinguished from the rules of procedure which the law requires the Cormission to adopt and amend formally. ${ }^{12}$ Four of these policies are significant in terms of their affect upon the commission's decision-making process. In order to implement the State goal of 
assuring an adequate quantity and quality of public services, the Commission staff in its reports analyzes, where applicable, the adequacy of a large number of public services. These services include: water, sewer, fire protection, police protection, parks and recreation, streets and traffic regulation, street lights, storm sewers, library, schools, transportation, vector control, private utilities. ${ }^{13}$ In evaluating the public services, the Commisston follows a policy of requiring water and sewer services to be adequate absolutely, requiring police and fire service to be at least as good under the new provider as exdisted before the boundary change, and considering the remaining services as a package wherein the strength of one service may offset the weakness of another. By following this pattern, the Commission has, in effect, a public service hierarchy.

Another policy followed by the Comnission and one indicated in the discussion of the Gresham annexation case, is to avold making substantive decisions on issues where there are contending governments and to encourage the conflicting parties to negotiate an acceptable solution. This applies to both conflicts arising from land use and those dealing with public service provision. In the Gresham annexation case, the Cormission used its "good offices" as an intermediary to bring about solutions to land use conflicts among CRAG, Mul tnomah County, and the City of Gresham. In doing so, it applied existing land use plans to the projected land-use effects of the proposals, found conflict, and acted to eliminate the conflict without usurping the land use planning respansibilities of the units of govermment involved. Also in that case, the Cormission in following its public 
services hierarchy, found that the quality of fire protection in the area in question would decline if the proposals were approved as submitted. The "Staff Report" indicated that the existing quantity and quality of fire protection provided by RFPD No. 10 was better than that projected by the City of Gresham. The Commission withheld action on the proposals until the fire protection component was brought up to promexisting levels. The Commission did not attempt to impose its judgment on the technical aspects of providing fire service to the area in question but again offered its good offices as an intermediary to facilitate a solution which would meet the State policy goal.

A third operations policy followed by the Commission is a policy of not pursuing unpopular actions. This has two basic dimensions. The first relates to Commission initiated proposals which arise from the structural planning functions of the Commission. While the Commission denies any responsibility for land use planning, it accepts a responsi= bility for planning the system and patterm of local governments in the region of its jurisdiction. In 1973 and 1974, the Portland Commission had received grant monies to finance a study of govermment reorganization in north Clackamas County. The study had as its purpose, unification of both fire and water districts in a manner
that would facilitate the ultimate unification of the north
Clackamas area into a complete general purpose unit of
govermment. 14

This attempt to use the study and initiation powers of the Commission to bring about structural reorganization proved to be extremely unpopular with the people in the study area, and the ill will generated convinced the Commission that, in spite of the wisdom of such 
a policy and the legal power to carry out the initial stages without a vote, it simply served no useful purpose to try to force such a policy on a recalcitrant population. 15 Since that time, the Commission has attempted to build an indigenous base of support for such schemes. The second dimension of this operations policy relates to remonstrances. Under the law, a remonstrance election can be called for certain types of approved minor boundary changes by a resolution of the governing body of the affected city or district or by a petition signed by at least 20 per cent of the qualified voters in the affected territory. The Commission has a policy of denying boundary change proposals which it determines will be successfully remonstrated and defeated in the ensuing election. The Commission usually operates on the assumption that any proposal which creates enough opposition to bring about a 20 per cent remonstrance petition will also be defeated in the election. 16 The statistics on remonstrances bear this out; there are very few remonstrances and they are nearly always successful. of the twenty-four remonstrance elections held in the period July 1, 1969 to June 30,1977 , only three have not been successful in overturning the Commission approval. That there are remonstrances does indicate that there aro cases in which the Commission approves unpopular remonstrable boundary changes because it considers such action necessary if the Commission is to responsibly implement its statutes.

Last, and perhaps least, the Commission appears to have a "hardship" pollcy with respect to "the little guy." On a number of occasions involving cases considered to have a minor impact, the Commission has approved boundary proposals it would not have otherwise 
because an individual, who himself or herself had a great deal at stake, would suffer great hardship if the boundary change were not approved. This appears to be particularly the case if the individual can pursuade the Commission that the predicament is due to callous behavior on the part of a unit of government.

Clearly, the thread that runs through these operating policies is caution and self-restraint. When combined with structure and land use oriented policies, the totality evinces tendencles toward acting only within a restrained jurisdiction clearly authorized by the law; a reluctance to impose its will upon others and a concomitant desire to achieve State goals through voluntary actions; a desire to operate on the basis of consensus rather than simple majorities or coalition building; and a sensitivity toward the desires of affected publics in excess of legal requirements. Progress made toward at least two of the State policy goals can be measured directly by examining the structure of local government in the Portland metropolitan aree over the period of boundary commission operation. Progress toward policy goal number four: the prevention of fragmentation; and policy goal number seven: the elimination of special districts; is demonstrated in Table VII. The elimination of special districts has been carried out by a reduction in the total number of those types of special districts under boundary commission jurisdiction from a total of 242 , when the commission came into existence, to a total of 100 as of the beginning of its fifth biennium. The effect of this reduction is overstated because 100 of the total reduction of 142 has been due to reduction of highway lighting districts. Reductions in the number of the more important 
TABLE VII

UNITS OF GOVERNMENT WITHIN THE JURISDICTTON OF THE PORTLAND COMMISSION

\begin{tabular}{|c|c|c|c|c|c|c|c|c|c|}
\hline County & Columbia & Clackamas & Multnomah & Washington & \multicolumn{5}{|c|}{ Total } \\
\hline As of July 1: & 6971737577 & 6971737577 & 6971737577 & 6971737577 & 69 & 71 & 73 & 75 & 77 \\
\hline $\begin{array}{l}\text { Type of unit: } \\
\text { Fire Districts } \\
\text { Lighting Districts } \\
\text { Park Districts } \\
\text { Sanitary Districts } \\
\text { Water Districts } \\
\text { Vector control } \\
\text { Districts }\end{array}$ & $\begin{array}{lllll}6 & 6 & 6 & 6 & 6 \\
0 & 0 & 0 & 0 & 0 \\
1 & 1 & 1 & 1 & 1 \\
0 & 0 & 0 & 0 & 0 \\
0 & 0 & 0 & 0 & 0 \\
1 & 1 & 1 & 1 & 1\end{array}$ & $\begin{array}{rrrrr}19 & 19 & 19 & 20 & 20 \\
21 & 20 & 19 & 6 & 6 \\
1 & 1 & 1 & 1 & 1 \\
4 & 4 & 3 & 3 & 2 \\
22 & 22 & 22 & 21 & 21 \\
1 & 1 & 1 & 1 & 1\end{array}$ & $\begin{array}{rrrrr}11 & 10 & 9 & 9 & 8 \\
62 & 4 & 1 & 0 & 0 \\
0 & 0 & 0 & 0 & 0 \\
0 & 0 & 0 & 0 & 0 \\
20 & 20 & 20 & 17 & 17 \\
0 & 0 & 0 & 0 & 0\end{array}$ & 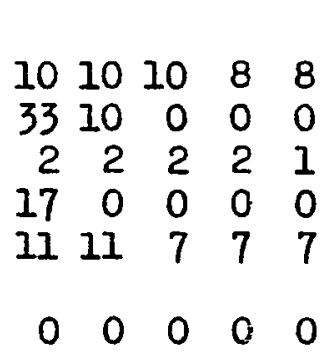 & $\begin{array}{r}46 \\
116 \\
4 \\
21 \\
53 \\
2\end{array}$ & $\begin{array}{r}45 \\
34 \\
4 \\
4 \\
53\end{array}$ & $\begin{array}{r}42 \\
20 \\
4 \\
3 \\
49\end{array}$ & $\begin{array}{r}43 \\
6 \\
4 \\
3 \\
45 \\
2\end{array}$ & $\begin{array}{r}42 \\
6 \\
3 \\
2 \\
45 \\
2\end{array}$ \\
\hline $\begin{array}{l}\text { Total Special } \\
\text { Districts }\end{array}$ & $\begin{array}{lllll}8 & 8 & 8 & 8 & 8\end{array}$ & 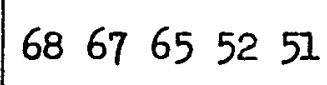 & 9334302625 & 7333191716 & 242 & 142 & 120 & 03 & 100 \\
\hline $\begin{array}{l}\text { County Service } \\
\text { Districts } \\
\text { Cities }\end{array}$ & $\begin{array}{lllll}C & 1 & 1 & 1 & 1 \\
7 & 7 & 7 & 7 & 7\end{array}$ & $\begin{array}{rrrrr}1 & 6 & 7 & 7 & 6 \\
12 & 14 & 14 & 14 & 14\end{array}$ & $\begin{array}{rrrrr}21 & 22 & 8 & 8 & 8 \\
6 & 6 & 6 & 6 & 6\end{array}$ & $\begin{array}{rrrrr}4 & 6 & 2 & 3 & 3 \\
12 & 12 & 12 & 12 & 12\end{array}$ & $\begin{array}{l}26 \\
37\end{array}$ & $\begin{array}{l}35 \\
39\end{array}$ & $\begin{array}{l}18 \\
39\end{array}$ & $\begin{array}{l}19 \\
39\end{array}$ & $\begin{array}{l}18 \\
39\end{array}$ \\
\hline Total All Units & $15 \quad 16 \quad 16 \quad 16 \quad 16$ & 8187867371 & $\begin{array}{lllll}120 & 62 & 44 & 40 & 39\end{array}$ & $\begin{array}{lllll}89 & 51 & 33 & 32 & 31\end{array}$ & 305 & $\angle 10$ & 177 & 101 & 157 \\
\hline
\end{tabular}


types of special districts have been far less dramatic. Fire districts have been reduced from 46 to 42 and water districts from 53 to 45 . Also exaggerating the reduction in numbers was the reduction from 17 to 0 of sanitary districts in Washington County. This was brought about by the creation of the Unified Sewerage Agency of Washington County which absorbed the seventeen separate districts instantly. The proceedings to form this agency began before the Boundary Commission Law and the Commission was not a participant in the process. This is also the case with cities, the only type of local government to show an absolute increase in numbers during the Commission's existence. Both of the cities created during the 1969-1971 biennium, Johnson City and Rivergrove, were created as a result of proceedings initiated prior to the Boundary Commission Law. Perhaps the most important message to be drawn from Table VII is not the absolute reduction in numbers of governments, but the fact that there has been no increase in the numbers of governments despite a popuzation increase of about 12 per cent during the period in question. Population totel for the counties under Commission jurisdiction was 897,040 as of July 1,1969 and $1,001,500$ as of July $1,1977 .^{17}$

The veto power of the Commission has been very effective in preventing any increase in the numbers and resulting fragmentation of local government. While the more limited approval powers of the Commission has made it less effective in bringing about a reduction in the number of existing units through consolidation and merger and, to some extent, through annexation, the greater veto powers have certainly negated the problem of "defensive incorporations." There has 
been only one formal proposal to incorporate a city and the proposal was denied. How many would have been proposed if the Commission did not have policies tending against new incorporations cannot, of course, be determined. How many new incorporations would have taken place in the absence of the Commission is also impossible to determine. What can be known is that there have been no new cities incorporated, defensive or otherwise, under the Comission. Likewise, fragmentation, at least in terms of numbers of governments, has been halted and to a limited extent, absolutely reduced. 
FOOTNOTES

1. Webster's Seventh New Collegiate Dictionary (Springfleld, Mass: G\&C Merriam Company, 1972), p. 656.

2. ORS $199.410(2)$.

3. Ibid.

4. Ibid.

5. ORS $199.410(a)$.

6. ORS 199.410(b). ORS 199.410(c).

7. Oregon Legislature. Joint Committee on Ways and Means. 1971 Oregon Legislature, Regular Session, "Minutes," Salem, Oregon State Archives.

8. ORS 199.461.

9. ORS 299.462.

10. Portland Boundary Commission, "Staff Report" on proposal No. 335, October 27, 1971, Portland, Portland Boundary Comission files.

11. Don Carlson, Letter from Don Carlson to Glen Otto, Chairman, House Cormittee on Local Government and Urban Affairs, March 18, 1975, Portland, Portland Boundary Commission files.

12. ORS 199.452。

13. Portland Boundary Commission, "Instruction for Filing Minor Boundary Change Proposals," Portland, Portland Boundary Commission files.

14. Daniel, Mann, Johnson and Mendenhall, Implications of Government Unification North Clackamas County, Oregon, (Portland: Daniel, Mann, Johnson and Mendenhall, 1973), p. 11.

15. Ken Martin, Private interview, Portland, April 26, 1978.

16. Ibid.

17. Center for Population Research and Census, Population Estimates, Oregon Counties and Incorporated Cities, (Portland: Center for Population Research and Census, Portiand State University). 
CHAPTER VIII

THE COMMISSION IN STATE POLITICS

The three boundary commissions faced serious threats to their institutional existence during the 1977 Oregon Legislature. In addition, the Portland Boundary Commission faced threats to its funding and to its territorial jurisdiction. These separate fronts were, however, manifestations of a set of political liabilities which accrue to the commissions because of their institutional structure and functions.

As discussed above, the degree of support for boundary commissions within the State legislature had been declining, especially when measured by votes on boundary commission appropriation bills over time. In the 1977 Legislature, this development reached a stage where the funding for the commissions, and thus the continued existence of the commissions as institutions, was placed in serious doubt. The commissions" difficulties began during the review of the proposed budget in the Senate Ways and Means Committee. In examining the budget, a majority of the members, including Chairman Jack Ripper, expressed serious doubt about the necessity of maintaining the boundary commissions. ${ }^{1}$ Giving rise to these doubts was a belief on their part that the boundary comissions were essentially land use planning bodies and that the development of the Land Conservation and Development Commission ( $\mathrm{CCDC}$ ) had made the boundary commissions redundant. As a 
result, the Legislative FIscal Officer with responsibility for the boundary cormissions, Dan Simmons, wrote the following budget note which the Comnittee attached to the appropriation bill by amendment when it went to the Senate floor for action. ${ }^{2}$ Similar language was attached to the appropriation bills of the Salem and Eugene Commissicns:

Section 3. There is appropriated to the Emergency Board, for release during the fiscal year beginning July 1 , 1978, out of the General Fund, the sum of $\$ 89,787$. Such sum may be released by the Emergency Board to the Portland Metropolitan Area Local Government Boundary Commission only if the legislative interim comnittee assigned responsibility for the study and review of the duties, functions and powers of local government boundary commissions, $_{\text {g }}$ transmits to the Emergency Board a written finding that there is a need for the continued operation and state funding of local government boundary commissions.*

The result of this would have been to fund the Commission for one year, pending review, and to appropriate funds to the Emergency Board to be used to fund the Commission for a second year if the interim committee so recommended. The bill passed narrowly, 16 to 13, with this provision but there was suibstantial objection to this process among both supporters and opponents of the boundary commissions. Senator Frank Roberts, an outspoken supporter of the commissions, voted reluctantly for the bill and explained his vote in the Senate Journal:

I voted aye on this bill because at present this is the only way to continue the good work of this boundary commission. I am sure the report of the interim committee on the work of boundary commissions will give further evidence of their value. However, I am reluctant to vote for the bill in this form because it might result in our having to call a spectal session of the legislature to make a decision which should be made in regular session. 3

*The Emergency Board is created by Article III, Section 3, of the Oregon Constitution and is titled: Joint Legislative Comittee to Allocate Fmergency Fund Appropriations and to Authorize Expenditures Beyond Budgetary Limits. Its term runs from the adjoumment of one regular session to the organization of the next regular session. 
Senator Wingard stated:

I voted aye on these measures to support the concept of boundary comnissions. I do, however, have some deep reservations about the method in these bills that would allow the Emergency Board to make the decision as to whether funding should exist in the second year of the biennium for boundary commissions. 4

Senator Carson, who voted against the bill, and was opposed to continuing the commissions, stated: "And I also finally Mr. President, resent the apparently burgeoning concept of 'hostage' that is now a part of the Ways and Means bag. " 5

The boundary commissions appropriations faced four groups of Senators on the floor. One group was made up of those Senators who favored the continued institutional existence of the commissions and wanted full two-year funding. Second were those who had serious doubts about the necessity of continuing the commissions, based on a perception that the boundary commissions were essentially land use planning bodies and might well be absorbed by the LCDC. These Senators felt that the only way to obtain a remevaluation of the commissions by a legislative interim committee was to force the issue through a split funding scheme. Third, those who were against continuing the commissions, based primarily upon a basic philosophical opposition to land use and growth control which they considered to be excessive and which they applied to the commissions because they too perceived them as land use planning agencies. Last, those who supported the commissions but whose support for the cormissions was outweighed by a desire to attack what they considered to be the usurptive actions of the Ways and Means Comittee and the Emergency Board. In the actual vote, those Senators who wanted the split appropriation were joined by: those who wanted the full 
two-year appropriation; and some of those who objected to the split appropriation but placed support for the commissions above their antipathy toward Ways and Keans and the Imergency Board, to form a majority coalition of sixteen. The losing Senate coalition of thirtieen consisted of: those who opposed the combissions as land use planning bodies; those who supported land use planning, perceived the commissions as planning bodites and therefore considered them redundant in the presence of ICDC; and those who had no opinion on the merits of the commissions but were opposed to passing a bill giving the Ways and Means Committee and the Emergency Board what they considered to be excessive power.

On February 11, 1977, the appropriation bill containing the split funding budget note, was referred to the House Committee on Ways and Means where it received a do-pass recommendation and went to the House floor for a vote on March 17. On the 17th, the bill fell victim to a motion to re-refer and was returned to the House Comittee on Ways and Means where it was to languish for three and one-half months until a voting tradeoff with another bill garnered sufficient support on the House floor to pass the appropriation. The Portland Boundary Commission appropriation had the votes in House Ways and Means Committee but not on the floor.

Early in the session, Representative Magruder and a few others had introduced H.B. 3030. This bill had as its purpose the removal of Columbia county from the territorial jurisdiction of the Portland Boundary Commission. Representative Magruder was elected from House District One which includes Columbia County and considered himself a 
conservative Democrat. ${ }^{6}$ He was the leader of a small group of conservative Democrats in the House, known as the "Hornets" which used its tactical position to play coalition-politics, going as far as forcing a leadership change midway in the session. His bill, H.B. 3030 , was referred to the House Committee on Intergovernmental Affairs where it was tabled on May 10, 1977. The Committee action was based upon the position that the continuation of the boundary commissions ought to be squarely faced and attempts to erode their jurisdiction discouraged. 7 When the bill was tabled, the Magruder forces adopted a less direct strategy of achieving the same ends. The first step was to build a coalition on the House floor that would have sufficient strength to re-refer the Portland Boundary Commission's appropriation bill to the House Committee on Ways and Means and to prevent passage until such time as a bill was passed which would remove Columbia County from the Portland Commission's jurisdiction. It must be emphasized that this coalition was built around the action of preventing funding until Columbia County was removed, not on the institutional demise of the Peztland. Commission or the boundary commissions generally. The House broke down somewhat differently than the Senate into three groups. One group consisted of a small number of representatives who supported the idea of land use and growth control and the comissions generally, the Portland Commission specifically, and favored full funding for the biennium but were willing to accept the split funding because they felt that it was necessary to Senate passage. Another group consisted of the "Hornets" who, under the leadership of Representative Magruder, opposed land use and growth control and the commissions generally, but whose 
primary goal was to remove Columbia County from the Portland Commission's jurisdiction. Magruder and the "Hornets" were willing to allow full funding for the biennium for all three commissions and to withhold support from the transfer of the commissions to ICDC if the commissions' supporters would support removal of Columbie County. A third group consisted of all of the remaining members of the House whose commonality was based on a profound ignorance of, and indifference toward, the commissions generally and the Portland Commission particularly.

Second, a bill to remove Columbia County was introduced in the Senate by the Joint Committee on Ways and Means, S.B. 1113, on June 7, 1977. The bill was referred to Senate Ways and Means where it was amended to include language which, in addition to removing Columbia County from the jurisdiction of the Portland Commission, abolished the three commissions and transferred their entire operation to the LCDC. When it came to the floor on June 27, it was re-referred to Ways and Means because of the four groups in the Senate, only those philosophically opposed to land use and growth control voted to immediately eliminate the comissions as institutions. At this point, it was clear that there was not a majority in the Senate in favor of eliminating the comissions, nor was there a majority in favor of an unencumbered twoyear appropriation. Thus, both sides were convinced that the split funding scheme was the best they could achieve. After amending out this amendment, the bill returned to the floor on July 1,1977 where it was passed by a large margin-25 to 5.

Upon receipt by the House on the same day, the bill was referred 
to House Ways and Means. The appropriation bill, S.B. 5544, was amended in House Ways and Means to remove the split appropriation scheme because the State Attorney General had issued an opinion that the split funding plan violated the Oregon Constitution.* It passed the House on July 2, and went to the Senate where it was scheduled for repassage with House amendments on Jury 4, 1977, the same day S.B. 1113 was roted on in the House. Not surprisingly, both were passed: S.B. 1113 passed the House 39 to 20 and S.B. 5544 repassed the Senate 17 to 13. During the period between the re-referral of S.B. 5544 to House Ways and Means on March 17, 1977 and its release on July 1, 1977, the Commission, the Commission's staff, and its legislative supporters worked hard to build support for the appropriation; to keep Columbia County within its jurisdiction; and to prevent mandatory transfer to ICDC. None of these parties objected to the proposal for interim committee review of the Commission's functions or operations, but they did oppose the split funding. In its defense at the legislature, the Commission made all of the arguments that it had made in earlier sessions, especially its claims of having substantially reduced the number of governments in the Portland metropolitan area. This had always been the leading argument of the boundary commission proponents.

*James A. Redden, Attorney General, Opinion No. 7448 , p. 826. "It is up to the legislature as a whole to decide, on the advice of its comnittees, what programs shall be initiated, funded, or terminated. These are policy decisions which cannot (consistent with Article IV, Sections $I$ and 25) be delesated to only some members of the legislature, except as specifically authorized by Article III, Section 3. The legislative proposals under consideration allow the decision to be made twice removed from the only body-the entire legislsture-which has authority to make it." Pages 837-838. 
Beginning with the 1973 session, the Comnission began to argue that its actions in enforcing and implementing land use plans, in addition to its other functions, justified their continued existence. This line of reasoning came back to haunt them in the 1977 session where many of the legislators, convinced that the commissions were land use planning bodies, supported transferring the commissions' functions and operations to LCDC. To counter these points, the Commission argued for its continued institutional existence on the basis that the boundary commissions differed from the LCDC in function, administration, and procedure:

First, there is a basic incongruity in the central focus of the two agencies. The Boundary Commission is concemed with the level of public services and the structure of entities which provide those services. The Land Conservation and Development Commission is concermed with land use. The Boundary Commission makes decisions on specific boundary changes and utilities extensions. ICDC sets statewide policy on land conservation and development for utilization by local governments in making dayto-day decisions on land use. The Boundary Commission uses land use (state, regional, local) as one of many criteria in making decisions on specific proposals. In about 65 per cent of the proposale which come in front of the Comisoion, land use is not an issue at all. For ICDC land use is the issue.

Second, the amendment as proposed would be unworkable in its present form. There are three boundary commissions operating in three separate areas. The Portland Cormission averages 15-20 proposals per month with public hearings usuelly lasting well past midnight. The Eugene area Commission averages 10 proposals per month and the Salem area Commission 10 proposals. Each Commission holds at least one public hearing per month plus study meetings and briefings. It is highly unlikely that even a full time Land Conservation and Development Commission could take on this diverse additional work load.

Third, there would appear to be some major acininistrative hurdles to be overcome with such an arrangement. It is difficult to believe that anything less than locally-based staffs could perform the research and investigation necessary for the various proposals. That staff which now makes recommendations directly to the Commission would be forced to clear everything from major recommendations to postage stamps through a Salem-based department which is attuned to an entirely different mission. The probability of reduced staff efficiency and quality in comparison 
with the present arrangement seems almost inevitable.

Fourth, there is in Oregon a traditional and currentiy quite a strong proclivity for retaining functions at as local a level of government as possible. Even though the current conmissions are appointed by the Governor and funded by the State, they are perceived as a local or regional operation by the individuals and units that utilize them. Once the commissions are converted to the ICDC, that local image will be gone.

Fifth, the conversion of the Boundary Commission to LCDC spells the loss of what many of us feel to be as a major feature of Boundary Commission operation: the informality, openness and nonintimidation which is a prevalent element in all of our proceedings. 8

In defending its jurisdiction over Columbia County, the Commission emphasized the increasing urbanization of the county, its adjacency to the Portland area, the record of Commission activity in the county, and the wisdom of applying boundary commission "medicine" in the county before it developed the kind of problems the commissions were created to help solve.

A significant portion of Columbia County-particularly the Scappoose, St. Helens, Columbia City area-is immediately adjacent to the Portland urban area. Improvements to U.S. highway 30 accent this adjacency, tying the area ever more closely with the rest of the urban area.

Columbia County is now experiencing the same kinds of growth and governmental boundary problems which the more immediately urben portions of the Portland metropolitan area were facing a number of years ago. Those problems eventually became so severe that a 'cure' for them was devised in the form of the boundary commission. The cure, as with most medicines, was necessary but not terribly popular and often difficult to administer due to entrenchment of the ills. In Columbia County, the problems are not so entrenched. There, the Boundary Commission can help the local government units avoid many of the pitfalls encountered by the rest of the metropolitan area. To us, this 'preventive medicine' approach makes good sense. We think the 1969 legislature was very perceptive in realizing that Columbia County was becoming strongly tied to the Portland metropolitan area and would be experiencing many of the same problems.9

Thus, while the appropriations bill was being held in Ways and Means, the supporters of the Commission went after the hearts and minds 
of the House membership with an approach which featured sound, reasoned arguments on what they considered the merits of the issues on which they were being challenged. The Magruder forces, however, never lost their control of the House majority which was holding the appropriation captive. While the Magruder forces did have a reasoned argument to support their position, they did not rely upon the pursuasiveness of their reasoning to hold the majority. Basically, they relied upon implicit and explicit vote-trading to gain the support of members who, when combined with those who supported the Magruder forces philosophically, gave them a majority. Put quite simply, a number of representatives who would be considered urban liberals and philosophically in support of land use and growth control agreed to support the removel of Columbia County in exchange for the support of the Magruder forces on legislation which affected them particularly or in exchange for agreement by the Magruder forces not to pursue legiglation which they considered harmful, such as S.B. 570 which would have emasculated the Land Conservation and Development Comnission. Most of these people felt that the removal of Columbia County was a very 'small price to pay for what they were getting in exchange. As in the Senate, there was never, at any time, a majority in the House in favor of abolishing the boundary commissions. The reasoned intellectual defense mounted by the Coumission and its supporters had solidified their support in both houses and a straight rote in both chambers on the question of continuing the conmissions as institutions, based on their merits, would have gone in their favor. This was not, hotever, the nature of the choice, or the basis of the choice facing the House. 
The question was the inclusion of Columbia County, not the continued extistence of the commissions generally or the Portiland Commission particularly, and the basis of the choice for most representatives was not the functional or operational merit of the commissions generally or the Portland Commission specifically, but was the relative benefits they perceived as a result of weighing the effects of removing columbia County against the effects of some one or more policy issues whose preferred fate could be made more likely by supporting Columbia County's removal. To the vast majority of the members of the House, the damaging effects on them particularly and on the public generally, of removing Columbia County from the Portland Commission's jurisdiction, was not very great. Concomitantly, the Magruder forces dia not have to offer much in exchange to make the tradeoff very attractive. The Comnission's supporters themselves made the very same type of calculation when they decided to support S.B. 1113, the removal of Columbia County, in exchange for the full biennial appropriation that maintained the cormissions as institutions. The reasons that the boundary commissions could be so vulnerable were to be found within the structure and function of the commissions, not in the clay feet of legislators. One of the important factors affecting the legislative welfare of the boundary commissions was the low level of information and interest on the part of most legislators. The invisibility had been a boon to those who maneuvered the original Boundary Commission Law through the 1969 session, but boon turned to bane by 1977 when there existed a small group of active opponents to offset the small group of active supporters with which the commissions had always been blessed. This invisibility 
had a number of negative effects upon the commissions' legislative welfare. One of the manifestations was the perception on the part of many legislators that the commissions were essentially land use planning bodies. The effect of this was not to contribute to its opponents, but to weaken its political support on the basis that it was seen as redundant to $L C D C$. The opponents took advantage of this situation by urging the consolidation of the commission with LCDC which they felt would at least reduce the number and effectiveness of agencies exercising land-use and growth control. In essence, this mistaken perception of the commissions made possible a coalition of those who opposed the commissions on a functional basis, as well as institutional, and those who were basically supportive of the commissions' functions but felt they could be performed adequately by a single institution-LCDC.

A major factor contributing to the lack of legislative visibility of the commissions is their regional structure. Many legislators have none or only a small part of their districts within boundary commission territories and have a concomitant lack of interest in the commissions' operations or welfare in a direct sense. These people are, in turn, espectally susceptible to tradeoffs between commission bills and other legislation which affects them more directly.

While invisibility and lack of statewide operation are important factors in explaining the legislative vulnerability of the comissions, the same factors apply to a number of state regulatory commissions to some degree, but those commissions do not necessarily exhibit the boundary commissions' political weakness. There is another factor which serves to separate the boundary commissions from those more fortunate. 
The Achilles' heel of the boundary commissions is that they lack a "politically effective" clientele. The commissions appear to serve the "general public" interest but they serve no private "special public" interest. They are not a steady and continuing source of goods or services to any identifiable group over time. Regulatory conmissions generally may seldom be the target of bouquets, but most of them have the good fortune of serving the interests directly of a special public which acts as their political advocate, especially if the special public is affected in the pocketbook. The boundary commissions do have a pocketbook effect, but these tend to balance out within their clientele and lead to political neutrality. The boundary comissions do have a significant effect upon the welfare of individuals and governments, but they do not affect the same individuals and governments over time and cannot, therefore, utilize them as a political base. Most of the commissions' relationships with individuals are ad hoc. The commissions do have continuing relationships with units of government, especially cities, and they have been politically supportive of the commissions. However, they are not an effective substitute for a private clientele because they have a political welfare of their own to protect and can afford to expend little of their political capital on the boundary commissions. No person or group of persons, other than commission members and commission employees, goes to the state legislature with a single-minded objective of protecting and preserving the boundary comissions. There is no "adrocato-clientele" in each legislator's district to inform and interest the legislator in the commissions' welfare. Exacerbating these problems is what some knowledgeable 
observers, Including the Portland Commission's first chairman, consider to be a failure to use the commissions' extsting sources of support effectively. He is of the opinion that the major problems of the 1977 session could have been avoided by a properly organized and managed effort on the part of the commissions themselves and their staffs. 10

This combination of factors stresses the fact that the political vulnerability of the boundary commissions is less a function of active opposition, than a lack of active support. The study and public hearings held by the Task Force on Boundary Commissions lends credence to this analysis. The Joint Interim Task Force on Boundary Commissions and Annexations was one of a number of task forces created by the House and Senate leadership under the authority of SJR56, 1977: "A list of subjects for study by each interim committee and the duration of the study shall be developed by the appointing authorities, in consultation with the appropriate committee chairperson." The official handbill announcing its creation stated its responsibilities as follows:

The Joint Interim Task Force on Boundary Comnissions and Annexations was formed December 1, 1977 to analyze and evaluate current functioning of Boundary Commissions to determine whether they are fulfilling their function. The Task Force was charged to recommend changes in current law or alternate methods for handling responsibilities assigned by law to such Cormissions and to review major annexation law problems.

The members appointed to the 90-day Task Force were: Senators Blaine Whipple, Chairmari; Tad Kulongoski; and Frank Roberts; Representatives Rod Monroe, Vice Chairman; Mary Burrows; Lloyd Kinsey; Glenn Otto; Wally Priestley; Al Riebel; and Glen Whallon. The Task Force evaluation of the boundary commissions took on even greater importance when Governor Straub vetoed S.B. 1113: 
Many of the local boundary issues in Columbia County have implications within the Portland metropolitan area. It is appropriate that these issues be resolved by an impartial body experienced in dealing with institutional alternatives to assure provision of needed services at a minimum cost in that region. Especially the southern cities of the countyScappoose, St, Helens, and Columbia City-feel the impact of metropolitan urbanization. However, an effort to modify this bill to leave those cities within the jurisdiction of the commission and withdraw only the more remote and mural north end of the county was unsuccessful in the legislative process.

Accordingly, a number of local officials in these cities, as well as boundary commission members and interested citizens have urged this veto. 11

The investigation of the boundary commissions by the Task Force can be considered the opening move of the legislative drama which is promised to engulf the commissions in the 1979 session.* If the analysis of the political valnerability is correct, the public hearings ought to exhibit little active opposition to the Portland Commission or to the comissions generally and a considerable amount of support from other units of government in the Portland metropolitan area.

The degree to which legislators were actively opposed to the boundary commissions was eloquently attested to by the Chairman of the Task Force on Boundary Commissions and Annexations, Blaine Whipple, when he summarized the testimony received by the Task Force relating to the question: are boundary commissions fulfilling their function?

*In an interview on May 4, 1978, Representative Dick Magruder, leader of the "Hornets" promised to lead an effort to eliminate the boundary commissions. He stated that he would no longer be satisfied with simply removing Columbia County. Subsequently, Representative Magruder failed to win renomination to his office. Shortly after that he was killed in a farm accident. The future of the "Hornets" as a political force is now very much in doubt, and their intentions toward the boundary commissions, if any, are not known. 
Chairman Whipple then asked if there were any members on the Task Force who felt that the boundary commissions were not fulfilling their function. He reminded the members that there were a number of bills introduced in the last session of the legislature by legislators who apparently did not feel that the boundary commissions were fulfilling their function. He recalled that the Task Force did not hear much adverse testimony from the legisiatoris against bounciary comilissions. Representative Bill Rogers, Representative Bob Vian and Senator Charles Hanlon were the only three to appear before the Joint Interim Task Force on Boundary Commissions and Annexations announced Chairman Whipple. Chairman Whipple stated that Representative Dick Magmuder had his leglalative assistant appear on his behalf, opposing the boundary commissions. The Chair suggested that the silence of the members on the question 'should boundary commissions be 12 eliminated?' was his indication that they should not be. 12

Even this statement overstates the degree of legislator opposition evidenced at the hearings and by witten testimony. Representative Vian did not actually oppose the functions and operations of the commissions: "Representative Vian said that he supports boundary cormissions and the idea of land use planning but he feels that the views of the public need to be taken into consideration." 13 "He feels, as last session, that the boundary commissions should be made up of elected officials, councilmen and county commissioners from each county." 14 Thus, he does not oppose the concept of boundary commissions, just the way the members are selected."15 Representative Rogers' opposition to the comnissions was not to their basic functions and operations but was based on what he considered to be their Inability to understand the needs of the people in rural eastem Lane County. ${ }^{16}$ Senator Hanlon, from Columbia County, did not question the necessity of the functions of the commissions, but he stated: "He and the people of Columbia County, are not set on the idea that a separate entity is needed for such decisions. $n^{17}$ The testimony offered by Representative Magruder's 
assistant, Brian Delashmutt, was that Columbia County was not an urban county and therefore did not require the use of a boundary commission, whose necessity in the urban counties he did not question. ${ }^{18}$ The Task Force did not receive from any legislator, either orally or in writing, a recormendation that the boundary commissions be abolished. This is not to say, however, that the commissions did not receive some opposition. It must also be recognised that the boundary commissions operate against a backdrop of generalized opposition, much of which is philosophically based. This kind of opposition exists with respect to any regulatory body and is a product of their operation. Regulatory bodies restrict and restrain people's actions and from time to time prevent them from doing what they want to do. This inevitably generates hostility. The hostility is exacerbated in the case of the boundary comnissions because they often prevent a land owner from using his land the way he wants to and interference by government in this area of individual action is especially disliked by most people. Thus, there are specific individuals whose preferences have been denied by the commissions and they are angry. Also, those whose business it is to engage in land and property development are, as a group, generally hostile to the boundary commissions because they are generally opposed to any kind of govermmental control over their actions. Active and public opposition to all three commissions came primarily from two sources.

Both the Lane County and Portland Comissions have considerable opposition coming from the rural parts of their jurisdictions. The opposition to the Lane County Commission came from both the eastern and 
western ends of the county. Opposition seems to be centered in the Florence and Dunes City area in the west and each of these cities wrote letters to the Task Force opposing their inclusion within the jurisdiction of the urban Eugene-based Lane County Boundary Commission. ${ }^{19}$ The Columbia County Board of Commissioners made the same point with respect to the Portland Commission:

2. We feel that it makes little sense for predominantly rural Columbia County to be controlled by the Portland Metropolitan Boundary Commission. Only one area in the county is affected by Portland's growth. 20 Finally, the political realities are such that people in Columbia County are not only offended but seriously inconvenienced by the prospect of a governing body in Portland dealing with purely local matters. A typical question that highights the concern is: 'Why should people in the Clatskanie area have to bring their local issues before a legislative group in Portland whihe [8ic] is eighty miles away and in a very different political, social, and physical setting?' We have to sympathize with those asking that question. 21

Emphasizing the rural and remote basis of the plea were two letters from officials of cities in Columbia County which are located near the Portland boundary, which opposed the removal of all of Columbia County. 22

The second source of opposition also had a partially rural-remote basis but was more a function of the Boundary Commission Law and its effect upon rural fire protection districts. Each of the comnissions was subject to bitter complaints from fire districts. These districts are very upset by their loss of service territory to cities through the process of annexation, a process which they feel the comissions have contributed to by their espousal of cities as "logical providers" of urban services. Unlike water and sewer districts, fire districts automatically lose service territories annexed by cities unless the city 1s, 
or agrees to be, a part of the district. ${ }^{23}$ The Portland Boundary Commission was vehemently denounced by a number of Clackamas County RFPDs as being a tool of the cities and of violating both the letter and the spirit of the Boundary Commission Law in imposing its pro-city policy. ${ }^{24}$ A contributor to this point of view was a draft of Suggested Policy on General Purpose Government, Revised October 19, 1977, in which the Portland Comission would have formally promulgated a policy which would have made special districts a last resort in the provision of urban services. In a letter to the Task Force, the Board of Clackamas County Fire Districts No. 1 stated: " . . it appears that the boundary commission and CRAG and the League of Oregon Cities is trying to mandate annexation by whatever means are available." 25 Thus, the only significant opposition to, or dissatisfaction with, the boundary comissions generally and the Portland Commission particularly were from these two sources: (1) Rural areas and cities within those rural areas, located at long distances from the major city of the commission's jurisdiction, whose position was primarily that they be removed from boundary commission jurisdiction; and (2) fire districts contiguous to existing cities which are losing service territory to the cities through annexation. These complaints were to some extent offset by testimony from some fire districts which viewed the boundary comnissions as a positive force in attempting to bring about consolidation of small inefficient fire districts. ${ }^{26}$ The situation with water districts was quite the opposite, with criticism coming from small districts and support coming from large consolidated water districts. ${ }^{27}$ It is quite clear that the position of the large and amall water and 
fire districts was determined by their perception of annexation and consolidation. Large fire districts and small water districts in east Multnomah and north Clackamas counties are contiguous to a number of cities which have active annexation programs and fear annexation and consolidation as threats to their existence. Of the total 174 annexations proposed during the 1975-1977 biennium, 106 were to cities in Multnomah and Clackamas counties. Large water districts exist mostly in Washington County and they have little to fear from city annexation. The city of Tigard, which abuts the Tigard Water District, does not have a municipal water system and the city of Beaverton which is in the water business and abuts the Wolf Creek Water District does not have an active annexation program. In the 1975-1977 biennium, the city of Beaverton had only three annexations, totaling 20 acres and two dwelling units with a total population of five. The massive size of these districts also lessens their fear of annexation and they themselves are active annexationists. Of the total 46 annexations to water districts during the 1975-1977 biennium, 23 were from the Tigard and Wolf Creek Districts. Wolf Creek is the third largest provider of water in the State of Oregon. The large water districts and small fire districts saw annexation and consolidation as being in their best interests and supported the boundary commissions.

In a letter to the Task Force, Robert Santee, Administrator of the Tigard Water District, a very large district, stated:

My association with the Boundary Review Commission dates back to its inception in 1969. At that time, boundaries of the Tigard Water District were atrocious with at least forty (40) separate islands within the district. With the guidance and assistance of the, then, newly formed Boundary Comnission, we were able to 
correct illogical boundaries expeditiously and make the administration of the district manageable.

Testimony critical of the commissions from sources other than units of government was minimal. The Oregon Homebuilders Association testified in opposition to the commissions generally, on the basis that they were redundant and the comprehensive plans and LCDC were enough control. 28 The Portland Homebuilders Association did not, hovever, oppose the Portland Commission and it does not actively support the outspoken opposition to the commissions on the part of the State Association. 29 Testimony was offered by legal counsel for Housing Resources Corporation whose stated concern was that the commissions' operations restrict the supply of buildable land and available housing. 30 An attorney representing a flrm of consulting engineers testified that the commissions' operations were capricious; the standards in the statute were too broad, that economic criteria should be extended; and most importantly, that the commissions failed to provide "due process" to those who came before them and that this should be corrected by providing for subpoena powers, direct cross examination and challenges. 31

With respect to other units of government, the testimony, both oral and written, was almost universally favorable and came from all levels-regional, county and city. 32 Nothing, however, is more favorable than the Final Policy Statement adopted by the Joint Interim Task Force. While the twenty-six points do contain elements which propose further study, the tenor of the policies is unmistakable and rather than posing a substantial threat to the commissions as institutions, give them a vote of confidence. Indeed, they go as far as 
recomnending the creation of additional boundary commissions. Points one and two recommend the establishment of commissions in the LinnBenton county area and the addition of Yamhill County to the Marion-Polk County Commission respectively. Points three and four recommend a study of an Oregon coastal zone boundary commission and a Jackson-Josephine County comission, respectively. 33 Both the Portland and Lane County commissions are affected by points which may remove the western sections of their jurisdictions and include those areas within northerm and southern coastal boundary comissions. Point three: A study be undertaken to create boundary commissions in the Oregon coastal zone. This might necessitate splitting the Lane County Local Government Boundary Comission at the Coastal Mountain Range, and point five: A study of redrawing the boundaries of the Portland Metropolitan Area Boundary Commission as it affects Columbia County. 34 Nevertheless, when considered together, the judgment must be made that in the promised boundary comnission battle of 1979 to be held in the legislative arena, the commissions have won the first round. 
FOOTNOTES

1. Rick Gustafson, Private interview via telephone, Portland, May 4, 1978.

2. S.B. 5544, Oregon Legislative Assembly, 1977 Regular Session.

3. Journals and Calendars of the Senate and House, Regular Session, (Salem: 59th Legislative Assembly, 1977), p. 48.

4. Ibid., p. 47 .

5. Ibid., p. 47.

6. Dick Magruder, Private interview via telephone, Portland and Clatskanie, May 4, 1978.

7. Rick Gustafson, Private interview via telephone, Portland, May 4, 1978.

8. Carolyn Gassaway, Letter from Carolyn Gassaway, Chairman, Portland Boundary Commission, to members of the Oregon State Senate, June 2l, 1977, Portland, Portland Boundary Cormission files, p. 3.

9. Ibid., p. 1 .

10. Ronald C. Cease, Private interview, Portland, August 4, 1978.

11. Robert Straub, Veto message, S.B. 1113, from Governor Straub to Secretary of State Norma Pauzis, July 26, 1977, Salem, Oregon State Library.

12. Task Force on Boundary Commissions and Annexations, "Minutes," February 9, 1978, Salem, Task Force files, Item 434, p. 8.

13. Task Force on Boundary Commissions and Annexstions, "Minutes," January 12, 1978, Salem, Task Force files, p. 7.

14. Iblde, p. 4 .

15. Ibid., p. 7 .

16. Task Force on Boundary Commissions and Annexations, "Minutes," January 26, 1978, Salem, Task Force files, pp. 3, 4, 5, 6.

17. Task Force on Boundary Commissions and Annexations, "Minutes." January 19, 1978, Salem, Task Force files, p. 7. 
18. Task Force on Boundary Commisstons and Annexations, "Miñutes," December 14, 1977, Salem, Task Force files, p. 6.

19. The Common Council of Florence, Letter to the Task Force on Boundary Commissions and Annexations, January 23, 1978, Salem, Task Force files. The Mayor of Dunes City, Letter to the Task Force on Boundary Commissions and Annexations, January 25, 1978, Salem, Task Force files.

20. Columbia County Board of Comissioners, Letter to Task Force on Boundary Commissions and Annexations, December 14, 1977, Selem, Task Force files.

22. Ibid.

22. Red Norwood, Mayor of the City of St. Helens, Letter to the Task Force on Boundary Commissions and Annexations, January 23, 1978, Salem, Task Force files. Stan Pintarich, Scappoose City Councilman, Letter to Governor Straub, July 18, 1977, Salem, Task Force files.

23. ORS 199.510(2). ORS 199.510(2)(a). ORS 199.510(2)(b).

24. James Dille, Board Chairman, Clackamas Flre District No. 71, Letter to Task Force on Boundary Commissions and Annexations, February 2, 1978, Salem, Task Force files. Joe W. Provost, Fire Chief, Clackamas Fire District No. 71, Letter to Task Force on Boundary Commissions and Annexations, February 2, 1978, Salem, Task Force files. Virgil R. English, Director, Oregon Fire District Directors Association, Letter to Task Force on Boundary Commissions and Annexations, January 29, 1978, Salem, Task Force files. Task Force on Boundary Commissions and Annexations, "Minutes," Testimony of Harry Carpenter, Chief, Clackamas County Fire District No. I, January 12, 1978, Salem, Trsk Force files, p. 11.

25. Clackamas County Fire District No. 1, Letter to Task Force on Boundary Commissions and Annexations, January 12, 1978, Salem, Task Force files, p. 1 .

26. Sandy Fire District No. 72, Letter to Task Force on Boundary Commissions and Annexations, January 23, 1978, Salem, Task Force files. Jack R. Crescenzi, Fire Chief, Beavercreek RFPD No. 55, Letter to Task Force on Boundary Commissions and Annexations, January 18, 1978, Salem, Task Force files.

27. Robert Santee, Administrator, Tigard Water District, Letter to Task Force on Boundary Commissions and Annexations, Jenuary 19, 1978, Salem, Task Force files. Gene Seibel, Assistant Administrator, Wolf Creek Highway Water District, Letter to Task Force on Boundary Commissions and Annexations, January 19, 1978, Salem, Task Force files. Task Force on Boundary Commissions and Annexations, "Minutes," Testimony of George Bimie, Tri-County Water District Association, January 12, 1978, Salem, Task Force flles, p. 5. 
Task Force on Boundary Commissions and Annexations, "Minutes," Testimony of John McDonald, Chairman, North Clackamas County Water District Association and Chairman of the Board, Stanley Water District, January 19, 1978, Salem, Task Force files, p. 11.

28. Task Force on Boundary Commissions and Annexations, "Minutes," Testimony of Mr. Van Natta, Oregon Homebuilders Association, December 14, 1977, Salem, Task Force flles, p. 5.

29. Burton Weast, Director, Portland Homebuilders Association, Private interview via telephone, Portland, May 5, 1978.

30. Task Force on Boundary Commissions and Annexations, "Minutes," Testimony of Terry Morgan, January 19, 1978, Salem, Task Force files, $p=$ ?.

31. Task Force on Boundary Commissions and Annexations, "Minutes," Testimony of Diane Spies, January 19, 1978, Salem, Task Force files, p. 3.

32. Task Force on Boundary Commlssions and Annexations, "Minutes," Testimony and printed statement of Corky Kirkpatrick, Chairman, CRAG Board of Directors, January 19, 1978, Salem, Task Force files, Exhibit F, p. 10. Task Force on Boundary Commissions and Annexations, "Minutes," Testimony of Dennis MeCaffrey, Polk County, January 12, 1978, Salem, Task Force files, p. 2. Task Force on Boundary Commissions and Annexations, "Minutes," Testimony of Ed Crampton, Mul tnomah County, February 2, 1978, Salem, Task Force files. Task Force on Boundary Commissions and Annexations, "Miriates," Testimony of Fidon Mills, City Manager, Hillsboro, January 19, 1978, Salem, Task Force files, p. 8. Task Force on Boundary Commissions and Annexations, "Minutes," Testimony of Aldie Howard, City of Tigard, January 19, 1978, Sal em, Task Force files, p. 10. Task Force on Boundary Commissions and Annexations, "Minutes," Testimony of Charles Henry, City Manager, Eugene, January 26, 1978, Salem, Task Force files, p. \% I'ask Force on Boundary Commissions and Annexations, "Minutes," Testimony of Neil Goldschmidt, Mayor, City of Portland, February 2, 1978, Salem, Task Force files.

33. Appendix, p. 239.

34. Ibid., p. 239. 
CHAPTER IX

THE COMMISSION AND THE STAFF

A. McKay Rich, Executive Director, of the Portland Metropolitan
Study Commission (FMSC), and Marilyn Gunsul, did not leave the choice
of chairman of the Commission to chance and sought successfully to
assist the laws of probability in electing Dr. Ronald Cease as the first chairman. Rich, Cease, and others who had been involved with the design and development of the Commission wanted to see the Commission start off on the right path and the election of Cease as chairman put the only person with previous boundary commission experience in the saddle. While no one else on the original Commission had direct boundary commission experience, a number of them had considerable expertise on the subject of local government. The original Commission had two college professors in addition to Cease, all of whom had considerable expertise in local government issues. Some others had gained experience in serving on local govermment related comittees of such organizations as the Chamber of Commerce and the League of Women Voters. Still others were involved with local governments in the normal course of their professional careers. ${ }^{1}$

Nevertheless, there did exist in those first formative years of the Comission a like-minded, traditionally-oriented, leadership group consisting of Cease, the chairman; Rich of the PMSC; Pete Hollick, Executive Officer of the Conmission; and Don Carlson, Executive 
Assistant of the Comission. Both Hollick and Carlson had advanced degrees in public administration, and Carlson had been an assistant to Rich on the PMSC and had been involved in the design and development of the Boundary Commission Law. All four of them had received academic training in the subject of local government and shared common ideas shaped by the "political reform tradition" paradigm. Included within this set of ideas were a commitment to "regionalism" and to the prevention of "fragmentation" and "duplication" in the local government system and this point of view was very much in keeping with the philosophy which lay behind the Boundary Commission Law itself. This academically trained leadership set the tone for the Commission's operations during the formative years and served to educate the other members of the Commission with respect to the structure and function of local government and the problems therein, and the role the Commission ought to play in shaping the system of local government within its jurisdiction. Although Rich was not a member of the Commission or the staff, he did have a considerable impact on its early development because of his long involvement in the Commission's formation and his close relationship with the Commission's Chairman Cease and the Commission staff. The PMSC also provided early assistance to the Commission until it had developed its staff to the point where the staff could carry out the Commission's mandated responsibilities.

The personal and philosophical compatability among the leadership group spread throughout the membership and set a tone for the internal relationships of the Commission which remains in force today. The relationships among the members are cordial and tolerant. While there 
may be differences in political philosophy among the members, these are not allowed to corrode the relations on a personal level. There was from the beginning a strong feeling of comaraderie in which each commissioner perceived himself or herself as part of a group which had a mission to accomplish-a mission in which each of them believed. Exogenous events also served to shape the early history of the Commission. The socialization of the Commission took place through a number of agents, including the leadership group, peer relations generally, and the public through the public hearing process. The fact that the leadership group was based upon knowledge and expertise and depended upon persuasion rather than coercion to achieve its ends set a pattern that spread throughout the Commission and was reinforced by similar peer relations. Each member gave and expected the respect of the others, and this developing in-group feeling was solidified by events which threatened the Commission, at times to the extent of bodily harm, and served to make the members aware that their main source of support would often be one another.

One of the early events which shaped the Commission's operations was a meeting held in the Public Service Building in downtown Portland which turned out to be a debacle and caused the Commission to re-evaluate its procedures. The difficulties began when the Commission held a private meeting before the public hearing. The meeting took place behind the stage curtain serving as a backdrop to the podium on which the Commission would be placed for the public hearing. Unbeknownst to the Commission, the audience which was gathering for the public hearing was able to hear the discussion being held behind the 
curtain. This caused the Commission considerable embarrassment when they realized that their discussion was being punctuated by outbursts of laughter from the auditorium because the audience was privy to their "private" discussion. During the public hearing, the Commission was faced with a very forceful presentation by a local public official, a presentation which the Chairman considered to be browbeating and intimidating. It also appeared to the Chairman that the Commission was beginning to fold under the pressure. At 10:00 $\mathrm{p}_{\bullet} \mathrm{m}_{\bullet}$, in the middle of the hearing; the lights in the auditorium suddenly dimmed and a great noise from some type of motorized equipment began. The Commission was apparently unaware that the Public Service Building auditorium had a closing time of 10:00 p.m. and had not arranged to have it extended. The building maintenance people simply began to clean the auditorium area at the normal closing hour. It was clear to Chairman Cease that the public hearing could not continue. This gave him cause to adjourn the hearing and continue all business forward to the next meeting. It also provided him with an opportunity to head off a decision which he felt would have been made solely on the basis of the intensity of the public hearing. Before the next meeting, Chairman Cease, Marilyn Gunsul, other Commission members, and the staff met to develop new procedures which they felt would "tighten up" the procedure to avoid another such debacle. The most significant procedural change to come out of this was the development of a meeting to be held before each public hearing at which the staff would brief the Comnissioners on each agenda item, as it was felt by the Chairman and others that the Commission's susceptibility to the pressure at the public hearing was 
primarily due to its lack of knowledge about the proposal. The commissioners do not, of course, make formal decisions during these sessions but there is an interchange between the staff and the commissioners and among the commissioners and this provides them with an informational and attitudinal background against which to hear and evaluate public testimony during the hearing.

Another event which shaped the Commission's operations came when the Commission in following its policy of holding public hearings around the district held a hearing in the Frrol Heights area where it was to take public testimony on a proposal to annex Errol Heights to the City of Portland, a proposal which the Commission itself had initiated. Because the public turnout was unexpectedly large, the hearing had to be moved to a larger room than originally scheduled. Unfortunately, the public address system in the larger room was not operating and this made it necessary for the commissioners and the public to raise their voices when talking to one another and this served to exacerbate the already existing ill will of the audience toward the Commission. The public present at the public hearing was adamently opposed to the proposal. Chairman Cease had to "threaten" to recess the hearing to get the crowd to settle down and this situation was made worse by the presence of an inebriate in the back of the room who hurled epithets at the Commission throughout the hearing. The situation was so bad that several members of the Conmission subsequently indicated that they had been physically afraid.

Chairman Cease, who had been an outspoken supporter of a policy of holding meetings and public hearings out in the district, found 
himself outvoted by a frightened Commission which voted to hold all of its regular public hearings in the Multnomah County Courthouse henceforth. Some members had always been in favor of the Courthouse because of its convenient central location. This policy has had negative repercussions of its own, particularly in isolating the Commission from its more distant constituents. Another ramification of this debacle was to discourage the Commission from initiating large-scale proposals on its own, a trend which was further emphasized by the fate of later proposals to unify water and fire districts in north Clackamas County which also received a very hostile public reception.

These events and the reaction to them contributed to the development of a Portland Boundary Commission "way of doing things." While the Boundary Commission Law mandates a procedure to be followed by the Commission, it was skeletal enough that the Commission had a number of alternatives available on most procedural questions. It must be recognized that the original Commission and the original leadership had to develop from this skeletal legal framework a "way of doing things," a method or pattern of operation. Members who have been subsequently appointed to the Commission have had the advantage of moving to a body which has a history and a developed process. The formal process of educating new comissioners is, however, minimal, usually consisting of a preliminary luncheon with Don Carlson and perhaps the chairman at which the new commissioner is introduced to the Boundary Commission Law, given a brief history of the Commission, and informed of the major projects or challenges in which the Commission is currently involved. A copy of the most recent Report and Statistical 
Summary of the Commission is provided at that time. Aside from this, there is no formal training or indoctrination provided for new members. Some members in the past had the good fortune to attend retreats and seminars held by the Commission shortly after their appointment, which they found very helpful, but these have not been held for several years. Most of the educational activities in which the Commission was involved in its earlier years, such as retreats, seminars and meetings with other agencies, are no longer being pushed by the staff as they were in the early years of the Commission. This is because the excitement of learning together is no more, the staff has "heard it all before." The difficulty with this is that new members of the Commission have not "heard it all before" and what may be "old hat" to the staff might well be very educational for the newer commissioners. Because of the absence of a formal training process, most comissioners report they were very inactive during their first few months of service on the Commission. They felt they were undergoing "on the job" training and were serving a voluntary and prudential apprenticeship. No member, however, ever felt this behavior was expected of them. No commissioners reported they ever felt any peer pressure not to participate even when they first joined the Commission. Each commissioner believes he or she joined the Commission as a full-fledged member. In addition, no commissioner reported ever feeling there was a "pecking order" on the Commission.

Jerry Tippins, a prominent newspaper editor, who served as the second chairman of the Commission, characterized the early leadership of the Comission as "tolerant, patient, courteous, and activist," and 
there are no voices among the original comissioners in disagreement with him on these points. ${ }^{2}$ A major contributor to this harmony was the absence of deep seated or long term differences among the commissioners on the basis of substantive or procedural policy. Like society itself, the Commission had its "Ieft" and "right" during the early period with the presence of a "conservative business-development" group and a "liberal-environmentalist" group. Most of the members of the original Commission characterize this division in terms of how the members perceived the proposals and persons they were dealing with. Former Chairman Jerry Tippins described these perceptions as follows:

Where a "conservative-business" member would perceive a hard working developer who has taken all of the necessary steps in clearing all of the hurdles, who wants to develop a piece of property and provide housing and employment and contribute to the economy while making a reasonable profit; the "liberalenvironmentalist" member might perceive a manipulator who wants to build a "leap frog" development on cheap land which destroys farm land and contributes to "urban sprawl" by fragmenting governmental structure while providing inadequate and inefficient services. 3

While these may be polar examples, they are illustrative of the selective perception tendencies of the ideologies in question. Though this basic division existed, it did not often intrude upon the Commission operations. When it did, it was usually very low key, and it was often the basis for good natured jesting among the commissioners. No one who was on the Commission at that time believes that anyone was predictable. The Commission was usually unified on most decisions but when it was not, the members generally felt the divisions to be ad hoc. The ideological division of the Commission never reached the point where it served as the predominant basis for decision making. 
One area where this division manifested itself was during the period before the existence of the Columbia Region Association of Governments (CRAG) and later the Land Conservation and Development Commission (ICDC) when there was no comprehensive planning to guide the Commission as there is now. The Commission had no express power to plan land use and no staff to do it with, but the Commission could not avoid the fact that many of the boundary change proposals coming before it had profound and direct land use implications, especially those which had as their purpose the conversion of raw farm land to urban use. In such cases, the Commission would often make a decision based partly on its own belief's about how such land ought to be used. This situation tended to divide the Commission both as to the substantive question of how the land in question ought to be used and the procedural question of whether the Comilission ought to be making such a substentive decision. The procedural concern was felt most by those in the "conservative-business" group. The effect of such situations was mitigated by the unifying tendencies of what most of the original commissioners considered to be the Commission's primary area of concern: governmental structure. Not only did the early commissioners agree on governmental structure as the central concern of the Commission, they were also very much in agreement about the dimensions of the problem, its definition, and on the remedy to be pursued. The "political reform tradition" approach of the leadership group found favor with members across the ideological spectrum. Members from both groups found this approach compatible with their ideologies.

The more recent Commission members have a different image of the 
major roles of the Commission and the divisions within 1t. To begin with, the more recent commissioners and those whose tenure on the Commission encompasses both the early and later periods, present a current picture of the Commission as being much more complex than it was in the early period. This is in conformance with the discussion of Commission policy which potnted out the increasing scale and complexity of the Commission's analysis and evaluation of proposals. The list of factors applied to each proposal in the early period was much less complex. The principal contributor to this increasing complexity has been the multiplication of land use planning criteria which the Commission applies to proposals. Commissioners whose tenure spanned both the early and late periods tend to speak longingly of earlier, simpler times. Nevertheless, these same people also point out the lack of guidelines available to them in those early days, especially with respect to land use planning. Thus, it appears that at least in the minds of the long term commissioners, the exogenously supplied criteria for land use has gone from famine to glut, and the decisionmaking process of the Commission from simple to complex.

The role of the Commission as an implementor of state and local land use criteris and the resulting increase in complexity would have served to increase the divisions within the Commission if the division based on "conservative-business" versus "liberal-environmentalist" Iines had remained in place in the more recent era. Such, however, was not the case. A basic shlft has taken place in the makeup of the Commission which has resulted in a diminution of those points of view which have been characterized as "conservative-business." While there 
are several members of the Commission today who have at least one foot in the business world in pursuing their livelihood, there is no one who could be said to have been appointed because he or she was well known in such circles. Those who have such business connections were appointed to the Commission not because of those business interests or connections, but because they had made their public name in an area other than business, such as membership on a city or county planning comnission. Thus, the Commission presently lacks representation from what might be termed the "old line, downtown, conservative, Republican, business" segment of society.

This is not to say, however, that with the passing of the "conservative-business" point of view, division on the Commission ceased to exist. It remains, but it has changed form. Division within the Commission has changed from what might be characterized as a difference "in kind" to a difference "in degree." Once one side of the original division ceased to exist, the remaining side divided to form a new division. This new division separates a body of members all of whom are supportive of land use planning, growth control, urban containment, nonpoliution of the environment, and a host of other concerns which, taken together, constitute what has been termed the "liberalenvironmentalist" point of view. This new division separates them on the basis of the intensity of the application of these points of view to the proposals under review. One group of commissioners tends to apply existing criteria and standards very rigorously while the other tends to be more flexible in their application. As with the earlier type of division, this split tends to manifest itself most in those 
cases which involve land use planning, espectally where it involves the conversion of raw land to urban use. Ceses primarily decided on the basis of governmental structure or the provision of services, tend as before, not to divide the Commission on other than ad hoc lines. The effects of these trends of increasing complexdty and a divisional shift from an "in kind" to an "in degree" basis, can be seen in the comments of past and present commissioners about the presence of "opinion leaders" on the Commission, both as to who they were and why they were such leaders. Discussion of "opinion leaders" with the commissioners quickly brings out the unanimous opinion that at no time has any one or a few members dominated the Commission. Nevertheless, all members queried were able to respond readily with a set of names and the reasons why said persons were "cpinion leaders." Two points emerge quite clearly from these discussions. First, the type of members most frequently mentioned as "opinion leaders" has changed over time in a way which conforms with the trends of complexity and divisional shift. Second, members view the primary basis of "opinion leadership" to be the expertise the member brings to the Commission and not personality characteristics. The change in the type of expertise recognized as leading to "opinion leadership" also dovetails with these other trends.

Consensus choices as "opinion leaders" during the early period of the Conmission reflect the early "liberal-environmentalist" versus "conservative-business" division. Primary spokesmen for the "liberalenvironmenta]" group were Ron Cease, Jerry Tippins and Tony Federici, all of whom were recognized as having demonstrated competence on the 
issues of governmental structure and organization and politics. Primary spokesmen for the "conservative-business" group were Richard Brown, John Crawford, and Campbell Richardson, all of whom were recognized as having special knowledge of business, finance, and development. That the first three chairmen of the Commission came from the "liberal-environmental" group-Cease, Tippins and Federici-indicates that this group had the upper hand in most cases where the division manifested itself.

Consensus choices as "opinion leaders" in the later period reflect the newer division. Most frequently mentioned as an "opinion leader" and spokesman for the group which tends to be more flexible in implementing criteria and standards is Robert Ball who is regarded as having special expertise in land use planning and the legal aspects of the Commission's operations. Ball is an attormey and a former member of the City of Tigard planning comission. The primary spokesman for those who would implement criteria and standards most rigorously and intensely is Peter McDonald who is recognized as having land use expertise and planning experience, having been a member of the Clackamas County planning comnission. Ron Cease and Tony Federici continue to be recognized as "opinion leaders" but they are now considered to be leaders of a swing group between the other two. Among current members, their influence is attributed to political expertise and sensitivity, both of them being very much involved in local politics. Tony Federici is also accorded extraordinary influence on proposals in Columbia County and serves as a geographically based "opinion leader" on those issues. No other person or area is treated in this manner at present, 
but Donovan Blair and Polly Casterline who were from east Multnoman County also played this kind of role when they were on the Commission. Many members are of the opinion that the qualities and expertise of the lawyers on the Commission are making them relatively more important as "opinion leaders." Legal expertise and legal reasoning are viewed by many members as playing an increasing role in the Commission's operations and members with these credentials will inevitably be "opinion leaders." This opinion is combined in the minds of many of the commissioners with a feeling that the Commission has become more rigid and bureaucratized in its operation. To a significant extent, this is due to a change in the environment in which it operates. Through such decistions as Fasano and Peterson the Oregon courts have caused the land use decision-making process generally to become more rigid and structured. ${ }^{4}$ Because of its role as an implementor of land use policy, the Commission has been affected by these changes and the formal-legal constraints have resulted in a diminution of their discretion. As the number of exogenously supplied rules, goals, guidelines, and plans has increased, many members have begun to feel that their role was changing from one in which they made "informed judgments" to one in which they made "mechanistic calculations" devoid of an input of their own personal judgment. Nevertheless, most current members believe that the discretion remaining and judgment required in making decisions, given the structure, was still considerable. All of the members, past and present, feel that the Commission is a powerful institution making important decisions.

In discussing the Commission with many commissioners, past and 
present, some of whom have served on the Comission throughout its history, these have been the dominant themes. The proposals, problems, and issues the Commission faces have become much more complex. The basis of division within the Commission has shifted from an "in kind" basis to an "in degree" basis. The working environment of the Commission has become more bureaucratic and routine and personal judgment is not as important as it once was. The membership of the Commission has become more like-minded and the early business oriented elements no longer exist. The increasing complexity, rigidity, and legality of the Commission's operations has made the talents of lawyers relatively more important as leaders of the Commission.

The commissioners and the staff are in agreament on the present methods of staff operation. Both agree the staff has a responsibility to make recommendations for the disposition of proposals and to defend those recommendations on the basis of the findings in the staff report prepared for each proposal. Both the commissioners and the staff believe that the staff has a responsibility to provide the commissioners with high quality, objective, informative staff reports. Neither the staff nor the commissioners believe the staff reports are biased to support the staff recommendation. The staff believes it supplies, and the Commission is convinced it receives, honest information and reconmendations in the staff reports. This belief that the staff has always been honest and hard working is held nearly universally by commigsioners, past and present, conservative and liberal. Even those members who feel the staff point of view tends not to conform to their own believe the staff is honest and reject the notion that the staff 
might be biased toward other commissioners who share the staff point of view. The staff clatms not to be, and the comissioners express no belief that the staff pitches its reports and recommendations toward any commissioner or group of commissioners. In short, no member of the Commission, past or present, believes the staff has used its control over information in the staff reports to attempt to manipulate the Commission.

In addition, the commissioners are adamant about their belief that the commissioners arrived at their decisions on the basis of a number of inputs. While the staff report was admitted to be very important, the commissioners very strongly believed the public hearings served to supplement the staff report where it might have omitted important facts, to correct the staff report where it might be factually mistaken, and to unmask any attempt by the staff to intentionally deceive the Commission. While most commissioners felt they voted with the staff recommendation most of the time, they were not at all hesitant to vote against the recommendations and were quick to point out that such occurrences are not at all unusual. As might be expected, the commissioners are very hostile to any implication the staff might be running the Cormission, a situation not uncommon where there is a fulltime staff and a part-time Comnission, and buttress their denial of such a situation by pointing out the frequency with which the Commission takes action not in accordance with staff recommendations. The staff is also very conscious of this relationship and Don Carlson makes it clear to his staff that they are not the Commission and they must be careful not to usurp the Commission's prerogatives. Carlson, because of his 
participation in the meetings and hearings, admits to being extraordinarily conscious of the possibility of overstepping the bounds of staff and intruding into Commission territory. Several commissioners also feel the staff occasionally forgets its place and intrudes too much into the discussion of proposals in the public hearings. Both the commissioners and the staff are cognizant of the difficulty of both establishing a precise line between them and of avoiding the temptation to cross, especially in the heat of battle. Except for the perception by a few commissioners of an occasional misstep, the Commission could be said to be very much of the opinion the staff "knows its place."

All of the members of the staff receive highest praise from both past and present members of the Commission including past and present chairmen who have always had responsibility for direct administration of the staff. Centralizing administrative control in the chairman was a policy adopted during the chairmanship of Cease. Each chairman reports, however, that the staff is essentially self-regulating and selfdirecting. Chairman Tippins spoke for all the chairmen when he said, "If you have a good staff in which you have confidence, then there is little need for active control by the chairman. " 5 At no time has any of the chairmen or any other commissioner attempted to directly control the operation of the staff; Carlson and his predecessor Phil Hollick have always had plenary powers over office management. The chairman works most closely and actively with the staff during the legislative year when the Commission budget and Commission related legislation is being processed. As the Commission has matured and developed routine modes of operation, the chairman has become progressively less involved in the 
staff operation. Again, the basic patterns of the administrative control of the staff were set during the chairmansinip of Cease and have remained undisturbed since that time. Cease set the patterns for the relationship between the staff and the Commission and based upon reports of the commissioners these have provided to be highly satisfactory. While it is always difficult to assess the effects of individual personalities upon institutions, in the case of Chairman Cease, there were three factors which contributed to his influence. First, he was the first chairman of a new commission and this situation gave him the opportunity to set the course of the Commission, both internally and externally, without first having to overcome defenders of the status quo. Second, he had a greater relative advantage in information and expertise as to boundary commissions than any chairman or regular member since that time. Third, he is the only commissioner ever to have served in a staff position to a boundary commission before becoming a commissioner. Thus, he not only had an advantage over the other commissioners but the original staff as well, because nelther Hollick nor Carlson had served as staff to a boundary commission previously. This put Cease in a position to know the pitfalls of staff-commission relations and to purposefully avoid them. Because of his direct experience, he knew how a staff might come to dominate a commission and took steps to avoid such a situation developing. His lack of dependence upon the staff for expertise aided him greatly in this regard. Having such a person with this fortunate and unusual combination of characteristics had a great deal to do with the fact that the Commission has not had many of the problems that often exist with a part-time, lay comnission and a 
full-time, professional staff.

There is one area of Commission operation in which the lines of demarcation between staff and Commission have become blurred and this situation and its difficulties are apparent to both the staff and the commissioners. In the early days of the Commission under the Republican McCall administration, Robert Logan of the State Local Government Relations Division handled the appointment process. The only Commission or staff involvement would be to notify Logan of the vacancy and the geographic area from which the position should be filled and Logan would take care of the rest. When the Denocratic Straub administration first took office, a number of appointments to the Commission were made in its first few months in office. After its initial flurry of appointments, the Straub administration began to fall behind in making appointments. At times, the ranks were so depleted that a quorum sufficient to issue final orders-six-was barely attainable due to the combination of unfilled positions and absentees. After a number of unsuccessful attempts to speed up the appointment process, the staff solicited names from the commissioners and sent a list to the Governor's Office from which some appointments were eventually made. Thus, the staff has, by default, had to enter into the appointment process to the extent that it may be susceptible to charges of having created a commission in its own image, ard the staff is very uncomfortable about the situation. No commissioner, however, past or present, feels that this has been the case.

In addition to the functional role the staff plays within the Commission, the staff also acts as an extension of the Commission with 
respect to private individuals, agencies of government, and other units of government. One of the more important exogenous functions of the staff is to represent the Commission in dealings with other agencies and units of government. This runs the gamut from "showing the flag" at planning meetings of cities and counties within the district at which Carlson, the usual representative, would play no active role, to dealing with the staff of the ICDC to determine how the LCDC would have the Commission interpret and implement the ICDC goals and guidelines. Members of the Commission generally, and chairmen specifically, have been pleased with the job the staff and particularly the Executive Officers Hollick and Carlson had done in representing and acting for the Commission in its relationships with other agencies and governments and the State legislature. Perhaps the major reason why this aspect of the Commission operation has always gone well is that the early leadership of the Commission was very much a part of local government and politics and had close working relations with those involved with other institutions in the Portland area such as A. McKay Rich of the PMSC, Homer Chandler of CRAG, and others. Of the four most important persons involved in the early development of the Commission, the leadership core mentioned earlier, consisting of Cease, Rich, Hollick and Carlson, only Hollick was not a part of and familiar with "local political and administrative circles" and during the first four years of commission operation, Cease and Jerry Tippins, were integral parts of these c1rcles. Thus, the Comission was always involved and represented by these peopie. One of the former commissioners in discussing this role of the staff went as far as to refer to the present Executive Officer, 
Don Carlson, as "Mr. Boundary Commission." 6 By this, he was referring to the fact that when most people in govermment think of the Portland Boundary Commission, they have an image in their mind of Carlson, not the Commission or any comnissioner, including the chairman. Because he serves as an institutional representative of the Commission, it is important that the Executive Officer be able to gauge and accurately reflect the tenor of the Commission and the commissioners report that the current Executive Officer, Carlson, does this very well.

The staff also serves as an extension of the Commission in its role as a processor of proposals. The basic actions performed as a part of this role are the provision of information to initiators of proposals as to the necessary procedures to be followed by the initiator, such as types of initiation, signatures required, information to be filed with the proposal, and provide the initiator with basic information about the actions the Commission will take in acting on the proposal such as the staff study and its criteria and the public hearing process. This very mechanistic process is followed in most of the cases that come before the Commission. From time to time, however, the staff will take a more active role in the process leading up to formal consideracion of the proposal by the Commission.

This more active role consists basically of screening and advising involved parties on their proposals in order to achieve two purposes simultaneously. In the case of a boundary change proposal which contains a provision which in the minds of the staff constitutes a fatal defect, especially if such defect can be remedied without substantially affecting the substance of the proposal, the staff may 
advise the initiator that on the basis of past Commission decisions or policies, the proposal is less likely to be approved than if it were modified slightly. The purpose of this kind of action is not to usurp the Commission but to enhance the likelihood that the proposal will be one which will allow the initiator to achieve his or her purposes and, at the same time, to allow the Commission to achieve its purposes. It is the position of both the staff and the Commission that the public interest is served best in such cases. The ability of the staff to screen proposals is, to some degree, responsible for the approximately 90 per cent approvil rate and the commissioners report great satisfaction with the staff's performance in so doing. The commissioners feel that the public hearing process and other contacts provide them with a check on the staff in this area, especially should an initiator feel they had been treated cavalierly by the staff or that the staff had promised them a decision they could not deliver. When pressed on the subject, it was clear the staff was aware of the sensitive nature of such action in terms of usurpation. It was also clear, however, that the commissioners recognized the sensitivity but also the necessity of such behavior.

Another point of unanimity among the commissioners, past and present, is that while they enjoyed their relationship with one another and with the staff, service on the Commission was hard work, often unpleasant, and there were no rewards other than those which come from within in response to having performed well a necessary public service. The eleven commissioners are not paid for their services. Some members of the Commission served only a short time because they did not enjoy 
the experience and were not willing to give it the time demanded. Others who served only a short time left for a variety of reasons such as apjointment to a planning commission, election to a cormunity college board, moving out of state, and serious illness. Perhaps the single greatest source of complaint is the public hearings which may extend into the "wee hours" of the morning and for most of the members come at the end of a full working day. In spite of these unattractive aspects of service on the Commission, the makeup of the Commission has been very stable. In its nine years of operation, only thirty people have filled the eleven positions.

If the membership of the Commission has been stable, the staff has been even more sô. The present Executive Officer, Don Carlson, has been with the Commission since 1970 when he joined it as an assistant to Phil Hollick, the original Executive Officer and the only member of the staff to leave the Commission. Carlson moved up to his present position when Hollick left and Ken Martin was hired as Carlson's assistant. Both Carlson and Ken Martin had been employed by Rich at the PMSC before coming to the Conmission. Jean Kretzer, secretary, has been in that position since the beginning. There have been no additions to the regularly budgeted staff since the beginning of the Commission but there are presently four and one-half CETA positions on the staff॰* Carlson has obtained a commitment. from the Executive Department that in additional position will be authorized for the staff when the CETA

*The Comprehensive Employment Training Act is a federal program under which the Portland Boundary Commission receives fedel:al funds to employ persons; 3.5 positions are 100 per cent federal funds; one position is 89 per cent federal funds. 
program ends. As mentioned elsewhere, the work load of the staff has increased over the nine years of Commission operation because of concurrent increases in both the number of proposals and the complexity and number of criteria which are factors in the mandatory study and report. The rate of increase in the numbers of proposals appears itself to be increasing at the present time with the number of proposals for any month in 1978 running at about double the 1977 levels. In the first three months of 1978, the Commission took action on sixty-three proposals; in the first three months of 1977, thirty-six. Maintenance of quality has been possible because of the additional staff provided by the CETA funds, the regular staff alone could not have maintained present levels of quality.

Not only has the staff had to adjust to a quantitatively greater work load, but they have also had to develop a competency in a number of subject matter areas in response to the qualitative extensions brought about by the review of sewer and water systems. is the Commission's environment has growm more complex, the staff's responsibilities in maintaining working relations with other units and agencies of government has also increased. The number of people and programs of th which the staff must be familiar has increased greatly over the years. During these years, the staff has borne the responsibility for managing the Commission's state legislative programs as well, and has acted as the public voice of the Commission as an institution. Despite the tremendous increase in the staff work load, no member of the Commission, past or present, expresses any dissatisfaction with the staff with respect to the quantity and quality of the staff reports and recommendations. 
If the political connections and long tenure of the staff have served the Commission well in the political environment, it has also had another effect, the importance of which would be difficult to overestimate: expertise. Both Carlson and Martin have encyclopedic knowledge about land, topographically, geographically, geologically, and proprietarily. They are familiar with developers, contractors, engineers, planners, designers, architects, consulting engineers, roads, streets, pipe locations, land use plans, past use of land, and literally thousands of bits of information which are vital to the task of the Commission. In short, they are extremely familiar with the governmental and private infrastructure which constitutes the Commission's environment. This is a tremendous asset to the Commission and can be considered a function of the length of tenure and the scale of speration. The regional structure of the Cominission contributes greatly to this, since no one could develop such site specific knowledge statewide. The long tenure of the staff has been due in part to the intrinsic quality of the individuals involved and partly a legacy of the original chairmen, Ronald Cease and Jerry Tippins, who created a climate in which a fear of job loss on other than a merit basis was never a factor. The staff may be subject to pressure from the weight of the work load or other factors, but employment insecurity was never a contributor to such pressure. 
FOOTNOTES

1. Persons interviewed specifically for this chapter include: Richard Brown, Private interview via telephone, Portland, May 23, 1978. John Crawford, Private interview via telephone, Portland, May 30 , 1978. Marilyn Gunsul, Private interview via telephone, Portland, May 22, 1978. Lewis C. Lavachek, Private interview, Portland, May 26, 1978. Dr. Paul J. Slominski, Private interview via telephone, Portland, May 24, 1978. Dr. Ronald C. Cease, Private interview, Portland, July 25, 1978. Jerry Tippins, Private interview vi.a telephone, Portland, May 23, 1978. Carolyn Gassoway, Private interview, Portland, May 25, 1978. Anthony Federici, Private interview, Portland, May 30, 1978. Robert Ball, Private interview via telephone, Portland, May 23, 1978. Kieth Lindahl, Private interview via telephone, Portland, May 30, 1978. Joe Voboril, Private interview via telephone, Portland, May 19, 1978. Marie Williams, Private interview via telephone, Portland, May 22, 1978. Peter McDonald, Private Interview via telephone, Portland and Wilsonville, May 26, 1978. Kenneth Jernstedt, Private interview, Portland, June 1, 1978. A. McKay Rich, Private interview, Portland, July 25, 1978. Ken Martin, Private interview, Portland, April 26, 1978, Don Carlson, Private intervies, Portland, March 13, 1978. See Appendix p. 242 for a list of topics discussed with each person.

2. Jerry Tippins, Private interview via telephone, Portland, May 23, 1978.

3. Ibid.

4. Fasano vs. Board of County Commissioners of Washington County. 264 OR 574, 548 p. 2d. 23 (1973). Peterson vs. Mayor and Council of the City of Kiamath Falls, 279 OR 249 (1977).

5. Jerry Tippins, Private interview via telephone, Portland, May 23, 1978.

6. Joe Voboril, Private interview via telephone, Portland, May 19, 1978. 


\section{CHAPTER X}

\section{SUMMARY AND CONCLUSIONS}

By the mid-1960s, the literature of state and local government had been long dominated by the "political reform tradition" paradigm. Those who took this approach saw America's metropolitan areas to be in a crisis state and to be suffering from a variety of social, cultural, economic and governmental ills which were making these areas virtually uninhabitable. There were, of course, voices which disagreed with this characterization and saw the condition of the metropolitan areas as the result of the working of a market system in which people were making choices based upon, and in furtherance of, their own values. These "public choice," "polycentric" theorists were not, however, as strong a voice as the "traditional" theorists.

The traditionalists dominated the Iiterature of those national institutions which were specially concerned with the governmental component of the "metropolitan problem" such as the Advisory Commission On Intergovernmental Relations; the Council of State Govermments; and the Committee for Economic Development. Through the 1950s and 1360s, these institutional voices had cried out against the existing pattern of local government organization in the metropolitan areas and had held the pattern responsible in part for the social, cultural, and econornic difficulties which faced America's large cities. This pattern was characterized in the traditional literature as fragmented, overlapping, 
and duplicative, and its greatest failure was seen as the inability of the pattern to provide an "area wide" governmental structure which could deal effectively with the social, cultural, and economic problems which were seen as existing "area wide" and amenable only to "area wide" solutions which could only be developed and implemented by a concomitantly "area wide" governmental structure. Throughout the era these institutions had placed the primary responsibility for taking remedial action upon the states. Local governments were not considered capable of reforming themselves and it was beyond the authority and ability of the federal government to act directly. A number of specific actions were recommended to the states including the revision of incorporation and annexation statutes to make it less difficult for the central cities to expand toward an area wide jurisdiction. Another suggestion was that the states establish boundary review agencies which could implement state policies on local government.

A number of studies of Oregon's metropoliton areas were performed by interim committees of the State legislature, the Bureau of Governmental Research at the University of Oregon; the Urban Studies Center at Portland State University, and others. These studies found the very same problems in Oregon's urban areas. The "traditional" approach also dominated the analysis of Oregon's pattern of local government. These studies recommended to the State legislature a number of changes in the State's statutes regulating incorporation and annexation; these proposed changes were localized versions of the recommendations in the national institutional literature. In two of the early studies carried out by interim committees in 1956 and 1962, the committee staffs sought to get 
the committees to put forward proposals creating boundary review agencies but were not successful. In both cases, however, such a proposal was introduced in the next legislative session independently. Neither passed, but aided in preparing the arena for the more serious attempts which were to follow. One of the legislative proposals of the 1962 interim committee study which was successful in the next session was a bill to create metropolitan study cormissions in the state's metropolitan areas to study and recommend to the legislature proposals dealing with the metropolitan areas. By 1.965, the Portland Metropolitan Study Commission (PMSC) was itself at work on a study of boundary review agencies with the intention of proposing such legislation. Because it was busy with proposals considered more important, the PMSC was not prepared to officially sponsor a boundary review agency bill in the 1967 session. Others, however, were not unprepared and two bills were introduced into the 1967 session; one sponsored by the League of Oregon Cities modeled after the California Local Agency Formation Commissions died early in the session; and another introduced by the House Local Government Committee, much like the bill which eventually passed in 1969, passed the House but died in the Senate. After the 1967 session, the PMSC made a decision to prepare and propose a boundary review bill for the 1969 session.

The PMSC spent the early part of 1968 preparing a proposal in concert with several individuals and the organizations which represent local governments: the League of Oregon Cities, the Bureau at Eugene, municipal law expert Orvil Etter, and Portland State Political Science Professor Ronald Cease, who had worked with a boundary review agency in 
Alaska, and others. Iuring the remaindex of 1968, the MMSC worked with an interim committee on local government which had boundary review agencies as one of its two major areas of investigation. Eventually, a proposal was adopted to present to the 1969 session as an interim committee bill. During the work of the interim committee, the boundary review bill was taken under the wing of a conservative Republican representative who was developing a reputation as one of the legislature's specialists in local government-John W. Anunsen. This proved to be especially valuable to the bill when the 1969 session was organized by the Republicans in the House and by a "conservative coalition" in the Senate. If one of the backers of the bill such as Richard Kennedy or Frank Roberts, who were perceived as liberal Democrats, had been the most visible backers of the bill, it probably would have met a less fortunate fate. After warding off a final attempt by the League of Oregon Cities and others to have the boundary commission's membership consist of elected local government officials, the bill passed both chambers by substantial margins. Nevertheless, very few members of that 1969 legislature really knew anything about what these boundary comnissions would be doing. While Anunsen was the most influential legislator, Cease in his role of expert wi tness, had the greatest nonlegislative influence in gaining the bill's passage. He had a great deal of credibility before the relevant comnittees because of his experience in Alaska. Indeed, he may well have been the only person in the state in 1969 with first-hand experience with a boundary commission operation. Cease was subsequently appointed to the original membership of the Portland Commission where he became quite 
influential, initially as the Commission's first chatrman and then as a regular member.

The decision to staff independently and not contract with the Columbia Region Association of Governments or any other organization for staff services was crucial, mainly because it made it possible for the Commission to play the role of an independent, objective, thirdparty in contested cases. At that time it was believed the Comnission's staff would be such an integral part of the operation that the use of another institution's staff would bind the institutions together as well and that this would not be desirable. The selection of Phil Hollick as the first Executive Director in combination with Chairman Cease served to get the Cormission started off on the right foot and to establish important precedents. The Portland Commission was fortunate to obtain and develop good staff and effective leadership through its early formative years.

In the first three legislative sessions following the creation of the boundary commissions, the Boundary Commission Law was amended in two important aspects. In 1971, the Law was changed to give the commissions power to consolidate special districts without a vote. In 1973, the Law was amended to give the commissions authority to review the establishment of comnunity water and sewer systems and the extraterritorial extension of city or district water and sewer lines in order that the commissions be more effective in applying land use planning criteria to boundary changes. Attempts to increase the "real" budget of the Portland Commission were not successful however, and each session the staff felt fortunate simply to obtain two more years of status quo budget. 
One of the more interesting aspects of a new governmental institution is the examination of the way in which it has woven its way into the web of government. Many of the relationships which the Portland Commission has with other agencies and units of government are established specifically by the Law itself. Many others, however, have evolved during the operation of the Commission and are a result of the functions the Commission performs and the way it operates. The totality of the Comission's intergovernmental relations can be divided at the highest level of generalization into two broad categories: input and output. Input relationships are those in which other agencies and units of government provide resources to the Commission which are necessary to its function. This general class is further divided into four types of resources: legislative, technical, administrative and policy. Output relationships are those in which the Commission substantially affects the operation of other agencies and units of government. Output relationships can be usefully grouped into three basic types.

"Direct" relationships are defined and mandated by the Boundary Commission Lar itseif. The Law mandates a direct bilateral relationship between the Commission and others desiring to undertake a boundary change which falls within the Commission's legal jurisdiction. In addition to these direct relationships, the Commission engages in "secondary" relationships which are defined by the effect of the boundary change rather than the type of boundary change. To illustrate: if the City of Gresham wishes to annex unincorporsted territory, it must engage in a "direct" relationship with the Commission according to the 
mandates of the Law. If Rural Fire Protection District No. 10 feels itself to be damage: $y$ the effects of such an annexation, it may oppose the annexation by engaging in a "secondary" relationship with the Commission. Conflict between the City and the District gives rise to the "intermediary" relationships of the Commission in which it usually acts as a catalyst to bring about desired reactions between contending parties. From time to time the Commission is forced to take more aggressive action in bringing about solutions to conflicts among other parties.

If there had been no extension of commission authority, the number of proposals coming before the Commission would have been nearly constant over the first eight years of Commission operation. The addition of sewer and water review functions in 1973 resulted in an approximate one-third increase in the number of proposals. Equally, if not more importantly, in terms of Commission and staff work load, has been the increase in the complexity and sophistication of the staff studies for each proposal and the resulting demands on Commission resources. The Commission approves about ninety per cent of the proposals which come before it, but this figure is inflated by the number of consent annexations which are included within it. The approval rate for controversial cases is lower. Also contributing to this high approval rate is a staff which attempts to assist people in presenting to the Comission proposals which the Commission will be inclined to approve.

An examination of the Commission's decisions reveals definite policy and behavior patterms. The Commission operates within a universe 
of policy. At the highest level are a set of seven goals established by the State and set within the Boundary Commission Law and elsewhere. Next are a set of State implementation actions which include the establishment of a set of boundary commissions to pursue the State goals through the application of State defined criteria to boundary changes. Following these two levels of State defined policies are a set of policies followed by the Commission which create four basic patterns: a structural hierarchy; a planning hierarchy; a public services hierarchy; and a set of operational policies.

In the 1977 legislative session, the boundary commissions faced the most formidable political challenge in their history. In some quarters the action of the legislature was interpreted as a rejection by the legislature of the commissions. However, close examination disproves this interpretation. The boundary comissions were caught up like pawns in a larger game during the session. A small group of conservative Democrats in the House, known as the "Hornets," led by the late Representative Dick Magruder from Columbia County, developed a coalition through tradeoffs which had the strength to hold up the commissions budgets until a bill removing Columbia County from the Portland Commission's jurisdiction was passed. The elimination of the commissions as institutions, on the basis of rejecting their functions, was never a serious possibility in the 1977 session. While denying the conventional interpretation of the actions of the 1977 session, the events do raise questions about the political vulnerability of the commissions.

The commissions are found to be extraordinarily vulnerable because 
they are invisible to most legislators: do not serve the entire state; and most Importantly, do not have a politically effective clientele to further their interests in the legislature. These factors are in addition to opposition based upon a philosophical opposition to state regulation of local government boundary changes. An examination of the work of the Task Force On Boundary Commissions and Annexations supports these notions. There is very little indication of institutional opposition to the commissions but clear evidence of opposition from rural cities and unincorporated areas in northern Columbia County and western Lane County and from small water districts and large fire districts in Multnomah and Clackamas counties because of the Commissions "pro-city" policies. Unquestionably, the report oi' the Task Force constitutes a victory for the commissions in the first round of a promised legislative battle in the 1979 session.

One of the factors which had a substantial impact on the development of the Portland Commission was the existence of a traditionallyoriented, like-minded, "leadership core" which had excellent training and experience and led the Commission through the uncharted waters of the early Commission's course. Most of the policies and procedures established in the early days by this leadership core remain in place today. One of the traditions started by the early leadership was a spirit of camaraderie among the commissioners which has never flagged. The divisions which did exist within the Commission did not cut deeply, and philosophical divisions never carried over to a personal level. The effect of the divisions was also mitigated by the fact that the primary business of the early Commission was to deal with questions of 
governmental structure which did not raise the kind of issues on which the "conservative-business" and "liberal-environmental" philosophic factions would differ. These divisions have changed over time. The "conservative-business" faction has declined in numbers while at the same time the Commission's focus has shifted more toward land use questions. The "liberal-environmentalists" have themselves divided around the new land use focus with the division occurring between those who apply land use criteria intensely and those who apply such criteria more flexibly. The division has shifted from a basis "in kind" to a basis "in degree." The new division is no more intense than that in the past and does not pose much of a threat to the unity or conviviality of the Commission.

Perceptions of the comnissioners about the functions and operations of the Commission have also shifted over time. Commissioners feel that the proposals, problems, and issues the Commission faces have become more complex. They feel the working environment of the Commission has become more bureaucratic and routine and that personal judgment is not as important as it once was. Mechanistic calculation has, to a considerable extent, replaced informed judgment. The commissioners' perceptions of "opinion leaders" on the Commission dovetails with the divisional shift and the perception of increasing formalism and legalism. The lawyers on the Commission are becoming more influential and those whose expertise is recognized as "political" are becoming less influential. Nevertheless, no one on the Commission, past or present, is of the opinion that any one or a few commissioners ever ran the Commission and no commissioner reports ever feeling himself or herself 
to be, $O F$ expected to be, anything less than a fully functioning member of the Comission.

The commissioners have always been satisfied with the quality of the work performed by the staff. The staff is basically self-regulating and very little oversight is exercised over the staff by the Chairman of the Commission who by virtue of that position is expected to direct the staff. The commissioners are also very happy with the work of the staff in its role of representing the Commission in its relationships with other agencies and units of government. The long tenure of the staff members has made it possible for them to develop extraordinary expertise in their job, including an intimate knowledge of the physical features of the territory within the Commission's jurisdiction. Repeated probing revealed no significant sense of dissatisfaction with the staff on the part of the commissioners. Such probing al so revealed no evidence that the staff dominates the Commission. While the Commission most often agrees with the staff's recommendation on proposals, those proposals which are controversial often find the Commission adopting final orders which are in conflict with the staff recommendation. Commissioners are very outspoken on this issue and adamantly insist they are not excessively dependent upon the staff. Their independence is made possible by the availability of alternative sources of information and analysis, and the public hearings which expose the staff-provided information and analysis to public scrutiny. Equally important is the expertise and sophistication of the commissioners themselves, many of whom have training and experience in dealing with both the substantive issues the Commission considers and 
the public forum in which it is carried out. The pervasive feelings of trust and confidence between the staff and the Commission aid the function of the staff in representing the Commission to others. The commissioners are of the opinion that the staff does a good job in acting as an extension of the Commission in both assisting those who come before the Commission, such as in the preparation of petitions, and representing the Commission with CRAG, LCDC, city and county planning and public works agencies, and other institutions.

The Portland Boundary Commission has operated as if under a political cloud since its inception. One of its major problems has been that it has operated in a "catch 22 " atmosphere where it was "damned if it did and damned if it didn't." The Commission seems to have operated on the basis that the political base in the State legislature was not sufficient to support the Commission should it utilize the law vigorously. On the one hand, the Commission has from time to time been chastised by its supporters for not being aggressive enough and told to move faster. The budget footnote of 1971 is such an example. On the other hand, the Commission has operated in some areas with great restraint because it feared controversy might ignite political opposition with which its "firemen" would not be able to cope. North Clackamas County unification and recent cases in Columbia County are examples of this kind of behavior. Each legislative session the Commission has gone to the legislature "hat in hand," attempting to gain additional resources, but has felt satisfied merely to escape with its existing budget. The Comnission's legislative proponents have usually been able to secure legislation affecting its jurisdiction and 
authority but they have never been strong enough to obtain additional money. When for the first time in the 1977 session, the commissions faced a small group of intense opponents, the limitations of its "low profile" strategy became quite apparent. These intense opponents were nearly able to kill the commissions by defeating their budget appropriations because the commissions did not have widespread support. Thus, it appears that the political strategy of maintaining the small group of supporters by being aggressive enough to keep their loyalty, while at the same time attempting to be nonvisible and trying not to arouse controversy or opposition, was a no-growth strategy which ultimately proved to be an inadequate defensive strategy also.

Based upon the history of the Boundary Commission Law, the Commission had every reason to be politically insecure in the early period because the support for the commissions was very Iimited, and widespread knowledge of what they would do might have prevented their coming into existence. However, in the eight years between the 1969 and 1977 sessions, this does not appear to have changed very much. In the 1977 session, as in the 1969 session, very few legislators knew anything about the boundary commissions; and rather than protecting them from harm, this invisibility nearly led to their demise. In order to avoid a repeat of this situation, it is going to be necessary for the Portland Boundary Commission to "go public," to make itself visible to the general public and to public officials, and to defend its existence squarely on the basis of serving the "public interest." If the Boundary Commission is convinced that it performs a necessary function and performs it well, it must attempt to justify its existence 
on that basis to the electorate. The structure and function of the Commission make it very difficult to create the kind of "politically active clientele" which many types of comnissions utilize to maintain themselves and offset a lack of general support and public visibility. Because it serves no "special public" in this way, the Commission must look for support from the "public" which it does serve, the "general public," and it can only do this by becoming visible and known to them.

The decision-making process under boundary commission jurisdiction has at least three important qualities which are not found in the boundary change process outside of boundary commission territory. One of these qualities is the role of the Commission as an impartial third party, capable of making informed and objective decisions in situations where the other parties tend to be both parochial and emotional. Another quality is derived from the role of the Commission as an intermediary, where the Comission acts as a catalyst to bring about a reaction that would not occur without the catalyst being present. A third quality which the boundary commission process creates is that of containing secondary effects. While the "impartially" and "intermediary" qualities do have both an "equity" and an "efficacy" component, neither has as much effect upon efficiency as does the containment of secondary effects. While subject perhaps to diminishing returns, information is an essential ingredient in the decision-making process and it is reasonable to assume that the greater the scope and depth of information available, the more efficient the decision. Thus, a decision-making process that mandates the inclusion of secondary effects into the decision-making calculus will be an inherently better 
process than one which does not include such effects. Even the most rigorously applied cost-benefit analysis will yield faulty conclusions if the cost and benefit spillovers are not included in the equation. The incorporation of secondary effects into the decision-making process also has an equity component because it serves to expand the decisionmaking arena to include all affected interests. Thus, it avoids situations in which a third party suffers from the effects of choices made bilaterally by two directly involved parties. In sumary, the inclusion of secondary effects into the decision-making process serves to heighten both the efficiency and equity of boundary change decisions. The use of a boundary commission to provide an area-wide, regional, comprehensive approach to boundary change decisions in lieu of an expansion of the size of local govermment itself, such as a grand consolidation of all units of government in the region, provides many of the decision making efficiency advantages sought by the "consolidationist" advocates without incurring tha production inefficiencies abhorred by the "polycentrists."

One of the major structural questions faced early in the process of developing the original law was the question of whether the commissions would be on a county, regional, or state-wide scale. Most of the participants supported the concept of regional, multi-county commissions in the three major metropolitan areas of the state. This decision has resulted in the development of three separate commissions operating under the same statutes, but tailoring their operation to meet the unique circumstances of their jurisdictions. Regionalism has affected all of the commissions similarly in some respects and quite 
differently in others.

All of the comnissions have benefited from their regional scope because it has been possible to develop great expertise and familiarity with jurisdictions on this scale. This is true of both the commissioners and the staff. The Portland Boundary Commission deals with boundary changes on a very minute scale, often on a single lot, and operation on this level of specificity would be very difficult for a commission or staff which had responsibility for the entire State. On the other hand, the regional scale provides an area-wide point of view which might not have existed had the commissions been organized on a smaller scale, such as on a county basis as would have been the case under H.B. 1497 (1967) patterned after the California Local agency Formation Commissions.

Another component of the original decision has had some unfortunate effects upon the commissions. The decision not to create boundary commissions in all areas of the state by mandate, but to allow their creation in areas not mandated, has created problems for the existing commissions. While there may have been many reasons why those people involved at the time did not push for state-wide coverage, including the lack of a demonstrable "metropolitan problem" in the areas not covered, one of the most important reasons was to avoid opposition from legislators in the rural parts of the State outside the Willamette Valley. While this may have avoided their opposition, it also negated the possibility of garnering their support. Those legislators from those districts not served by boundary commissions have no direct stake in their welfare. Al though this presents no threat to their legal 
jurisdiction or authority, it does present a threat to their budgets and it makes them subject to attacks on their functions, masquerading as economy measures. Those legislators whose districts are not served by boundary commissions are hesitant to support state funding of agencies which do not operate statewide and from which they perceive no direct benefit. These people are very susceptible to tradeoffs with those who oppose the commissions on a functional basis to form coalitions capable of killing the commissions' appropriations bills. This difficulty could be avoided by extending coverage statewide by region.

Ihe regionalization of the entire state would also provide a solution to another problem created by the original choices: the drawing of jurisdictional boundaries contiguous with county boundaries. In both the Portland and Eugene areas, this has created unnecessary difficulties. Both of these commissions have cities and unincorporated rural areas located at considerable distances from the central cities of the commission's jurisdictions. These areas have long-standing antagonisms toward these central cities and object to having what they consider local matters under the control of a commission which is not only distant, but located in the bastion of evil. Much of this opposition could be mitigated by establishing regional commissions statewide and shifting these areas to a region more reflective of their rural character. The recommendations of the Task Force incorporate this idea by raising the possibility of Oregon coastal commissions which would encompass northerm Columbia County and western Lane County. Such a solution would continue to supply to such areas what the Portland 
Commission termed "preventive medicine." This "medicine," while distasteful, prevents the onset of the "metropolitan problem." While this would be difficult to deny, it is not necessary that the patient dislike and distrust the doctor. Perhaps, to carry on their metaphor, having such "medicine" administered by a rural oriented comnission would be more like taking bad tasting medicine from one's mother. Even though taking it from her did not make it taste any better, it did make it easier to swallow.

One of the patterns that emerges from the examination of the policies followed by the Portland Commission and from discussions about the Commission's operations with commissioners, is that the focus of the Commission in its early days was on governmental structure and the need to prevent further fragmentation and remedy to some extent that which had already occurred. This has remained a concern of the Commission but it is relatively less important than it once was because the role of the Commission as an implementor of land use policy and planning has expanded greatly. While the proportion of cases in which land use is the critical factor is still less than a majority, most large-scale, controversial proposals are so because of their land use implications rather than their structural or governmental implications. With the development of "urban growth boundaries" and the decision by LCDC that all territories within the "urban growth boundaries" are urbanizable, the focus of the Commission may soon be shifting again. The existence of the "urban growth boundaries" and their approval by LCDC will lighten the burden of cases in which the Commission must review the conversion of land to urban use for 
conformance to ICDC Goals and Guidelines. Once authorized to urbanize territory within the "urban growth boundaries," there is likely to be an "annexation rush" to capture as much of the urbanizable territory as possible as a service territory. This is likely to make the allocation of service territories to existing units of government of territory within the "urban growth boundary" a major function of the Commission in the future. Thus, the future may bring the process full circle to a renewed focus on governmental structure and service provision.

If one assumes that the Portland Boundary Commission was created to both prevent the growth of the "metropolitan problem" and remedy that which had already occurred, it must be judged that it has been much more successful at the former than the latter. To a great extent, this is a result of the Boundary Commission Law itself which gives the commissions much greater authority to prevent fragmentation, duplication, overlap, illogical boundaries, defensive incorporation and other elements of the "metropolitan problem" than it does to remedy that which has already taken place. One of the provisions in the Law which was intended to provide a tool by which to reform the existing structure of local government was the power to initiate proposals on its own. After a few futile attempts to bring about major reform of the existing system of local government on its own initiative, such as in Errol Heights and north Clackamas County, the Commission has not actively pursued such ends. One of the limiting factors in doing so has been the sheer growth in the number and complexity of proposals initiated outside the Comnission. The Law mandates a study of all 
proposals and this task has consumed all available staff resources. Inis, combined with the realization by the Commission that major projects initiated by the Commission would require a large amount of staff work in the study and development of the proposals as well as the necessity of building local political support in the affected areas, effectively negates the legal power to initiate such proposals. The iratuility of the Commission to obtain additional staff has been an effective Iimitation on the Commission's ability to develop, initiate, and put into operation, major remedial proposals. The attempt to unify special districts in north Clackamas County is a case where the Commission had the formal legal powei to carry out its mission but retreated in the face of a very strong public opposition. This best demonstrates the lessor ability of the Commission to take remedial action because the elimination of single purpose special districts may well be the clearest part of the Commission's legislative mandate and where it could act most strongly with the greatest possibility of legislative support for its action. This is not to criticize the Commission or the staff for a lack of courage. In fact, their reading of the situation in north Clackamas County was a good one and no one would approve the Commission achieving reform over the prostrate bodies of the local residents or expect the legislature to approve of such action. What it is intended to point out is that the Boundary Commission Law and the funding of the Portland Boundary Commission have created a situation wherein the Commission can operate effectively to prevent the extension of the "metropolitian problam" but not effectively to take remedial action. 
Another contributing factor is that in political terms, it is nearly always more difficult to change the status quo than to retain it. The Boundary Commission Law and the political environment of the Commission add to the inertia of the local governmental system and therefore make it most effective in preventing changes viewed as negative and less effective in creating changes viewed as positive. This being the case, if one concludes that the Commission's most effective role has been in preventing the further development of problems that were developing at the time of its creation, then the value of the Commission in meeting the needs of the people of Oregon is largely a function of the evaluation of the status quo and the direction of change at the time of the Commission's inception. If the condition of the area within the Portland Commission's jurisdiction had been considered disasterous in 1969, then one might we?l have to judge a "nonremedial" commission a failure. If one judged the situation in 1969 as basically good but heading in the wrong direction, then the Commission has served its purpose. At any rate, being critical of the Conmission because it has not taken extensive remedial action is to attack a "straw man." The Boundary Commission Law did not provide for such action and the political environment in which the Comnission has operated would not have supported it, Perhaps the most fortunate aspect of all this is that the Commission was created in 1969, before the status quo became any worse. This may, in fact, be the ultimate justification for getting the legislation in through the back door in the first place; that it would prevent the current situation from worsening during the period of time it would take to build a base of 
public political support.

At the present time, as noted in Chapter VIII, the Portland Commission faces institutional opposition coming from two basic sources. One of these sources is the cities and unincorporated territory in the mural areas of the district which lie at considerable distances from the central city. The other source of opposition to the Portland Commission is the large mural fire protection districts and small water districts. The opposition from the small water districts is unavoidable in the face of a policy to encourage the growth of existing cities to serve urbanizing areas currently served by the small water districts. There is probably no way that the interests of the small water districts and the Commission can be served simultaneously. Large fire districts, on the other hand, are a different matter.

The Commission has in the past encouraged the growth of single purpose fire districts, through annexation and consolidation, on the basis that fire service by a single purpose district is better than no service at all and that fire service by a large, consolidated, single purpose district is better than a multiplicity of small single purpose fire districts. In doing this, however, they have created a problem. Because the present law automatically removes territory annexed to a city from a fire district unless the city is served by the district, these large consolidated fire districts are very much opposed to the Commission's policy of favoring service provision by general units of government. This policy encourages annexation of urbanizing territory to cities, which, in turn, reduces the service territory of the fire district. In many cases where the Commission has encouraged the 
consolidation of fire districts and annexation to existing fire districts, rather than creation of an additional district, it has taken such action for the purpose of increasing the quality and economic efficiency of the district's operation. In some cases, such as District No. 10 in Multnomah County, the Commission has succeeded to the point where it is often difficult for an annexing city to demonstrate that it will provide equal or better fire service than the fire district. Nevertheless, the fire districts are of the opinion that removal of portions of their service territories through annexation will cause a reduction in service quality in toth the annexing area and in the remaining service area. The district point of view is that in such annexations, the Commission may be improving the fise protection of no one while impairing the fire service to everyone. If so, then the Commission would seem to be giving with one hand, by encouraging annexations to and consolidation of single purpose fire districts; and taking away with the other by declaring cities to be the "logical providers of urban services," including fire service, and encouraging annexation to cities which causes automatic withdrawal from the fire districts.

While this course of action may be perfectly consistent from the Commission's point of view, in that both courses of action, given the assumptions, serve the same general purposes of maximizing the quantity and quality of service, reducing fragmentation, and eliminating special districts, from the point of view of the large, consolidated fire districts, it seems very inconsistent and unfair. The very size of the consolidated districts makes them better able to pursue their point of view into the political arena for legislative relief as is demonstrated 
by Final Policy Statement No. 26 of the Task Force which proposes that: "a study of alternative ways to limit the impact of annexation upon special service districts be underiaken." Thus, even on political grounds, the Comnission ought not to treat the large consolidated special districts the same way they might the small special districts. This problem is likely to be exacerbated should the prophesied "annexation rush" to fill in the "urban growth boundaries" take place. The examination of the internal operation of the Portland Boundary Commission leads to the conclusion that the major kinds of problems that one might expect to find, do not exist. Given a parttime lay, unpaid comission and a full-time professional staff, one might reasonably expect the staff to dominate the commission. A facile examination of the frequency of concurrence between staff recommendations and commission decisions might even lend credence to such suspicions because the Commission's decisions most of ten concur with the staff recomnendations and the Commission ofte:l uses the language of the "Staff Report" as official reasons for its actions as required by the Law. To assume from this that the Commission is the "tail" on the staff "donkey" would be a mistake. The Cormission and the staff usually are in agreement because the "fact situation" and the general. policies of the Conmission usually lead to a clear conclusion, especially in the majority of boundary changes which are not controversial. To assume staff domination on the basis of agreement on a multitude of small parcel consent annexations to the City of Portland would be foolish. In those cases where the "fact situation" and the application of policy to it, do not lead inexorably to a conclusion, 
but instead require the application of informed judgment, the staff and the Commission often come to different conclusions. One could ascribe this independence of judgment to a number of factors but the following seem to be the most important.

To begin with, the Commission is lay but not very lay. Many members have come to the Comnission with considerable experience in the area of land use which provides them considerable substantive knowledge of one of the major areas of Commission concern as well as providing them with experience in the kind of public form in which the Commission operates. Those commissioners who have served on city or county planning commissions before joining the Boundary Commission have been so advantaged. Others have been practicing lawyers whose profession prepares them well for service on the Commission. This is also true of commissioners who have been college professors and newspaper editors. In short, the membership of the Commission has been lay, but it has not consisted of persons whose lack of intelligence, expertise, training, education, or any other individual characteristics would make them vulnerable to dominance by a high quality professional staff.

Not only are the commissioners not particularly dependent upon the staff because of a lack of general information about the Commission's operation or because of individual weaknesses, the Commission is also not solely dependent upon the staff for information on specific cases. The Commission has easy access to other sources of information and analysis through the public hearing process. A poor quality study or any attempt to deliberately misinform the Commission 
or to fabricate a "fact situation" could and would be quickly unmasked by the public hearing process whereby anyone suffering from such behavior would have ample opportunity to dispute the staff-supplied information and analysis publicly and he or she would not have to hire a lawyer to do it.

These two factors: the independent personal resources of the commissioners and the presence of alternative sources of information and expertise; and the public presentacion and examination of the staff information and analysis, explain the heal thy and honest relationship between this part-time, lay commission and its full-time professional staff.

The extent to which many of the commissioners seem unaware of the political threats to the Commission comes as a surprise. Any well informed observer, if asked to discuss the major problem facing the Commission, would at any time in the history of the Commission have discussed the political difficulties of the Commission and the consequent threat to its budget. Many commissioners, however, seem quite unaware of this and when asked to discuss what they consider to be the major threat to the Commission choose an entirely different subject.

The subject most often chosen is a perceived threat that the Commission's operation will be caught up in a web of legality and forced to abandon what the commissioners see as an informal, relaxed, low-key method of operation where "John Q" can come and make his case to the Commission on his owm; a "people's court." Many commissioners pointed out that lay persons are usually assigned greater credibility 
by the comnissioners than lawyers, and would be well advised to represent themselves before the Commission. Not a single commissioner, past or present, including the lawyers wants this system to be supplanted by a more formal or legalistic method of operation. There have been critics of the Commission such as Diane Spies, who have advocated a more formal process including such features as subpoena powers, direct cross examination, rules of evidence, and challenges, but these voices have never had much of a following. Now, however, the pressure for such a change is coming from the courts. In a recent decision, League of Women Voters of Central Lane County vs. Lane County Local Government Boundary Commission, ${ }^{1}$ the Oregon Court of Appeals ruled that the legislature had, in a 1973 amendment to Oregon Revised Statute (ORS) 34.040 , repealed by implication ORS 199.461(3). ORS 199.461(3) had provided that original jurisdiction over Boundary Commission decisions lay with the circuit courts under the writ of review. Now, the original jurisdiction over Boundary Commission decisions is before the Court of Appeals under the Administrative Procedure Act (APA), ORS 183.310-183.500. The effect of the decision was to place the boundary commissions under the APA, which requires those agencies operating under its provisions to operate in a much more formal and legalistic manner than the way the Portland Commission has been operating. Under the APA, the Commission would have to follow extensive procedures in the rule-making process, ${ }^{2}$ and the Commission's procedures would have to include provisions for subpoenas, ${ }^{3}$ cross-examination, ${ }^{4}$ oaths, ${ }^{5}$ verbatim record, ${ }^{6}$ and other mandated procedures. In order to avoid such requirements, the 
Commission will have to obtain an exemption from inclusion under the APA, as is provided for some agencies in the APA statute. ${ }^{7}$ This must be a high priority item for the Commission in the next legislative session and the current Chairman, Robert Ball, intends to pursue it vigorously. Several of the current commissioners feel so strongly about the current method of operation that should the Commission remain under the APA and be required to formalize and legalize its procedures, they would seriously consider resigning from the Commission. While the Boundary Commission Law was firmly grounded upon the political reform tradition and was aimed at the attainment of a pattern of local government which could be characterized as consolidationist, the Portland Boundary Commission in its operation and the qualities which the Commission boundary change process contains; independent third party analysis; containment of secondary effects; and intermediary action, are qualities which can appeal to proponents of both the traditional and public-choice paradigms. The perception that these qualities enhance both the equity and efficiency of the boundary change process is not a function of the acceptance of the set of assumptions of either theoretical approach. 


\section{FOOTNOTES}

1. 32 Or. App. 53 (1978).

2. ORS 183.335. ORS 183.410.

3. ORS 183.425. ORS 183.440.

4. ORS 183.450(3).

5. ORS 183.415(6).

6. ORS 183.415(8).

7. ORS 183.315. ORS 183.317. 


\section{SELECTED BIBLIOGRAPHY}

Advisory Commission on Intergovernmental Relations. Alternative Approaches to Govermmental Reorganization in Metropolitan Areas. Washington, D.C.: Government Printing Office, 1962.

Advisory Commission on Intergovernmental Relations. Governmental Structure, Organization and Planning in Metropolitan Areas. Washington, D.C.: Government Printing Office, 1961.

Advisory Commission on Intergovernmental Relations. Performance of Urban Functions: Local and Area-Wide. Washington, D.C.: Govermment Printing Office, 1963.

Advisory Commission on Intergovermmental Relations. The Problem of Special Districts in American Government. Washington, D.C.: Government Printing Office, 1964.

Advisory Comnission on Intergovernmental Relations. State Constitutional and Statitom Restrictions Upon the Structural, Functional, and Personnel Powers of Local Government. Washington, D.C.: Government Printing Office, 1962.

Advisory Commission on Intergovernmental Relations. State Legislative Program. Washington, D.C.: Government Printing Office, 19631967.

Anunsen, John W. Private interview via telephone. Portland and Salem. January 17, 1978.

Anunsen, John W. Private interview via telephone. Portland and Salem. March 1, 1978.

Balderson, Lyle E. Letter from Lyle E. Balderson, Area Development Director, CHAG, to Portland Boundary Commission. December 10, 1973. Portland. Portland Boundary Commission files.

Baldwin, Robert S. Letter from Robert S. Baldwin, Planning Director, Multnomah County, to the Portland Boundary Commission. December 17, 1973. Portland. Portland Boundary Commission files.

Ball, Robert. Conmissioner. Private interview via telephone. Portland. May 23, 1978.

Bateson, Cornelius. Private interview via telephone. Portland and Salem. January 20, 1978. 
Berkley, George E. and Fox, Douglas M. 80,000 Governments: The Politics of Subnational America. Boston, Mass.: Allyn and Bacon, Inc., 1978.

Bish, Robert I. The Public Economy of Metropolitan Areas. Chicago, III: Werkham, 1971.

Bollens, John C. and Schmandt, Henry J. The Metropolis. New York: Harper and Row, 1965.

Brown, Richard. Commissioner. Private interview via telephone. Portland. May 23, 1978.

Carlson, Don. Letter from Don Carlson to îlen Otto, Chairman, House Committee on Local Govermment and Urban Affairs. March 18, 1975. Portland. Portland Boundary Commission files.

Carlson, Don. Letter from Don Carlson to Kieth Burns, Chairman of the Senate Local Government Affairs Committee, "Legislation Affecting Boundary Comissions," May 14, 1973. Portland. Portland Boundary Commission files.

Carlson, Don. Private interview. Portland. March 13, 1978.

Carlson, Don. Private interview. Portland. March 20, 1978.

Carlson, Don. Private interview. Portland. April 4, 1978.

Cease, Ronald C. and Saroff, Jerome R. The Metropolitan Experience in Alaska. New York: Praeger, 1968.

Cease, Ronald C. A Report on State and Provincial Boundary Review Boards. Portland: The Portland Metropolitan Study Commission, 1968.

lease, Ronald C. Private interview. Portland. July 25, 1978.

Cease, Ronald C. Private interview. Portland. August 4, 1978.

Center for Yopulation Research and Census. Population Estimates, Oregon Counties and Incorporated Cities. Center for Population Research and Census, Portland State University, Portland, Oregon.

Central Lane Planning Council. "Minutes Boundary Review Board Meeting," December 4, 1968. Salem. Oregon State Archives.

Clackamas County Fire District No. 1. Letter from Clackamas County Fire District No. I to Task Force on Boundary Commissions and Annexation. January 12, 1978. Salem. Task Force files. 
Clark, Edward I. Letter from Edward L. Clark, Chairman, Salem Boundary Commission; to Ronald C. Cease, Chairman, Portland Boundary Commission. September 18, 1969. Portland Boundary Commission files.

Columbia County Board of Commissioners. Letter from Columbia County Board of Commissioners to Task Force on Boundary Commissions and Annexations. December 14, 1977. Salem. Task Force files.

Columbia Region Association of Govermments. Memorandum to Don Carlson concerming GRAG review of proposed boundary changes. September 10, 1973, Portland. Portland Boundary Commission files.

Committee for Economic Development. Modernizing Local Government. Washington, D.C., 1966.

Common Council of Florence, The. Letter from the Common Council of Florence to the Task Force on Boundary Commissions and Annexations. January 23, 1978. Salem. Task Force files.

Council of State Governments, The. The States and the Metropolitan Problem. Chicago: The Council of State Governments, 1956.

Council of State Governments, The. Suggested State Legislation. Chicago: The Council of State Govermments, 1967.

Crawford, John. Commissioner. Private interview via telephone. Portland. May 30, 2978.

Crescenzi, Jack R. Letter from Jack R. Crescenzi, Fire Chief, Beaver Creek Rural Fire Protection District to Task Force on Boundary Comnissions and Annexations. January 18, 1978. Salem. Task Force files.

Daniel, Mann, Johnson \& Mendenhall. Implications of Government Unification North Glackamas County, Oregon. Portland. Daniel, Mann, Johnson \& Mendenhall, 1973.

Danielson, Michael N. Metropolitan Politics: A Reader. Boston: Iittle Brown, 1966.

Dille, James. Letter from James Dille, Board Chairman, Clackamas Fire District No. 71 to Task Force on Boundary Commissions and Annexations. Febmary 2, 1978. Salem. Task Force files.

Dunes City, Mayor of. Letter from the Mayor of Dunes City to the Task Force on Boundary Commissions and Annexations. January 25, 1978. Salem. Task Force files. 
English, Virgil R. Letter from Virgil R. English, Director, Oregon Fire District Directors Association, to Task Force on Boundary Comissions and Annexations. January 29, 1978. Salem. Task Force files.

Etter, Orval. Private interview via telephone. Portland and Eugene. December 14, 1977.

Federici, Anthony. Commissioner. Private interview. Portland. May 30, 1978.

Gassaway, Carolyn. Letter from Carolyn Gassaway, Chairman, Portland Boundary Commission, to members of the Oregon State Senate. June 2l, 1977.

Gassaway, Carolyn. Commissioner. Private interview. Portland. May 25, 1978.

Greer, Scott. The Emerging City. New York: The Free Press, 1962.

Gulick, Luther H. The Metropolitan Problem and American Ideas. New York: Alfred A. Knopf, 1966.

Gunsul, Marilym. Commissioner. Private interview via telephone. Portland. February 20, 1976.

Gunsul, Marilyn. Commissioner. Private interview via telephone. Portland. May 22, 1978.

Gustafson, Rick. Private interview via telephone. Portland. May 4, 1978.

Jernstedt, Kenneth. Commissioner. Private interview. Portland. June 1, 1978.

Jones, Don. Letter from Don Jones, Executive Secretary, League of Oregon Cities; to Homer Chandler, Director, Columbia Region Association of Governments. December 27, 1968. Oregon State Archives.

Jones, Don. Letter from Don Jones, Executive Secretary, League of Oregon Cities, to Subcomittee No. 1, Joint Committee on ways and Means. May 2, 1969. Oregon State Archives.

Jones, Don. Private interview via telephone. Portland and Salem. Janiary 18, 1978.

Journals and Calendars of the Senate and House, Regular Sessions and Special Sessions 1957-1977. Oregon Legislative Assembly. Salem.

Kennedy, Richard. Private interview via telephone. Portland and Salem. January 5, 1978. 
Kirkpatrick, Corky. Printed statement of Corky Kirkpatrick, Chairman, CRAG Board of Directors, to Task Force on Boundary Commissions and Annexations. January 19, 1978. Salem. Task Force files.

Lavachek, Louis C. Commissioner. Private interview. Portland. May 26, 1978.

Iindahl, Keith. Commissioner. Private interview via telephone. Portland. May 30, 1978.

Iinklater, William. Letter from William Linklater, Assistant Attorney General, to Ronald Cease, Chairman, Portland Boundary Commission, responding to ten questions requesting clarification and interpretation of the law. December 30, 1969. Portland. Portland Boundary Commission files.

Logan, Robert K. Letter from Robert Logan to the author. February 3, 1978.

Long, Norton C. The Polity. Chicago: Rand McNally \& Company, 1962.

McDonald, Peter G. Commissioner. Private interview via telephone. Portland and Wilsonville. May 26, 1978.

McWilliams, Bob. "Reply to Boundary Review Board Staff Report State I, Phase I Annexation." August 22, 1973. Portland. Portland Boundary Commission files.

Magruder, Dick. Private interview via telephone. Portland and Clatskanie. May 4, 1978.

Martin, Ken. Private interview. Portland. April 26, 1978.

Martin, Ken. Private interview. Portland. August 2, 1978.

Norwood, Red. Letter from Red Norwood, Mayor of the City of St. Helens, to the Task Force on Boundary Commissions and Annexations. January 23, 1978. Salem. Task Force files.

Oregon. Constitution.

Oregon Department of Justice. "Opinion No. 7448 ," by James A. Redden, Attorney General. Salem. May 11, 1977.

Oregon, Executive Department. Organization of Oregon State Government. Salem. November, 1977.

Oregon Legislature. Joint Committee on Ways and Means. 1971 Oregon Legislature, Regular Session. "Minutes." Salem. Oregon State Archives. 
Oregon Legislature. Joint Legislative Interim Committee on Local Government. Findings and Recommendations of the Joint Legislative Interim Committee on Local Government. Salem. 1956.

Oregon Legislature. Joint Legislative Interim Comittee on Local Govermment. Metropolitan and Urban Area Problems in Oregon, Report of the Legislature Interim Committee on Local Government. Salem. 1963.

Oregon Legislature. Joint Leglslative Interim Comittee on Local Government. "Minutes." June 7, 1968. Oregon State Archives.

Oregon Legislature. Joint Interim Committee on Local Government. "Minutes of Interim Committee hearing on ICC 192." September 13, 1968. Oregon State Archives.

Oregon Legislature, Senate. Local Govermment Committee. "Minutes." May 13, 1969. Salem. Oregon State Archives.

Oregon. Oregon Laws 1957-1977. Oregon Legislat1ve Assembly. Salem.

Oregon. Revised Statutes.

PIntarich, Stan. Letter from Stan Pintarich, Scappoose City Councilman, to Governor Straub. July 18, 1977. Salem. Task Force files.

Portland Boundary Commission. "Biennial Statistical Summary." March, 1973. Portland. Portland Boundary Commission files.

Portland Boundary Commission. "General Principles and Criteria for Considering a Wide Range of Boundary Change Proposals." March 20, 1970. Portland. Portland Boundary Comission files.

Portland Boundary Cormission. "Instruction for Flling Minor Boundary Change Proposals." Form supplied by Commission to public. Available at Portland Boundary Commission office. 320 S. W. Stark, Portland, Oregon, Room 530.

Portland Boundary Commission. Letter to Representative Glen Otto regarding conflict between Lusted Water District and the City of Gresham. February 16, 1978. Portland. Portland Boundary Commission files.

Portland Boundary Commission. Memorandum to Boundary Commission from Staff." July 9, 1971. Portland. PortIand Boundary Commission files.

Portland Boundary Commission. "Minutes." Portland. July 16, 1969. Portland Boundary Commission files.

Portland Boundary Commission. "Minutes." Portiand. September 10, 1969. Portland Boundary Commission files. 
Portland Boundary Commission. "Policy on Land Use and Coordinated Planning." Nay 20, 1970. Portland. Portland Boundary Commission files.

Portland Boundary Commission. "Proposed Rainier Area Wide Fire Protection System." Staff memorandum to Commission. October 11, 1973. Portland. Portland Boundary Commission files.

Portland Boundary Commission. "Staff Report." Prepared for each proposal before the Commission. Portland. Portland Boundary Commission files.

Portland Boundary Commission. "Suggested Policy on General Purpose Government, Revised." Memorandum from staff to Commission. October 19, 1977. Portland. Portland Boundary Commission files.

Portland General Electric Company. Letter from Portland General Hlectric Company to Portland Boundary Commission. June 7, 1972. Portland. Portland Boundary Commission files.

Portland Metropolitan Study Commission. "Information Miemorandum to Executive Committee from B.R. Committee." August 31: 1965. Salem. Oregon State Archives.

Portland Metropolitan Study Commission. Memorandum of A. McKay Rich to B.R.C." January 19, 1967. Salem. Oregon State Archives.

Portland Metropolitan Study Commission. "Memorandum to Boundary Review Committee from Robert G. Sampson." September 14, 1967. Salern.: Oregon State Archives.

Portland Metropolitan Study Comnission. "Minutes Boundary Review Committee." January 18, 1968. Salem. Oregon State Archives.

Portland Metropolitan Study Commission. Minutes Boundary Review Committee." Febmary 1, 1968. Salem. Oregon State Archives.

Portland Metropolitan Study Commission. IMinutes Boundary Review Comnittee." February 28, 1968. Salem. Oregon State Archives.

Portland Metropolitan Study Commission. "Minutes Boundary Review Committee." April 23, 1968. Salem. Oregon State Archives.

Portland Metropolitan Study Commission. Minutes Boundary Review Committee." May 9, 1968. Salem. Oregon State Archives.

Provost, Joe W. Letter from Joe W. Provost, Fire Chief, Clackamas Fire District No. 71 to Task Force on Boundary Commissions and Annexations. February 2, 1978. Salem. Task Force files.

Rich, A. Mckay. Private interview. Portland. October 2l, 1977. 
Rich, A. McKay. Private interview. Portland. July 25, 1978.

Roberts, Frank. Private interview. Portland. April 7, 1978.

Sandy Fire District No. 72. Letter from Sandy Fire District No. 72 to Task Force on Boundary Commissions and Annexations. January 23, 1978. Salem. Task Force files.

Santee, Robert. Letter from Robert Santee, Administrator, Tigard Water District to Task Force on Boundary Commissions and Annexations. January 19, 1978. Salem. Task Force files.

Seibel, Gene, Letter from Gene Seibel, Assistant Administrator, Wolf Creek Highway Water District to Task Force on Boundary Commissions and Annexations. January 19, 1978. Salem. Task Force files.

Slominski, Dr. Paul J. Commissioner. Private interview via telephone. Portland. May 24, 1978.

Straub, Robert. Veto message, S.B. 1113, from Governor Straub to Secretary of State Norma Paulis. July 26, 1977. Salem. Oregon State Library.

Task Force on Boundary Commissions and Annexations. "Minutes." December 14, 1977. Salem. Task Force files.

Task Force on Boundary Cormissions and Annexations. "Minutes." January 12, 1978. Salem. Task Force files.

Task Force on Boundary Commissions and Annexations. "Minutes." January 19, 1978. Salem. Task Force files.

Task Force on Boundary Commissions and Annexations. "Minutes." January 26, 1978. Salem. Task Force files.

Task Force on Boundary Commissions and Annexations. "Minutes." February 9, 1978. Salem. Task Force files.

Tippins, Jerry. Letter from Jerry Tippins, Chairman, Portland Boundary Commission, to Gresham City Council and Pural Fire Protection District No. 10 Board of Directors. August 28, 1973. Portland. Portland Boundary Commission files.

Tippins, Jerry. Commissioner. Private interview via telephone. Portland. May 23, 1978.

U.3. Bureau of the Census, Statistical Abstract of the United States: 1971. 92d ed. Washington, D.C. 1971.

U.S. Commission on Intergovernmental Relations. Report to the President. Washington, D.C. 1955. 
Vagt, Robert $R$. Letter from Robert $R$. Vagt, Attorney for St. Helens Rural Fire Protection District to Portland Boundary Comission. Portland. Portland Boundary Commission files.

Voboril, Joe. Commissioner. Private interview via telephone. Portland. May 19, 1978.

Wagner, D. F. Letter from D. F. Wagner, Insurance Service Office of Oregon, to Don Carlson. July 7, 1972. Portland. Portland Boundary Commission files.

Wallis, Ray. Letter from Ray Wallis, Secretary-Treasurer, St. Helens Rural Fire Protection District to Portland Boundary Commission. June 30, 1972. Portland. Portland Boundary Commission files.

Weast, Burton. Director, Portland Home Builders Association. Private interview via telephone. Portland. May 5, 1978.

Webster's Seventh New Collegiate Dictionary. Springfield, Mass. G\&C Merriam Company. 1972.

Williams, Marie. Commissioner. Private interview via telephone. Portland. May 22, 1978. 
APPENDIX 
PORTLAND MLTROPOLITAN ARTA LOCUI, GOVFINM!ENT BOUNEARY CO!RIISSION

Febriary 20,1970

To: Boundary Cocinissioners

From: Staff

Subject: STAFF RFPORT ON: Botndary Charge proposal ivo. 98 Annexation of territory to the City of Banks, Washington County - Receivel January 26, 1970

This proposal was intiated by consent petition from the property owner (l"ilitim J. and Cenevicvo H. llerinclix) as provided by ons 222.170 (trjple two thirls annexation $12 w$ ) and nects the requirenents of that statute and Chapter 494 Oregon Laws 1969. As set forth in Section 16a of Chanter 494, if this proposal is approved, the annexatior. tates effect immodiately upon adoption of the final order.

\section{Description of Area.}

The tcrritory to be annexed is situated south of the existing city linits and extends south to the liison River lligliway an 1 cast of the Nolalen state Ilighay-the main north-south arterial cuming through the city. The property contains approximately 100 acres and is vocant.

Reason for Amexition

The rcason given for annexalion by the property owners is to obtain city scrvices, particularly batcr and sever. The proposed use of the preperty, or at least a portion of $i t$, is for the development of a nobile home park. Aprroxiratcly one huncired units are planned for the initial developnent stage.

The amexation proposal apperently stems from an initial discussion with the Wasinington Couricy Planning. Department ir. Which it was indicated that they thouglit the cievelopment proposaj. preriature. Fublic facilitics are not available to the property by way of the councy and, therefore, based on thejr cxisting polj.cy that such services are required: Ghe County plaming stafi indicated their disapproval. The property was zoned F-1 (agricultural) by the County on January 20, 1970 .

Staff discussion With the llayor of Fanks (Ralph Cop) indicated the city did not fecl favorable toward the anncxition becalse of linited capobility of ci.ty selier and water service. The resolution, dated Febzlary 10, 1970 attached to ihis report, confirms our discussion with the mayor that the city js concerned about additional water and scver hookups.

It is our understanding that the legal counsel for the city advised the city councis that the petition for annexation could not be accented or rejected by the Council, but must be "orwarled to the Boundary Conmissjon. The stinf informed tire city through the layor thit if they vishol to express an official opinion on the ennexation r.roposal that they con.. d do so and if such action were iaken, to forward a cony to the joundary Conussion. (Hothing has been received as of this date $-2 / 20 / 70$ ) 
Pequ 2 iproposal औo. of,

Also of significance to this proposal is that the United Sewerage Agency recently fornce in Washingeton County includes the City of Banlis. It is one of several enticies that is not contiguous with the larger district and the extent of its boundaries was limited to the existing city linits. In talking to the Comty Ndministrator it is his foeling and infiression that any annexation to the city should also include anncintion to the United Sclierage Agency District. However, since the District will take over and operate the sciverage plant in Banks, they would want to to the necessiry engineering studies to determine the plant's cajabilities in handling additional connections beforo considering an annexation profosal which includes any substantiai develoyment pians. 
Page 3 (Proposal No. 98)

\section{Recomendation}

Based on information received to date, the staff recomends denial of this proposal on the following grounds:

1) The city's present sever and water facilities are only sufficient to handle additional hookups within the existing city linits.

2) The city has not develoned sufficient studies or plans to enlarge or expand the present water and scwer system to adequately service additional territories.

3) The city has indicated they do not desire additional property being added to the city because of the above mentioned circumstance

4) Any annoxation to the city needs to be coordinated with the county inasmuch as the United Severage Agency will be responsibje for future severoge opcrations in the City of Banks. 
PROPOSAl. NO. 1198 - ClTY OF BANKS - Annexation

$3 / 15 / 78 \mathrm{Hrg}$.

Petitioner: Sunset I. D. Inc. (Brian G. Allen, Pres.)

Date Filed: $2 / 3 / 78$ (90th day: 5/4/78)

Proposal No. 1198 was inftiated by a consent petition of the property owners. The petition meats the requirement for initfation set forth in ORS 199.490 and ORS 222.170 (Triple mujority annexation law). If the Commission approves the proposal the boundary change will become effectlve on the date of approval.

The territory to be annexed is located generally on the south edge of the city, north of th.2 Wilson River liwy., west of the Southern Pacific $R$ aflroad track and east of Nehalcm Valley llwy. 47. The territory contains 7.3 acres, an estimated population of 0 , and is evaluated at $\$ 9,100$.

Reason for Annexation. The property owners desire to obtain urban services to facilitate a commercial development. The tax lot under consideration is split, the westerly 1.28 acres being within the city limits. The petitioner proposes developing the parcel with a bank, a post office, office space and a market.

History. This parcel requested annexation In January 1970 (Proposal No. 98). The request was denied because Banks was opposed on the basis of inadequate services.

Land Use and Planning.

Site Characteristics. The site is relatively flat; elevation is approx. 210 feet. The topographic fearures range in tie 0 to 3 percent category. The site has had all original vegetation removed. It is currently uillized for farming. The owner says he has had "brlow average yields the past several years."

The soils information for the subject site was provided by the USUA Soils Conservation Service. The following information was derived from the SCS soil interpretation sheets and maps.

Aloha silt loam, $0-3$ percent slope. This solls is used for agriculture, recreation, wildlife and homesites. Permeability of this soll is moderate over slow. Runofe is slow to medium and erosion hazard is slight to moderate. There is no frequency of flooding. The depth to bedrock is greater than 60 inches.

The applicant provides the following information:

"Although the subject site is relatively flat, there is sufficient grade to direct water runoff from the site. Surfaces runoff flow into the natural drainage ditch which traverses a north south direction along the eastern border of the stie."

"The subject site is not located within a flood plain area. The flood plain in closest proximity to the subject site is that of the West Fork of Dairy Creck. Its 100-year flood line limit abuts the western edge of the City of Banks Iimits."

"The subject site is only a falr environment sutted to mammal and upland bird habitats due to the close proximity of the site to existing urban development."

C1ty Planning. In 1974 the f1rm of Daniel, Mann, Johnson, \& Mendenhall prepared a comprelicnsive plan for the City of Banks. This plan favored urban expansion to the gouth to the Wilson River Hishway. This firm is again working on a comprehensive plan for the city. The consultant is working with a citizen's committee; a draft of the plan is to be complete by the end of July. December is the city's LCDC compliance date. 
Puge 2 (Proposal No. 1198)

Zoning on the portion of the parcel inside the clty is $R-7$.

County Planning. The county's comprehensive plan designates the stte Natural Resource. Current zoning is GFU-38 - General Farm Use - with 38 acre minimun lot sizes. Growth for Banks in the county plan is provided to the north.

Regional Plinuing. The CRAG Framework Plan designates the territory Urban. Last Thursday, Feb. 23, 1978, the chaG Board of Directors adopted an Interfm urban growth boundary to comply with the LCDC interlocutory order. This 1 ine will not be effective unt 11 approved by LCDC. This review by LCDC is expected March 10. The Interim boundary line as adopted by the CRAG Board is drawn at the present city limits of Banks and excludes the property under consideration.

\section{I,CDC Goals:}

Coals $4,5,6,7,8,9,10,12,13,15,16,17,18$ and 19 do not apply here.

Goal 1 - Citizen Involvement. The Banks-Timber CPO No. 14 was notified of this proposal. No response has been received to date.

Goal 2 - Land Use Planning. The regional and county plans are not in accord. CRAG designates the area Urban whereas the county designates it Natural Resource. The city does not yet have a plan, so we have no knowledge of what use would be consistent with the city.

Goa1 3 - Agricultural Lands. The solls on the stte are prime agricultural according to LCDC criteria. The LCDC annexation rule applies here:

"B. For the annexation of lands not subject to an acknowledged plan the requijement of goal \#3 (agricultural lands) and goal \#14 (urbanization) OAR 660-10-060 shall be considered satisfied only if the clty or local government boundary conmission finds that adequate public facilities and services can be reasonably made avatlable; and:

"(1) The lands are physically developed for urban uses or are within an area physically devejoped for usiuan uses; or.

"(2) The lands are clearly and demonstrably needed for an urban use prior to acknowledgement of the appropriate plan and circumstances exist which make it clear that the lands in question will be within an urban growth boundary when the boundary is adopted in accordance with the goals."

The staff's findings on these criteria follow:

-B. Public services and facllftes can be reasonably made avallable.

--(1) Are the lands or the surrounding lands developed to urban uses?

No. The parcel to the north of the proposal is owned by the Banks School District and is undeveloped. The reminder of the surrounding lands are open and used for farming.

--(2) Are the lands needed for urban use prior to acknowledgement of the plan and is it clear that the territory will be within an urban growth boundary?

No. The BC staff discussed the proposal with the rity's consultant, Rich Carson, on Fcb. 28. He sald he had found that there are 9.6 acres of vacant developable land within the city. of these 9.6 acres, 1.7 are for residential use, 2.4 for comereial use and 5.5 for industrlal use. The consultant said 
Page 3 (Proposal No. 1198)

his profections indicate 3 additional acres of commerclal land will be needed by the year 2000. The $B C$ staff concludes that annexation of this land for conmerclal use would Increase the comercial lands in the city by $80 \%$ in excess of the quantity projected to be needed in the long-range planning.

The fact that the county's land use plan designates the territory Natural Resource and has zoned it GFU-38 makes it questionable if the territory will be fincluded within the Banks urban growth boundary.

Goal 11 - Public Facilitles and Services. See the Facllities \&ervices section of this report.

Goal 14 - Urbantzation. The LCDC rule on annexation is applied under LCDC Goal 3 above.

Fasilities and Services.

Sewer. A new sewage treatment plant was placed into operation within the City of Banks in 1967. The plant is operated by the Unified Sewerage Agency. The treatment plant was designed to serve 1050 people; the current population of Banks is 500 . There is an 8-inch sewer main to the current city limits of the suiject lot. This line can serve all the vicinity down to within 50 feet of the Nehalem Highway.

Water. The City of Banks is served by domestic water obtained from springs. Also the city has completed drilling a well, which will provide adequate water for the foreseeabie future. There is an existing 6-inch water main approx. 200 feet north of the subject site, and a 3-inch lateral to the city limits.

Police. The city has its own police department with a staff of 5 police officers. It is not likely that the proposed development will create a need for the expansion of these services. The property presently receives protection from the county sheriff.

Fire protection. The territory is within the Tri-C1ty RFPD, a 30-man volunteer force. This service will not be alter'd by the annexation.

Findings. Based on its investigation the staff has found that:

1. The territory contains 7.3 acres and is vacant having an estimated evaluation of $\$ 9,100$.

2. The property owner desires urban services to facllitate a comercial development. The site is proposed to be developed in conjunction with 1.28 acres already within the city limits.

3. The site is relatively flat, has had its original vegetative cover removed, has solls composed of Aloha silt loam, class II farmland. The site is currently ut1lized for farming.

4. The city's planing is in process and should be ompleted by December of this year, which is the city's LCDC compliance date.

5. The county comprehenstve plan designates the sile Natural Resource. Current county zon ing is GlU-38.

6. The CRnG plan designates the site Urban. 
Page 4 (Proposil No. 1198)

7. The proposal conflicts with LCDC Coals 3 and 14 as set forth in the l.CDC Annexation Rule because:

(a) There is no demonstration of need to annex this land at this time. There are currently 2.4 acres of land avallable in the c1ty for commercial use, amounting to $44 \%$ of the city's profected need for commerclal land to the year 2000. Addition of this 7.3 acres for commerclal use would be in excess of the long range projected need.

(1) Tr : terrtory is not developed nor is it physically surrounded by development. The Natural Resource designation on t!e sounty plans makes it highly questionable if the territory will be within an urban growth boundary.

8. An 8-inch sewer main, located in Main Street (Nehalem Hwy. \#47) fronts the par cel and is adequate to serve the territory.

9. The property could receive water from the City of Banks through a 6-inch main located approximately 200 feet from the parcel. A 3-1nch lateral line located in Maln St. fronts the property.

10. Police protection is presently provided by the county sheriff. Upon annexation this service would be provided by the City of Banks police department.

11. The territory is within the Tri-City RFPD, having a 30-man volunteer force. This service will not be altered by the annexation.

Reconmendation. Based on its findings the staff reconmends Proposal No. 1198 be denied for the following reasons:

1. The CRAG Plan and Washington County plans are incompatible for this area. The Boundary Commission's position has been against amnexation as a means of resolving land use conflicts. The proposal is outside of the interim growth boundary recently adopted by the CRAG Board.

2. The proposal violates LCDC Goals 3 and 14 . There is no demonstration of a need to annex this land at this time and the territory is not developed nor surrounded by developed land. 


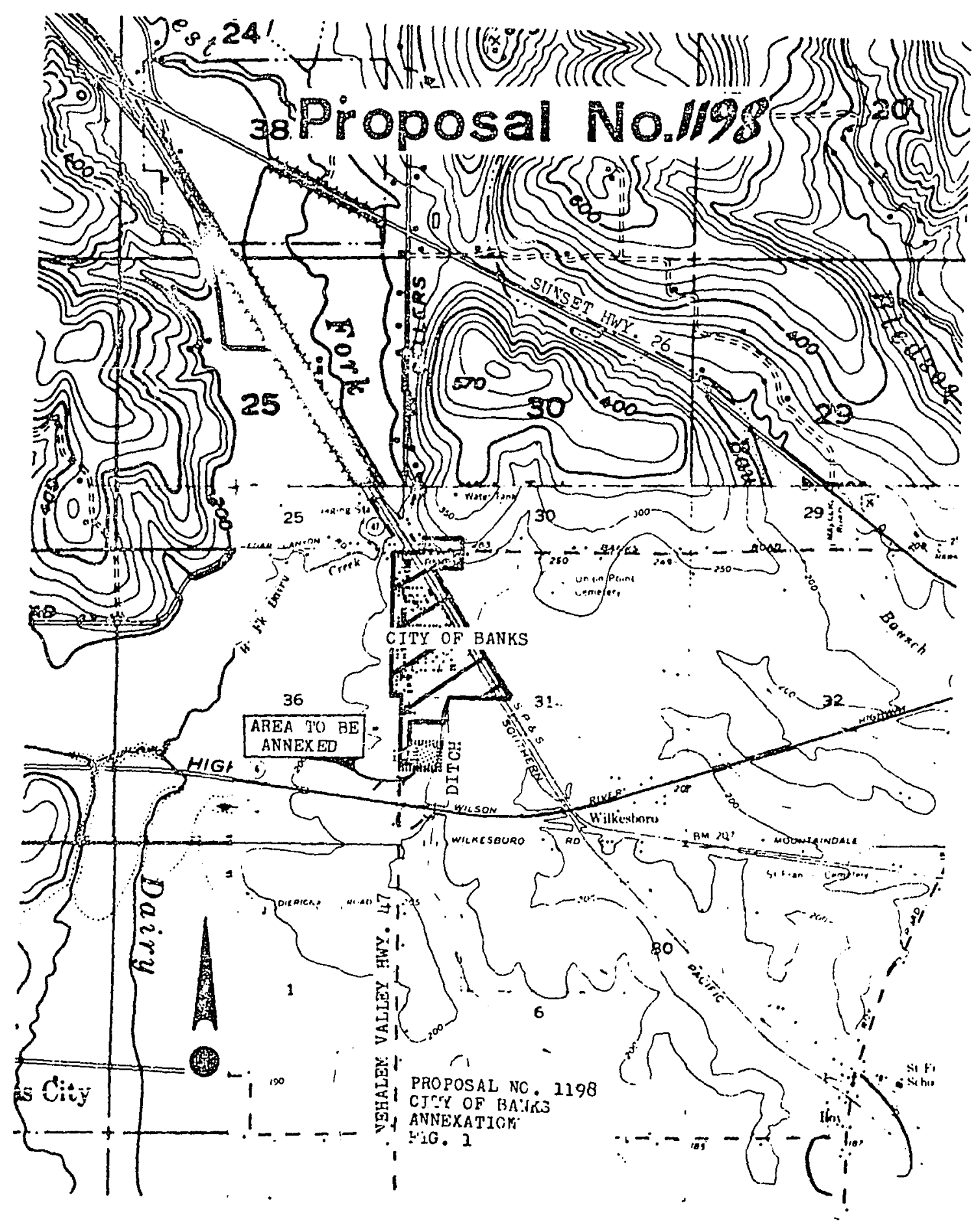


Sin. Blaine Whipple, chairman

Rep. Rod Monroo, Vice-Chairman

Gail Ryder, Administrator Melanle Perko, Assistant

453-D state Capitol $378-5968$

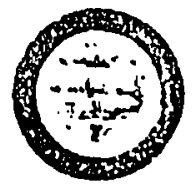

LEGISLATIVE ASSEMBLY JOINT INTERIM TASK FORCES

403 STATE GAPITOL

SALEM. OREGON 97310

(803) $370.05 \pi 5$
Nembers :

Rep. Hary MCCauloy Burrows

Rep. ijoyd KInsey

Sen. Ted Kulongoski

Rep. Glenn Otto

Rep. Wally priestloy

Rep. Al Rlebel

Sen. Frank Roberts

Rep. Glen Whallon

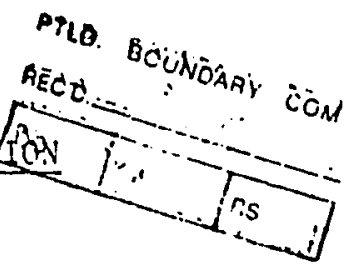

As an overall policy statement relative to boundary commissions, the Task Force affirmed "by and large, boundary commissions are necessary and should be continued".

The Task Force recommends to the 1979 Legislature that:

1. a new boundary commission be created in the Linn-3enton County area.

2. Yamhill County be included in the Marion-Polk County Local Government Boundary Commission.

3. a study be undertaken to create boundary commissions in the Oregon Coastal zone. This might necessitate spliting the Lane County Local Government Boundary Commission at the Coastal Mountain range.

4. a study be undertaken to create a boundary commission in the Jackson-Josepnine County area.

5. a study of redrawing the boundaries of the Portland Netropolitan Area Boundary Commission, as it effects Columia County, be undertaken.

6. the incorrect reference to subsection 3 of ORS $i 99.490$ in ORS 199.464 and 199.495 be corrected to subsection 4.

7. ORS 199 is difficult to follow and read as presently organized and should be reorganized.

8. in ORS $199.440(2)$ the final sentence should read: "No more than two members of a commission shall be engaged in the same kind of business, trade, occupation, or profession.". This would allow housewives to be included in this portion of line law.

9. the present law pretaining to selection of boundary commission members be retained. 


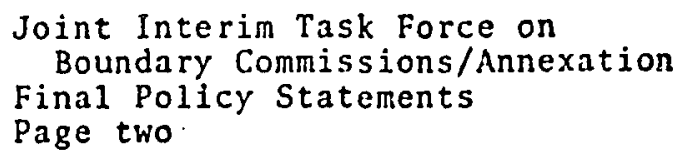

10. there is a need for boundary commission members to file a statement of economic interest with the Ethics Commission.

11. vacancies in commissiun memberilip and commission members abstentions from voting has caused difficulty in acquiring $a$ majority commission vote for action at meetings, resulting in approval of boundary changes by default. This problem should be solved by aijowing a 15 day period of tim. for the Governor to reappoint a new conmission member. If this is not done vithin that period, the remaining members would constitute a full commission until the vacancy is filled.

12. the present law relating to automatic approval of a petition, if the decision of the commission is not filed with the filing agency with 120 days for a major boundary change or reached within 90 days in a minor boundary change, be retained.

13. boundary commission members after declaring a conflict of interest be required to vote on the issue in question.

14. the public notice requirements currently in state law relating to boundary commission actions are adequate.

15. specific reference to the Land Conservation and Development Commission's goals which govern boundary commission decisions should be included in ORS 199.

16. the writ of review provisions for appeal; from boundary commission orders, having been impliedly repealed in part by the Oregon Court of Appeals, be reviewed by the Vrits of Review Sub-Committee of the Law Improvement Committee for their study and recommendation.

17. prior to the formation, annexation, or extra territorial provision of services by a special service district that city approval be required within a probable urban growth boundary, except in boundary commission areas. This would still allow special service districts wishing to extend services beyond the probable urban growth boundary to do so without city approval.

18. consideration be given to the proposal that cities be allowed to annex "developed" land by ordinance, consistent with the plan for the urban growth boundary. Twenty percent. of the voters in the area to be annexed could trigger a single election of the city and area to be annexed which would decide the issue by a single majority vote.

19. consideration be given to the proposal that in boundary commission areas the remonstrance provisions be changed to provide for the single majority vote on proposed annexations. (See 18.) 


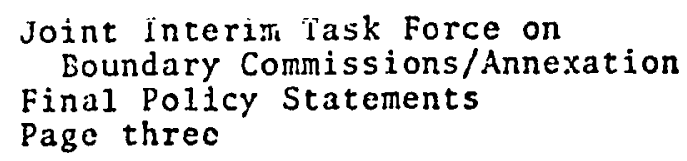

20. consideration of differential tax rates and delayed annexation be given when full service does not follow annexation.

21. a major factor in decisions on boundary changes should be the land planning process.

22. the ministerial procedure among cities, counties and boundary commissions for the annexation of linds into a city should be pursuant to the respective city and counties Comprehensive Plans. The Comprehensive Plan itself reflects the policy while annexation becomes a matter of implementation of land use policy.

23. either annually or biennialiy, the city and county planning commissions sha11 jointly review the need for annexation and formulate recommendations to their respective Council or Commission for consideration.

24. ORS 451.010 should be amended to allow county service districts providing library services to be formed in any county in the state rather than just those within the geographicel jurisdiction of a local government boundary commission.

25. special service districts be provided statutory notice of proposed city annexations of territory within those districts.

26. a study of alternative ways to limit the impact of annexation upon special service districts be undertaken.

$\operatorname{gr} \quad 2 / .7 / 78$

***This is not a final report with full information and background. This is merely the adopted policy statements of the Task Force without explanation. The final report
hopefuliy 


\section{COMMISSIONER INTERVIEN TOPICS}

1. Early leadership.

2. Education and socialization.

3. Substantive policy differences.

4. Procedural policy differences.

5. Ideology.

6. Opinion leaders.

7. Role of the staff.

8. Administrative control of staff.

9. Evaluation of staff performance.

10. Staff as an extension of the Commission. 


\section{PORTLAND BOUNDARY COMAISSIONERS}

PAST AND PRESENT

\author{
Ball, Robert* \\ Blair, Donovan \\ Brandenfels, Mrs. Carl \\ Brown, Richard \\ Casterline, Polly \\ Cease, Dr. Ronald C. \\ Crawford, John \\ Dixon, Brock \\ Eiseman, Frank H.* \\ Federici, Anthony* \\ Ferguson, H. Joseph \\ Frewing, John \\ Gassaway, Carolyn* \\ Gunsul, warilyn \\ Jernstedt, Kenneth E. \\ Lavachek, Iouis C.
}

\author{
Lewis, Ken \\ Iindahl, Keith \\ McDonald, Peter G.* \\ Mckinley, Dr. Charles \\ Merton, Betty \\ Partlow, Fama* \\ Richardson, Campbell \\ Robinette, Jeanne* \\ Slominski, Dr. Paul J。 \\ Solheim, Dorinda* \\ Steele, Carol* \\ Tippins, Jerry \\ Trandom, Walt \\ Voboril, Joe \\ Williams, Marle* \\ Won, Deniece
}

*Denotes current members as of October 24, 1978. 